Review

\title{
Structural chemistry of fluoride and oxofluoride complexes of titanium(IV)
}

\author{
Ruven L. Davidovich ${ }^{\mathrm{a}, *}$, Dmitry V. Marinin ${ }^{\mathrm{a}}$, Vitalie Stavila ${ }^{\mathrm{b}}$, Kenton H. Whitmire ${ }^{\mathrm{c}, *}$ \\ a Institute of Chemistry, Far-Eastern Branch, Russian Academy of Sciences, 159 Prosp. 100- \\ Letiya Vladivostoka, 690022 Vladivostok, Russia \\ ${ }^{\mathrm{b}}$ Energy Nanomaterials, MS-9161, Sandia National Laboratories, 7011 East Avenue, Livermore, \\ CA 94550, USA \\ ${ }^{\mathrm{c}}$ Department of Chemistry, MS-60, Rice University, 6100 Main Street, Houston, TX 77005, USA
}

\section{Table of Contents}

1. Introduction

2. Structures of fluoride complexes of titanium(IV)

2.1. Monomeric structures

2.1.1. Hexafluoridotitanic(IV) acids

2.1.2. Alkali metal and ammonium hexafluoridotitanates(IV)

2.1.3. Hexafluoridotitanates(IV) with mixed monovalent cations

2.1.4. Hexafluoridotitanates(IV) with derivative ammonium cations

2.1.5. Hybrid organic-inorganic hexafluoridotitanates(IV)

2.1.6. Divalent metal hexafluoridotitanates(IV)

2.1.7. Double fluoride complexes of titanium(IV)

2.1.8. Hexafluoridotitanates(IV) with hybrid divalent and trivalent metal cations

2.2. Dimeric structures

2.2.1. Vertex-bridged dimeric fluoridotitanates(IV)

2.2.2. Edge-bridged dimeric fluoridotitanates(IV)

2.3. Oligomeric structures

2.3.1. Fluoridotitanates(IV) with tetrameric complex anions

2.3.2. Fluoridotitanates(IV) with pentameric and octameric complex anions

2.4. Polymeric structures

2.4.1. One-dimensional chain structures

2.4.2. Double chain structures

2.4.3. Layered structure

2.4.4. Column structure

3. Structures of oxo- and hydroxyfluoride complexes of titanium(IV)

3.1. Oxofluoride complexes

3.1.1. Monomeric structures 


\subsubsection{Dimeric structures}

\subsubsection{Chain structures}

3.1.4. Layered structure

3.2. Hydroxyfluoridotitanates(IV)

4. Structures of peroxofluoride complexes of titanium(IV)

4.1. Monomeric structures

4.2. Dimeric structures

\section{Conclusion}

Acknowledgments

Appendix A. Supplementary data

References

\section{A B S T R A C T}

The crystal structures of 119 fluoride and oxofluoride complexes of titanium(IV) (88 fluoride and 31 oxofluoride compounds) published to date have been analyzed and reviewed. Depending on the degree and nature of the association of structural units, the analyzed structures can be divided into monomeric, dimeric, oligomeric, and polymeric, including chain and layered polymeric structures. The manuscript describes the occurrence of various structural motifs, the coordination and geometry of complex anions and cations, as well as the driving forces behind supramolecular crystal assembly. A comprehensive Table is compiled to provide details about composition, values of terminal and bridging Ti-F and Ti-O bonds, as well as the corresponding references. A Table of crystallographic data for the investigated fluoride and oxofluoride complexes of titanium(IV) is presented in the Appendix.

Keywords: titanium(IV), fluoride, oxofluoride, complex, crystal structure, monomeric, oligomeric, polymeric.

\footnotetext{
Abbreviations: L, ligand; av., average; TriMA, $\mathrm{HNMe}_{3}{ }^{+}$, trimethylammonium; $\mathrm{TMA} \mathrm{NMe}_{4}{ }^{+}$, tetramethylammonium; en, ethylenediamine; tren, tris(2-aminoethyl)amine; $\mathrm{C}_{5} \mathrm{H}_{5} \mathrm{~N}$, py, pyridine; $\mathrm{C}_{6} \mathrm{H}_{7} \mathrm{~N}, 2$ picoline; $\mathrm{C}_{7} \mathrm{H}_{9} \mathrm{~N}$, 2,6-lutidine; $\mathrm{C}_{8} \mathrm{H}_{11} \mathrm{~N}, 2$,4,6-collidine; dabco, diazobicyclo[2.2.2] octane; phen, phenantroline; Im, $\mathrm{C}_{3} \mathrm{H}_{4} \mathrm{~N}_{2}$, imidazole; $\mathrm{Ph}$, phenyl; MeCN, acetamide; hmta, hexamethylenetetramine; LP, lone pair; pyz, pyrazine; 4,4'-bipy, 4,4'-bipyridine; 2D, layered structure; $\mathrm{DH}_{2}$, dimethylglyoxime; $\mathrm{NioxH}_{2}, 1,2$-cyclohexanedioxime; $\mathrm{DfgH}_{2}$, diphenylglyoxime; dmf, dimethyl formamide; tu, thiourea; seu, selenurea; TMTSF , $\left(\mathrm{C}_{10} \mathrm{H}_{12} \mathrm{~S}_{4}{ }^{\mathrm{n}+}\right)$, tetramethyltetrathiafulvalene cation; TMTSF, $\left(\mathrm{C}_{10} \mathrm{H}_{12} \mathrm{Se}_{4}{ }^{\mathrm{n}+}\right)$, tetramethyltetraselenafulvalene cation; $\mathrm{C}_{4} \mathrm{H}_{10} \mathrm{~N}_{2}$, piperazine; $\mathrm{C}_{4} \mathrm{H}_{12} \mathrm{~N}_{2}$, 1,4-diaminobutane; dien, diethylenetriamine; $\mathrm{C}_{2} \mathrm{H}_{5} \mathrm{~N}_{5}$, 3,5-diamino-1,2,4-triazole.
} 


\section{Introduction}

This work is a continuation of our ongoing systematic studies of stereochemistry and structural chemistry of group IV and V metal complexes bearing various ligands, including fluoride and oxofluoride complexes [1-6]; specifically, here we analyze and rationalize the structural peculiarities of fluoride and oxofluoride complexes of titanium(IV). These compounds represent an important family of solid materials displaying a wide variety of properties and interesting phenomena. However, despite their remarkable behavior, the structural aspects of fluoride and oxofluoride complexes of Ti(IV) have not been systematically analyzed and discussed in the recent literature.

Fluoride complexes of Ti(IV) can be divided into three groups. Organofluoride complexes of $\mathrm{Ti}(\mathrm{IV})$, which contain Ti-C and/or Ti- $\pi$ bonds as well as Ti-F bond(s), can be assigned to the first group. Most frequently, $\eta^{5}$-cyclopentadienyl acts as a $\pi$-ligand. Numerous organofluoride complexes of titanium(IV) have been synthesized and structurally investigated. A comprehensive survey on preparation, reactivity, and applications of fluoride complexes of $\mathrm{Ti}(\mathrm{IV})$, including organotitanium(IV) fluorides, is presented in review [7]. Binding modes of fluorine in the investigated dimers, rings and chain supramolecular polymeric structures of transition metal organometallic fluorides, including organotitanium(IV) fluorides, were analyzed in detail by Roesky and Haiduc [8]. These authors [8] presented an extensive survey of M-F bond lengths and bond angles in the structures of organometallic fluorides. Organometallic fluorides of $d$ block metals, including Ti(IV), were also discussed by Murphy et al. [9].

The second group of fluoride complexes of $\mathrm{Ti}(\mathrm{IV})$ is composed of $\mathrm{TiF}_{4}$ complexes with coordinated neutral donor ligands of the predominant type $\mathrm{TiF}_{4}(\mathrm{~L})_{2}$. Many fluoride complexes of this type are described in the literature [6]. The chemistry and structure of $p-, d$-, and $f$-block metal fluoride and oxofluoride complexes with neutral donor ligands, including $\mathrm{TiF}_{4}$ complexes with O- and N-donor ligands, were systematized by Benjamin et al. [10].

Fluoride complexes of titanium(IV) of the third group include the so-called anionic fluoride complexes, in which the titanium atom is present as a complex anion. Numerous anionic fluoride complexes of $\mathrm{Ti}(\mathrm{IV})$ with various inorganic and organic cations have been synthesized and structurally studied. However, no reviews on the structural chemistry of Ti(IV) anionic fluoride 
complexes can be found in the recent literature. A review article published almost 30 years ago by Melnik and Cozak [11] discusses in detail the classification and analysis of crystallographic and structural data for titanium coordination compounds obtained by X-ray diffraction, while crystallographic data, Ti-F bond lengths, and F-Ti-F angles were presented for only seven Ti(IV) anionic fluoride complexes known at the time.

To fill this gap, the present review analyzes and generalizes the crystal structures of 119 fluoride and oxofluoride complexes of titanium(IV) (88 fluoride and 31 oxofluoride) investigated by single-crystal X-ray diffraction up to mid-2014. A few crystal structures determined by powder X-ray diffraction with Rietveld refinement have been included in the discussion. Structures of simple oxo- and hydroxyfluoride compounds of Ti(IV) are not considered here. The analyzed crystal structures of fluoride and oxofluoride complexes of titanium(IV) were divided into two groups. First, the structures of fluoride complexes and, thereafter, the structures of oxoand hydroxyfluoride complexes were considered. These groups can be on their turn divided into subgroups including monomeric, dimeric, oligomeric, and polymeric structures.

Systematization of analyzed crystal structures in subgroups, except monomeric ones, was performed while taking into account the unit's association in complex anions, from monomeric to polymeric structures. Among monomeric structures, we first consider the crystal structures with alkali metal and mixed alkali metal cations, as well as ammonium derivatives; thereafter, we examine the hybrid organic-inorganic structures and structures of hexafluoride complexes of Ti(IV) with divalent inorganic metal complex cations. The review contains a comprehensive Table with the composition of the compounds, values of terminal and bridging Ti-F and Ti-O bonds, as well as the corresponding references. A Table of crystallographic data for fluoride and oxofluoride complexes of titanium(IV) (Table S) is presented in Appendix A, Supplementary data.

\section{Structures of fluoride complexes of titanium(IV)}

\subsection{Monomeric structures}

Among structurally investigated fluoride complexes of Ti(IV), monomeric fluoride-bearing isolated $\left[\mathrm{TiF}_{6}\right]^{2-}$ octahedral complex anions are the most common; these compounds have been 
comprehensively characterized by single-crystal X-ray diffraction. The crystal structures of 64 hexafluoride complexes of Ti(IV) with mono- and divalent cations (both inorganic and organic) have been determined to date. In addition, crystal structures of hexafluoridotitanaic(IV) acids and a number of double hexafluoride complexes of titanium(IV) have been studied. In the structures of monomeric fluoride complexes of titanium(IV), the coordination number of Ti(IV) is 6, with an octahedral coordination polyhedron (see Table 1 and references therein [12-98]).

Table 1 here

\subsubsection{Hexafluoridotitanaic(IV) acids}

Hexafluoridotitanaic(IV) acid, $\mathrm{H}_{2} \mathrm{TiF}_{6}$ is a precursor of a large class of fluoride and oxofluoride complexes of titanium(IV). In the course of extraction studies of fluoride complexes of $\mathrm{Ti}(\mathrm{IV})$ from $\mathrm{TiO}_{2}$ solutions in hydrofluoric acid, crystals of the composition $\mathrm{H}_{2} \mathrm{TiF}_{6} \cdot 2 \mathrm{H}_{2} \mathrm{O}$ were isolated and structurally characterized. The $\mathrm{H}_{2} \mathrm{TiF}_{6} \cdot 2 \mathrm{H}_{2} \mathrm{O}$ crystals are trigonal [12] (Table $\mathrm{S}$, Supp. Info) and the structure is composed of oxonium $\mathrm{H}_{3} \mathrm{O}^{+}$cations and trigonally distorted octahedral $\left[\mathrm{TiF}_{6}\right]^{2-}$ complex anions. The crystallographic parameters of $\left(\mathrm{H}_{3} \mathrm{O}\right)_{2}\left[\mathrm{TiF}_{6}\right]$ are rather similar to those of $\mathrm{K}_{2}\left[\mathrm{TiF}_{6}\right]$ [15] (Table $\mathrm{S}$ ), which indicates on an isotypic character of these compounds. The Ti-F bond lengths in the $\left[\mathrm{TiF}_{6}\right]^{2-}$ anion are all equal to $1.86(1) \AA$, while the value of all F-Ti-F trans-angles is $176.5(3)^{\circ}$. In contrast, the values for the cis-angles in the $\mathrm{TiF}_{6}$ polyhedron change from $85.5(3)$ to $92.1(3)^{\circ}$. The $\mathrm{H}_{3} \mathrm{O}^{+}$cations have the characteristic pyramidal structure with $\mathrm{O}-\mathrm{H}-\mathrm{O}$ angles equal to $114(5)^{\mathrm{o}}$. All $\mathrm{F}$ atoms of $\left[\mathrm{TiF}_{6}\right]^{2-}$ anions participate in hydrogen bonds with $\mathrm{H}_{3} \mathrm{O}^{+}$cations $(\mathrm{O}-\mathrm{H} \cdots \mathrm{F}$ 2.96(1) $\AA$ ), thus forming the supramolecular structural motif.

The formation of three crystal hydrates with higher $\mathrm{H}_{2} \mathrm{O}$ has been established: $\mathrm{H}_{2} \mathrm{TiF}_{6} \cdot 3 \mathrm{H}_{2} \mathrm{O}$, $\mathrm{H}_{2} \mathrm{TiF}_{6} \cdot 4 \mathrm{H}_{2} \mathrm{O}$ and $\mathrm{H}_{2} \mathrm{TiF}_{6} \cdot 6 \mathrm{H}_{2} \mathrm{O}$ [13]. The crystal hydrate $\mathrm{H}_{2} \mathrm{TiF}_{6} \cdot 3 \mathrm{H}_{2} \mathrm{O}$ was isolated in the process of determination of the crystal structure of one of the samples of $\mathrm{H}_{2} \mathrm{TiF}_{6} \cdot 4 \mathrm{H}_{2} \mathrm{O}$. Based on crystal structure data, the compounds $\mathrm{H}_{2} \mathrm{TiF}_{6} \cdot 3 \mathrm{H}_{2} \mathrm{O}$ and $\mathrm{H}_{2} \mathrm{TiF}_{6} \cdot 6 \mathrm{H}_{2} \mathrm{O}$ [13] were ionic oxonium salts $\left(\mathrm{H}_{3} \mathrm{O}\right)\left(\mathrm{H}_{5} \mathrm{O}_{2}\right)\left[\mathrm{TiF}_{6}\right]$ and $\left(\mathrm{H}_{5} \mathrm{O}_{2}\right)_{2}\left[\mathrm{TiF}_{6}\right] \cdot 2 \mathrm{H}_{2} \mathrm{O}$. The compound $\mathrm{H}_{2} \mathrm{TiF}_{6} \cdot 6 \mathrm{H}_{2} \mathrm{O}$ $\left(\left(\mathrm{H}_{5} \mathrm{O}_{2}\right)_{2}\left[\mathrm{TiF}_{6}\right] \cdot 2 \mathrm{H}_{2} \mathrm{O}\right)$ is isotypic with $\mathrm{H}_{2} \mathrm{SiF}_{6} \cdot 6 \mathrm{H}_{2} \mathrm{O}$ [99].

The octahedral $\left[\mathrm{TiF}_{6}\right]^{2-}$ anions in the $\left(\mathrm{H}_{3} \mathrm{O}\right)\left(\mathrm{H}_{5} \mathrm{O}_{2}\right)\left[\mathrm{TiF}_{6}\right]$ and $\left(\mathrm{H}_{5} \mathrm{O}_{2}\right)_{2}\left[\mathrm{TiF}_{6}\right] \cdot 2 \mathrm{H}_{2} \mathrm{O}$ structures are significantly distorted, which is caused by participation of virtually all $\mathrm{F}$ atoms of the anions 
in formation of rather strong $\mathrm{O}-\mathrm{H} \cdots \mathrm{F}$ hydrogen bonds. The Ti-F bond lengths in the structure of $\left(\mathrm{H}_{3} \mathrm{O}\right)\left(\mathrm{H}_{5} \mathrm{O}_{2}\right)\left[\mathrm{TiF}_{6}\right]$ range from $1.800(3)$ to $1.903(3) \AA$, whereas in $\left(\mathrm{H}_{5} \mathrm{O}_{2}\right)_{2}\left[\mathrm{TiF}_{6}\right] \cdot 2 \mathrm{H}_{2} \mathrm{O}$ they fall into a narrower range: $1.837(3)$ to $1.877(3) \AA$. In the $\left(\mathrm{H}_{5} \mathrm{O}_{2}\right)^{+}$cations of both structures, oxygen atoms are linked to each other through rather short $\mathrm{O}-\mathrm{H} \cdots \mathrm{O}$ hydrogen bonds with the distances 2.433(3) and 2.438(3) $\AA$, respectively. The $\left(\mathrm{H}_{3} \mathrm{O}\right)^{+}$and $\left(\mathrm{H}_{5} \mathrm{O}_{2}\right)^{+}$cations form strong $\mathrm{O}-\mathrm{H} \cdots \mathrm{F}$ hydrogen bonds with $\mathrm{O} \cdots \mathrm{F}$ distances in the range 2.534(1)-2.736(3) $\AA$. Through these bonds, the cations and complex $\left[\mathrm{TiF}_{6}\right]^{2-}$ anions are linked into three-dimensional structures.

\subsubsection{Alkali metal and ammonium hexafluoridotitanates(IV)}

The structural chemistry of fluoride complexes of titanium(IV) of general formula $\mathrm{M}_{2}{ }_{2} \mathrm{TiF}_{6}$ ( $\mathrm{M}^{\mathrm{I}}$-alkali metal or ammonium) has been explored by several groups [100-102]. Based on the structural peculiarities, $\mathrm{M}_{2}^{\mathrm{I}} \mathrm{TiF}_{6}$ complexes were divided into two groups. The first group includes $\mathrm{M}_{2}^{\mathrm{I}} \mathrm{TiF}_{6}$ with relatively large outer-sphere cations $\left(\mathrm{M}^{\mathrm{I}}=\mathrm{K}^{+}, \mathrm{Rb}^{+}, \mathrm{Cs}^{+}, \mathrm{NH}_{4}^{+}, \mathrm{Tl}^{+}\right)$, while the second group contains smaller $\mathrm{Li}^{+}$and $\mathrm{Na}^{+}$cations.

According to Cox and Sharp [100], $\mathrm{M}_{2}^{\mathrm{I}} \mathrm{TiF}_{6}$ fluoride complexes with large monovalent cations crystallize in three forms: trigonal (structural type $\mathrm{K}_{2} \mathrm{GeF}_{6}$ ) [103], hexagonal (structural type $\mathrm{K}_{2} \mathrm{MnF}_{6}$ ) [104], and cubic (structural type $\mathrm{K}_{2} \mathrm{PtCl}_{6}$ ) [105]. The crystal structures of these complexes are built according to the principle of close-packing of $\mathrm{M}^{+}$and $\mathrm{F}^{-}$ions. The $\mathrm{Ti}^{4+}$ ions are located in the octahedral voids. The basic units of all $\mathrm{M}_{2}^{\mathrm{I}} \mathrm{TiF}_{6}$ structures $\left(\mathrm{M}^{\mathrm{I}}=\mathrm{K}^{+}, \mathrm{Rb}^{+}, \mathrm{Cs}^{+}\right.$, $\mathrm{NH}_{4}{ }^{+}, \mathrm{Tl}^{+}$) are parallel layer-triplets $\mathrm{M}^{\mathrm{I}}-\mathrm{TiF}_{6}-\mathrm{M}^{\mathrm{I}}$. A close-packed assembly of atoms in these structures is realized through consecutive displacement of $\mathrm{MF}_{3}$ triple layers, so that each second triple layer in the trigonal form, each third triple layer in the hexagonal form, and each fourth triple layer in the cubic form have identical positions with respect to the first triple layer. Thus, the sequence of triple layers is $A A A$ for the trigonal form, $A B A B$ for the hexagonal form, and $A B C A B C$ for the cubic form [101]. Formation of polymorphous $\mathrm{M}_{2}^{\mathrm{I}} \mathrm{TiF}_{6}$ forms was established at heating these complexes in the temperature range $275-350{ }^{\circ} \mathrm{C}[100]$.

At room temperature, $\mathrm{M}_{2}^{\mathrm{I}} \mathrm{TiF}_{6}\left(\mathrm{M}^{\mathrm{I}}=\mathrm{K}^{+}, \mathrm{Rb}^{+}, \mathrm{Cs}^{+}, \mathrm{NH}_{4}{ }^{+}, \mathrm{Tl}^{+}\right)$complexes crystallize in the trigonal symmetry [100] and are isostructural with $\mathrm{K}_{2} \mathrm{GeF}_{6}$ [103]. X-ray diffraction studies on single crystals corroborated the data obtained in [100]. The crystal structure of the trigonal modification of $\mathrm{K}_{2} \mathrm{TiF}_{6}[14]$ was assigned to the $\mathrm{K}_{2} \mathrm{GeF}_{6}$ structural type. The unit cell dimensions 
for $\mathrm{K}_{2}\left[\mathrm{TiF}_{6}\right]$ (Table $\mathrm{S}$ ) are in good agreement with [100]. The Ti atoms surrounded by $6 \mathrm{~F}$ atoms form slightly distorted octahedral groups with the Ti-F distance $1.91 \AA$. Each $\mathrm{K}$ atom in the structure is linked to 12 fluorine atoms. The $\mathrm{K}_{2}\left[\mathrm{TiF}_{6}\right]$ crystal structure was re-determined by Göbel [15]. The lattice parameters $\mathrm{K}_{2}\left[\mathrm{TiF}_{6}\right]$ (Table $\mathrm{S}$ ) are in agreement with earlier results [14, 100]. The $\mathrm{TiF}_{6}$ coordination polyhedron comprises a slightly distorted octahedron compressed along the $c$ axis. The coordination polyhedron around the $\mathrm{K}^{+}$ion is a slightly distorted anticuboctahedron. The $a v$. K-F distance is 2.91(8) $\AA$.

The crystal structure of $\mathrm{K}_{2}(\mathrm{HF})\left[\mathrm{TiF}_{6}\right]$ [16] is composed of octahedral $\left[\mathrm{TiF}_{6}\right]^{2-}$ complex anions, two crystallographically independent $\mathrm{K}^{+}$cations, and solvate $\mathrm{HF}$ molecules. The structure comprises a cubic close-packed array of $\left[\mathrm{TiF}_{6}\right]^{2-}$ anions with $\mathrm{K}(1)^{+}$cations in $T_{\mathrm{d}}$ holes and $\mathrm{K}(2)^{+}$cations in $O_{\mathrm{h}}$ holes. The Ti-F bond lengths in $\left[\mathrm{TiF}_{6}\right]^{2-}$ anions range from $1.842(3)$ to 1.884(4) $\AA$. The $\mathrm{K}(1)^{+}$and $\mathrm{K}(2)^{+}$cations are coordinated with 12 and $9 \mathrm{~F}$ atoms, respectively. The $\mathrm{K} \cdots \mathrm{F}$ distances are on average longer for $\mathrm{K}(1)^{+}$than for $\mathrm{K}(2)^{+}$. The $\mathrm{K}(1)^{+}$coordination sphere is an idealized cube and the coordination sphere of the $\mathrm{K}(2)^{+}$cation is a tri-capped trigonal prism. Five of six $\mathrm{F}$ atoms of the $\left[\mathrm{TiF}_{6}\right]^{2-}$ anions bridge three or four $\mathrm{K}^{+}$cations. The $\mathrm{HF}$ molecule forms rather strong F-H $\cdots$ F hydrogen bond with the F $\cdots$ F distance equal to 2.533(6) $\AA$. Electrostatic interactions between cations and anions assemble the structural units of the crystal into a three-dimensional network. Crystals of $\mathrm{K}_{2}(\mathrm{HF}) \mathrm{TiF}_{6}$ rapidly lose $\mathrm{HF}$ in an air-free environment at $25^{\circ} \mathrm{C}$ with formation of the trigonal polymorph of $\mathrm{K}_{2} \mathrm{TiF}_{6}$ [15].

In the $\mathrm{M}_{2}^{\mathrm{I}} \mathrm{TiF}_{6}\left(\mathrm{M}^{\mathrm{I}}=\mathrm{K}^{+}, \mathrm{Rb}^{+}, \mathrm{Cs}^{+}, \mathrm{NH}_{4}{ }^{+}, \mathrm{Tl}^{+}\right)$isostructural series, the crystal structures of $\mathrm{Cs}_{2} \mathrm{TiF}_{6}$ and $\left(\mathrm{NH}_{4}\right)_{2} \mathrm{TiF}_{6}$ were determined using the single-crystal X-ray diffraction method, while that of $\mathrm{Tl}_{2} \mathrm{TiF}_{6}$ was determined by powder X-ray diffraction with Rietveld refinement. The crystal structure of $\mathrm{Cs}_{2}\left[\mathrm{TiF}_{6}\right]$ [17], just like that of $\mathrm{K}_{2}\left[\mathrm{TiF}_{6}\right]$ [15], belongs to the structural type of $\mathrm{K}_{2} \mathrm{GeF}_{6}$. The unit cell parameters of the $\mathrm{Cs}_{2}\left[\mathrm{TiF}_{6}\right]$ structure are somewhat larger than respective parameters of the $\mathrm{K}_{2}\left[\mathrm{TiF}_{6}\right]$ unit cell (Table $\mathrm{S}$ ), which is caused by larger size of the $\mathrm{Cs}^{+}$cations. The structure of $\mathrm{Cs}_{2}\left[\mathrm{TiF}_{6}\right]$ is composed of $\mathrm{CsF}_{3}$ layers, in whose octahedral voids $\mathrm{Ti}^{4+}$ cations are located. Each $\mathrm{Ti}^{4+}$ ion is surrounded by six $\mathrm{F}$ atoms in a regular octahedron. All Ti-F bond lengths are 1.868(2) Å. A similar Ti-F distance (1.8605(6) $\AA$ ) was found for $\mathrm{K}_{2}\left[\mathrm{TiF}_{6}\right]$ [15] (Table 1). The environment of $\mathrm{Cs}$ atoms is composed of $12 \mathrm{~F}$ atoms with bond lengths in the range 3.1549(7)-3.287(2) А. 
The $\left(\mathrm{NH}_{4}\right)_{2}\left[\mathrm{TiF}_{6}\right]$ crystal structure was studied at two temperatures: 293 and $153 \mathrm{~K}$ [18]. As was confirmed, the $\left(\mathrm{NH}_{4}\right)_{2}\left[\mathrm{TiF}_{6}\right]$ structure has trigonal symmetry $\left(\mathrm{K}_{2} \mathrm{GeF}_{6}\right.$ structural type). The unit cell parameters at $153 \mathrm{~K}$ are somewhat smaller than the respective ones at $293 \mathrm{~K}$ (Table S). In the octahedral $\left[\mathrm{TiF}_{6}\right]^{2-}$ complex anion, the symmetry-equivalent Ti-F bond lengths at $153 \mathrm{~K}$ are also somewhat smaller $(1.857(1) \AA)$ than at room temperature $(1.864(1) \AA)$. At $153 \mathrm{~K}$, the $\mathrm{NH}_{4}{ }^{+}$-cations $\mathrm{H}$ atoms are ordered, but show a large anisotropic thermal motion. At room temperature, this motion is much greater, and the $\mathrm{NH}_{4}{ }^{+}$cations are positioned statistically. The disorder of $\mathrm{NH}_{4}{ }^{+}$cations in $\left(\mathrm{NH}_{4}\right)_{2}\left[\mathrm{TiF}_{6}\right]$ is similar to that proposed for the cubic form of $\left(\mathrm{NH}_{4}\right)_{2} \mathrm{SiF}_{6}$ [106] and quite different from that found in the trigonal form of $\left(\mathrm{NH}_{4}\right)_{2} \mathrm{SiF}_{6}$ [107].

The $\mathrm{Tl}_{2} \mathrm{TiF}_{6}$ crystal structure [19] determined from powder X-ray diffraction data and refined by Rietveld analysis [108] is also isotypic with $\mathrm{K}_{2} \mathrm{GeF}_{6}$. The Rietveld refinement of the $\mathrm{Tl}_{2} \mathrm{TiF}_{6}$ structure was performed using initial positional parameters from the $\mathrm{K}_{2} \mathrm{GeF}_{6}$ structure [103]. A good agreement between the observed and calculated data was established. The crystal structure of $\mathrm{Tl}_{2} \mathrm{TiF}_{6}$ is composed of octahedral $\mathrm{TiF}_{6}$ groups linked by $\mathrm{Tl}$ atoms into a threedimensional network. The structure can be also described as a hexagonal $(A B A B)$ packing of puckered layers formed by $\mathrm{F}$ and $\mathrm{Tl}$ atoms. The Ti atoms occupy one-eighth of the octahedral holes formed by $\mathrm{F}$ atoms. The $\mathrm{Tl}$ atoms are anti-cuboctahedrally coordinated by twelve $\mathrm{F}$ atoms with relatively long Tl-F distances in the range 2.86-3.26 $\AA$. The crystal structure of $\mathrm{Rb}_{2} \mathrm{TiF}_{6}$ has not been established yet. The powder X-ray diffraction data of $\mathrm{Rb}_{2} \mathrm{TiF}_{6}[102,109]$ corroborated that $\mathrm{Rb}_{2} \mathrm{TiF}_{6}$ belonged to the isostructural $\mathrm{M}_{2}^{\mathrm{I}} \mathrm{TiF}_{6}$ series.

Unlike crystal structures of the isostructural $\mathrm{M}_{2}^{\mathrm{I}} \mathrm{TiF}_{6}$ series with large monovalent cations built from alternating close-packed $\mathrm{MF}_{3}$ layers, $\mathrm{M}_{2}^{\mathrm{I}} \mathrm{TiF}_{6}$ structures with relatively small $\mathrm{Li}^{+}$and $\mathrm{Na}^{+}$cations are formed by close-packed $\mathrm{F}^{-}$ions with cations located in octahedral voids. The three-dimensional network structure is composed of $\mathrm{MF}_{6}$ and $\mathrm{TiF}_{6}$ octahedra linked through common edges and vertices. The crystal structures of $\mathrm{Li}_{2} \mathrm{TiF}_{6}$ [20], $\mathrm{Li}_{2} \mathrm{TiF}_{6} \cdot 2 \mathrm{H}_{2} \mathrm{O}$ [21], and $\mathrm{Na}_{2} \mathrm{TiF}_{6}$ [22] were determined. The $\mathrm{Li}_{2} \mathrm{TiF}_{6}$ crystals belong to the trirutile structural type [110]. The $\mathrm{Li}_{2} \mathrm{TiF}_{6}$ structure was resolved from the powder X-ray data [20]. The compound crystallizes with tetragonal symmetry and $Z=2$ (Table $S$ ). The $\mathrm{Ti}$ atoms are surrounded by six $\mathrm{F}$ atoms forming $\mathrm{TiF}_{6}$ polyhedra linked by $\mathrm{Li}$ atoms. The nearest neighbors of the $\mathrm{F}$ atom include one $\mathrm{Ti}$ atom and two $\mathrm{Li}$ atoms. The structure of $\mathrm{Li}_{2} \mathrm{TiF}_{6}$ was not described in detail. 
The crystal structure of $\mathrm{Li}_{2} \mathrm{TiF}_{6} \cdot 2 \mathrm{H}_{2} \mathrm{O}$ was solved using the Weissenberg method [21]. The structure is composed of $\mathrm{Li}^{+}$cations, $\left[\mathrm{TiF}_{6}\right]^{2-}$ anions, and lattice $\mathrm{H}_{2} \mathrm{O}$ molecules. The $\mathrm{Li}_{2} \mathrm{TiF}_{6} \cdot 2 \mathrm{H}_{2} \mathrm{O}$ structure consists of hexagonal close-packed array of fluorine atoms and water molecules with lithium and titanium atoms in distorted octahedral holes. The $\mathrm{Li}^{+}$cations form rows of edge-sharing $\mathrm{LiF}_{4}\left(\mathrm{OH}_{2}\right)_{2}$ octahedra running along the $b$ axis. The $\left[\mathrm{TiF}_{6}\right]^{2-}$ octahedral anions are tetragonally distorted. The lengths of Ti-F bonds differ significantly ranging from 1.903(3) to $1.968(4) \AA$. The $\mathrm{Li}-\mathrm{F}(1)$ and $\mathrm{Li}-\mathrm{F}(2)$ bond lengths range between $2.160(3)$ and 2.186(3) $\AA$, whereas the distance from the $\mathrm{Li}$ atom to the $\mathrm{O}$ atom of the $\mathrm{H}_{2} \mathrm{O}$ molecule is 2.046(4) $\AA$. A three-dimensional network of the structure is formed by linking $\mathrm{LiF}_{4}\left(\mathrm{OH}_{2}\right)_{2}$ rows with $\left[\mathrm{TiF}_{6}\right]^{2}$ octahedra.

According to [111], $\mathrm{Na}_{2} \mathrm{TiF}_{6}$ crystallizes in the hexagonal symmetry and is isomorphic to $\mathrm{Na}_{2} \mathrm{SiF}_{6}, \mathrm{Na}_{2} \mathrm{GeF}_{6}$, and $\mathrm{Na}_{2} \mathrm{MnF}_{6}$. The crystal structure of $\mathrm{Na}_{2} \mathrm{TiF}_{6}$ is related to the $\mathrm{Na}_{2} \mathrm{SiF}_{6}$ structural type [112]. The structure of $\mathrm{Na}_{2} \mathrm{TiF}_{6}$ was studied using the powder and twinned crystals methods [22]. The intensity measurements and accurate determination of the space group were carried out with twinned crystals. The crystal structure of $\mathrm{Na}_{2} \mathrm{TiF}_{6}$ contains two independent slightly distorted octahedral complex anions $\left[\mathrm{TiF}_{6}\right]^{2-}$ with average $\mathrm{Ti}-\mathrm{F}$ distances equal to $1.70(1)$ and $1.75(1) \AA$. There are two crystallographic types of $\mathrm{Na}^{+}$cations occupying octahedral voids in the structure, each surrounded by six $\mathrm{F}$ atoms. The $a v$. Na-F bond lengths in the two cations are 2.29(1) and 2.36(1) $\AA$. Ionic interactions link $\mathrm{Na}^{+}$cations and $\left[\mathrm{TiF}_{6}\right]^{2-}$ anions into a three-dimensional network.

\subsubsection{Hexafluoridotitanates(IV) with mixed monovalent cations}

The crystal structures of a series of hexafluoridotitanates(IV) with mixed monovalent cations of alkali metals and ammonium have been determined. Similar to $\mathrm{M}_{2} \mathrm{TiF}_{6}$ structures, the $\mathrm{MM}^{\prime}\left[\mathrm{TiF}_{6}\right]\left(\mathrm{M}=\mathrm{Li}^{+}, \mathrm{Na}^{+} ; \mathrm{M}^{\prime}=\mathrm{Rb}^{+}, \mathrm{Cs}^{+}, \mathrm{NH}_{4}{ }^{+}\right)$structures display a hexacoordinated $\mathrm{Ti}$ atom, and the $\mathrm{TiF}_{6}$ coordination polyhedron is a slightly distorted octahedron. The $\mathrm{MM}^{\prime}\left[\mathrm{TiF}_{6}\right]$ crystal structures (Table 1) differ significantly from that of $\mathrm{M}_{2} \mathrm{TiF}_{6}$ built from alternating close-packed $\mathrm{MF}_{3}$ layers. The $\mathrm{MM}^{\prime}\left[\mathrm{TiF}_{6}\right]$ structure is based on a three-dimensional framework composed of $\mathrm{M}$ and Ti atoms polyhedra linked through common edges and vertices. 
The compounds $\mathrm{NaRb}\left[\mathrm{TiF}_{6}\right.$ ], $\left.\mathrm{NaCs} \mathrm{TiF}_{6}\right]$ [23], $\mathrm{Na}\left(\mathrm{NH}_{4}\right)$ [ $\left.\mathrm{TiF}_{6}\right]$ [24], and $\mathrm{Li}\left(\mathrm{NH}_{4}\right)\left[\mathrm{TiF}_{6}\right]$ [25] have an identical framework crystal structure. In the $\mathrm{NaM}^{\prime}\left[\mathrm{TiF}_{6}\right]\left(\mathrm{M}^{\prime}=\mathrm{Rb}^{+}, \mathrm{Cs}^{+}, \mathrm{NH}_{4}^{+}\right)$and $\mathrm{Li}\left(\mathrm{NH}_{4}\right)\left[\mathrm{TiF}_{6}\right]$ structures, $\mathrm{Na}^{+}$(and $\mathrm{Li}^{+}$, respectively) and $\mathrm{Ti}$ atoms form slightly distorted octahedral $\mathrm{NaF}_{6}$ and $\mathrm{TiF}_{6}$ polyhedra. In $\mathrm{TiF}_{6}$ octahedra, the Ti-F bond lengths are virtually equal to each other (Table 1). The average Na-F and Li-F bond length are 2.289(2) and 2.042(3) $\AA$, respectively.

In the $\mathrm{NaM}^{\prime}\left[\mathrm{TiF}_{6}\right]\left(\mathrm{M}^{\prime}=\mathrm{Rb}^{+}, \mathrm{Cs}^{+}, \mathrm{NH}_{4}^{+}\right)$and $\mathrm{Li}\left(\mathrm{NH}_{4}\right)\left[\mathrm{TiF}_{6}\right]$ structures, $\mathrm{NaF}_{6}\left(\mathrm{LiF}_{6}\right)$ and $\mathrm{TiF}_{6}$ octahedra form dimers through linking by common F-F edge. The dimers are linked through common vertices into zigzag-like bands forming the framework. Large outer-sphere $\mathrm{Rb}^{+}, \mathrm{Cs}^{+}$, and $\mathrm{NH}_{4}{ }^{+}$cations are located in the framework voids. In the $\mathrm{NaRb}\left[\mathrm{TiF}_{6}\right]$ structure, the two independent $\mathrm{Rb}$ atoms are each surrounded by ten $\mathrm{F}$ atoms and form polyhedra of irregular shapes. The $a v$. Rb-F distances are equal to 3.051(5) and 3.109(6) $\AA$, respectively. The Cs atoms in the structure of $\mathrm{NaCs}_{2}\left[\mathrm{TiF}_{6}\right]$ also form a ten-vertex polyhedron of an irregular shape with Cs-F distances ranging from 3.014(3) to 3.510(5) ^ (av. $3.236 \AA$ ).

The $\mathrm{LiCs}_{\mathrm{TiF}}$ ] [17] compound, just like $\mathrm{NaM}^{\prime}\left[\mathrm{TiF}_{6}\right]\left(\mathrm{M}^{\prime}=\mathrm{Rb}^{+}, \mathrm{Cs}^{+}, \mathrm{NH}_{4}{ }^{+}\right)$and $\mathrm{Li}\left(\mathrm{NH}_{4}\right)\left[\mathrm{TiF}_{6}\right]$, has a framework structure, whose formation differs significantly from that of the framework in the structures of $\mathrm{NaM}^{\prime}\left[\mathrm{TiF}_{6}\right]$ and $\mathrm{Li}\left(\mathrm{NH}_{4}\right)\left[\mathrm{TiF}_{6}\right]$. Six $\mathrm{F}$ atoms located at distances

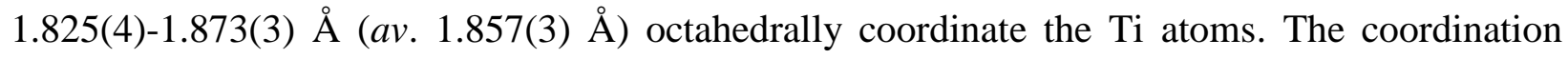
polyhedron of the Li atom is a slightly distorted tetragonal pyramid with $\mathrm{F}$ atoms in vertices. The Li-F bond lengths range from 1.86(1) to 2.24(1) $\AA$ (av. 2.00(1) $\AA$ ). The $\mathrm{TiF}_{6}$ octahedra and $\mathrm{LiF}_{5}$ polyhedra are linked into $\mathrm{LiTiF}_{9}$ dimers though a common F-F edge. Two dimers located around the inversion center and linked to each other through common edges form tetranuclear groups, which serve as the structural unit of the three-dimensional framework. Each tetranuclear group is linked through six adjacent ones, thus forming a three-dimensional framework. The framework has channels composed of $\mathrm{Cs}^{+}$cations that additionally bind structural units along the [100] and [001] crystallographic directions. The Cs $\cdots$ F distances range from 2.958(4) to 3.206(4) $\AA$.

The crystal structure of $\mathrm{LiNa}_{3}\left(\mathrm{TiF}_{6}\right)_{2}[26]$ is composed of alternating layers formed by edgeshared coordination polyhedra of $\mathrm{Ti}$ and $\mathrm{Na}(1)$ atoms. The structure contains two types of crystallographically independent $\mathrm{Na}$ cations: $\mathrm{Na}(1)^{+}$and $\mathrm{Na}(2)^{+}$. The coordination polyhedra of $\mathrm{Ti}$ atoms comprise slightly distorted $\mathrm{TiF}_{6}$ octahedra. The $\mathrm{Na}(1) \mathrm{F}_{6}$ polyhedra also have the 
octahedral structure. The $\mathrm{Na}(1)$-F bond lengths range from $2.252(4)$ to $2.415(5) \AA(a v .2 .348(4)$ $\AA$ ). The $\mathrm{TiF}_{6}$ and $\mathrm{Na}(1) \mathrm{F}_{6}$ polyhedra linked through common edge form $\mathrm{TiNa}(1) \mathrm{F}_{10}$ dimers. Each dimer shares eight vertices with four adjacent ones, thus forming an infinite layer. The coordination polyhedron of the $\mathrm{Li}$ atom is a $\mathrm{LiF}_{4}$ tetrahedron $\left(\mathrm{d}_{\mathrm{Li}-\mathrm{F}}=1.898(3) \AA\right)$. The $\mathrm{Na}(2)$ atoms surrounded by eight $\mathrm{F}$ atoms form polyhedra of complex shapes. The $\mathrm{Na}(2)-\mathrm{F}$ bond lengths are in the range 2.293(3)-2.585(3) $\AA$ ( $a v .2 .439(3) \AA$ ). The $\mathrm{Li}^{+}$and $\mathrm{Na}(2)^{+}$cations surrounded by $\mathrm{F}$ atoms link the layers into a three-dimensional network.

\subsubsection{Hexafluoridotitanates(IV) with derivative ammonium cations}

The compounds of general formula $\mathrm{A}_{2} \mathrm{BX}_{6}$, in which $\mathrm{A}^{+}$and $\mathrm{B}^{4+}$ are cations and $\mathrm{X}$ is halogen, with large $\mathrm{A}^{+}$cations, $\mathrm{NH}_{4}{ }^{+}$derivatives, for instance trimethylammonium $\left(\mathrm{HNMe}_{3}{ }^{+}\right)$ and tetramethylammonium $\left(\mathrm{NMe}_{4}{ }^{+}\right)$(hereinafter referred to as $\mathrm{TriMA}^{+}$and $\mathrm{TMA}^{+}$, respectively), have the structures assigned to three types: cubic, cubic derivative, or pseudo-cubic derivative. The first type includes the compound (TMA) $2\left[\mathrm{PtCl}_{6}\right](F m \overline{3} m)$ [113], the second type - the compound (TriMA) $)_{2}\left[\mathrm{SnCl}_{6}\right](F d \overline{3} c)$ [114], and the third type - the compound (TMA) $)_{2}\left[\mathrm{PtF}_{6}\right]$ $(I 4 / m)[115]$ or $\left(\mathrm{TMA}_{2}\left[\mathrm{OsF}_{6}\right](R \overline{3})\right.$ [116]. To obtain information on the structures of $(\mathrm{TMA})_{2}\left[\mathrm{BX}_{6}\right]$ compounds with the symmetry different from $F m \overline{3} m$, the crystal structure of $(\mathrm{TMA})_{2}\left[\mathrm{TiF}_{6}\right]$ was investigated [27]. At room temperature, the compound has rhombohedral symmetry and is isostructural with $\left(\mathrm{TMA}_{2}\left[\mathrm{OsF}_{6}\right][116]\right.$. The crystal structure of $(\mathrm{TMA})_{2}\left[\mathrm{TiF}_{6}\right]$ was also studied [28] and is composed of virtually regular $\mathrm{TiF}_{6}$ octahedra and tetrahedral $\mathrm{TMA}^{+}$ cations. Cis-F-Ti-F angles differ only negligibly from $90^{\circ}$.

Since $(\mathrm{TMA})_{2}\left[\mathrm{PtF}_{6}\right]$ and $\left(\mathrm{TMA}_{2}\left[\mathrm{OsF}_{6}\right]\right.$ derivatives undergo a phase transition to a cubic high temperature phase around $160{ }^{\circ} \mathrm{C}$, Göbel et al. [27] hypothesized that (TMA) $\left[\mathrm{TiF}_{6}\right]$ should display a similar phase transition upon heating. Studies of the crystal structure of $(\mathrm{TMA})_{2}\left[\mathrm{TiF}_{6}\right]$ by the single-crystal X-ray diffraction method in the temperature range between -173 and $180{ }^{\circ} \mathrm{C}$ [29] confirmed this hypothesis. In the temperature range between 140 and $147{ }^{\circ} \mathrm{C},(\mathrm{TMA})_{2}\left[\mathrm{TiF}_{6}\right]$ 
undergoes a phase transition from rhombohedral room temperature phase $(R \overline{3})$ into hightemperature cubic phase $(F m \overline{3} m)$ (Table $S)$.

The crystal structure of $\left(\mathrm{NMe}_{4}\right)\left[\mathrm{Ti}(2)\left(\mathrm{H}_{2} \mathrm{O}\right)_{4} \mathrm{~F}_{2}\right]\left[\mathrm{Ti}(1) \mathrm{F}_{6}\right] \mathrm{H}_{2} \mathrm{O}$ is composed of $\mathrm{NMe}_{4}^{+}$ cations, complex $\left[\mathrm{Ti}(2)\left(\mathrm{H}_{2} \mathrm{O}\right)_{4} \mathrm{~F}_{2}\right]^{+}$cations containing $\mathrm{Ti}(\mathrm{III})$ atoms, complex anions $\left[\mathrm{Ti}(1) \mathrm{F}_{6}\right]^{2-}$, and lattice $\mathrm{H}_{2} \mathrm{O}$ molecules (Fig. 1) [30]. In the octahedral [Ti(2) $\left.\left(\mathrm{H}_{2} \mathrm{O}\right)_{4} \mathrm{~F}_{2}\right]^{+}$cation, the $\mathrm{F}$ atoms are located in the trans-positions relative to each other. The $\operatorname{Ti}(2)-\mathrm{F}(1)$ and $\operatorname{Ti}(2)-\mathrm{F}(2)$ bond lengths differ significantly (1.828(3) and 1.930(3) $\AA$, respectively). This is caused by participation of $\mathrm{F}(2)$ in strong hydrogen bonds: $\mathrm{O}(2) \cdots \mathrm{F}(2)(2.65 \AA)$. The $a v$. Ti(2)- $\mathrm{OH}_{2}$ bond length in $\left[\mathrm{Ti}(2)\left(\mathrm{H}_{2} \mathrm{O}\right)_{4} \mathrm{~F}_{2}\right]^{+}$cation is 2.087(3) $\AA$.

Fig. 1 here

The regular octahedral complex anion $\left[\mathrm{TiF}_{6}\right]^{2-}$ displays the shortest Ti-F bond distances in the structures of hexafluoridotitanates(IV) with isolated octahedral $\left[\mathrm{TiF}_{6}\right]^{2-}$ complex anions studied to date (Table 1). Complex $\left[\mathrm{Ti}\left(\mathrm{H}_{2} \mathrm{O}\right)_{4} \mathrm{~F}_{2}\right]^{+}$cations, $\left[\mathrm{TiF}_{6}\right]^{2-}$ anions and crystallization $\mathrm{H}_{2} \mathrm{O}$ molecules link through a branched system of hydrogen bonds to form hydrogen-bonded layers along the $c$ direction with $\mathrm{NMe}_{4}{ }^{+}$cations between them.

The structure of monoclinic crystals $\left(\mathrm{NH}_{3} \mathrm{OH}\right)_{2}\left[\mathrm{TiF}_{6}\right] 2 \mathrm{H}_{2} \mathrm{O}$ [31] is build up by octahedral [TiF $\left.]_{6}\right]^{2-}$ complex anions, $\mathrm{NH}_{3} \mathrm{OH}^{+}$cations, and lattice $\mathrm{H}_{2} \mathrm{O}$ molecules. The $\left[\mathrm{TiF}_{6}\right]^{2-}$ octahedra are substantially distorted; the Ti-F bond lengths are in the range 1.8384(7)-1.8460(7) $\AA$. The $\mathrm{NH}_{3} \mathrm{OH}^{+}$cations and $\mathrm{H}_{2} \mathrm{O}$ molecules form hydrogen bonds with the $\mathrm{F}$ atoms as well as each other. The strongest hydrogen bond is formed by the cation $\mathrm{OH}$-group with the $\mathrm{H}_{2} \mathrm{O}$ molecule oxygen atom $(\mathrm{O} \cdots \mathrm{O}(1) 2.6805(12) \AA)$. The $\left[\mathrm{TiF}_{6}\right]^{2-}$ anions, $\mathrm{NH}_{3} \mathrm{OH}^{+}$cations, and $\mathrm{H}_{2} \mathrm{O}$ molecules are linked by hydrogen bonds and form a three-dimensional framework.

The structure of monoclinic $\left[\mathrm{N}\left(n-\mathrm{C}_{16} \mathrm{H}_{33}\right) \mathrm{Me}_{3}\right]_{2}\left[\mathrm{TiF}_{6}\right] \cdot 2 \mathrm{H}_{2} \mathrm{O}$ [32] crystals consists of large cetyltrimethylammonium cations, $\left[\mathrm{N}\left(n-\mathrm{C}_{16} \mathrm{H}_{33}\right) \mathrm{Me}_{3}\right]^{+}, \quad$ complex anions $\left[\mathrm{TiF}_{6}\right]^{2-}$, and crystallization $\mathrm{H}_{2} \mathrm{O}$ molecules. The Ti atoms located on two-fold rotation axis and surrounded by six $\mathrm{F}$ atoms with Ti-F distances equal to $1.836(1), 1.841(1)$, and 1.850(1) $\AA$ form slightly distorted $\mathrm{TiF}_{6}$ octahedra isolated from each other by cetyltrimethylammonium cations and $\mathrm{H}_{2} \mathrm{O}$ molecules. Comparatively strong hydrogen bonds $\mathrm{O}-\mathrm{H} \cdots \mathrm{F}(2.736(2)$ and $2.716(2) \AA)$ are formed 
between $\mathrm{H}_{2} \mathrm{O}$ and the $\mathrm{TiF}_{6}$ octahedra that results in $\left[\mathrm{TiF}_{6} \cdot 2 \mathrm{H}_{2} \mathrm{O}\right]_{\mathrm{n}}{ }^{2 \mathrm{n}-}$ chains, which in their turn are linked through $\mathrm{C}-\mathrm{H} \cdots \mathrm{F}$ bonds into layers parallel to the $b c$ plane.

The crystal structure of $\left(\mathrm{enH}_{2}\right)\left[\mathrm{TiF}_{6}\right]$ determined by single-crystal X-ray diffraction method at room temperature is composed of protonated $\mathrm{enH}_{2}{ }^{2+}$ cations and octahedral complex $\left[\mathrm{TiF}_{6}\right]^{2-}$ anions [33]. The $\mathrm{enH}_{2}{ }^{2+}$ cations link $\left[\mathrm{TiF}_{6}\right]^{2-}$ anions through $\mathrm{N}-\mathrm{H} \cdots \mathrm{F}$ hydrogen bonds $(2.812$, 2.858, and $2.859 \AA$ ) into a three-dimensional network.

The crystal structure of $\left(\mathrm{C}_{6} \mathrm{H}_{21} \mathrm{~N}_{4}\right)\left[\mathrm{TiF}_{6}\right] \mathrm{F}\left(\left(\operatorname{tren} \mathrm{H}_{3}\right)\left[\mathrm{TiF}_{6}\right] \mathrm{F}\right)$ was investigated by Lhoste $e t$ al. [34]. Re-examination of $\left(\operatorname{tren} \mathrm{H}_{3}\right)\left[\mathrm{TiF}_{6}\right] \mathrm{F}$ showed that it is a hydroxyfluoridotitanate(IV), $\alpha$ $\left(\right.$ tren $\left._{3}\right)\left(\mathrm{TiF}_{4.7}(\mathrm{OH})_{1.3}\right)(\mathrm{F})$ [137] (Table 1). Fluoride complexes of titanium(IV) with ammonium cation derivatives also include two hydrazinium hexafluoridotitanates(IV), $\left(\mathrm{N}_{2} \mathrm{H}_{5}\right)_{2}\left[\mathrm{TiF}_{6}\right]$ and $\left(\mathrm{N}_{2} \mathrm{H}_{6}\right)$ [ $\left.\mathrm{TiF}_{6}\right]$. The monoclinic crystals of $\left(\mathrm{N}_{2} \mathrm{H}_{5}\right)_{2}\left[\mathrm{TiF}_{6}\right]$ [35] exhibit racemic twinning. The crystal structure of $\left(\mathrm{N}_{2} \mathrm{H}_{5}\right)_{2}\left[\mathrm{TiF}_{6}\right]$ is composed of $\left(\mathrm{N}_{2} \mathrm{H}_{5}\right)^{+}$cations and two types of slightly distorted octahedral complex $\left[\mathrm{TiF}_{6}\right]^{2-}$ anions. The $\left(\mathrm{N}_{2} \mathrm{H}_{5}\right)^{+}$cations and complex $\left[\mathrm{TiF}_{6}\right]^{2-}$ anions are linked together via $\mathrm{N}-\mathrm{H} \cdots \mathrm{F}$ and $\mathrm{N}-\mathrm{H} \cdots \mathrm{N}$ hydrogen bonds with formation of a threedimensional network.

The structure of hydrazinium hexafluoridotitanate(IV) $\left(\mathrm{N}_{2} \mathrm{H}_{6}\right)\left[\mathrm{TiF}_{6}\right.$ ] [36] was resolved with Weissenberg photographs method using the multiple-film technique. The structure is composed of slightly distorted octahedral $\left[\mathrm{TiF}_{6}\right]^{2-}$ complex anions and double-charged $\left(\mathrm{N}_{2} \mathrm{H}_{6}\right)^{2+}$ cations. The Ti-F bond length in the octahedron is 1.855(4) $\AA$, which is comparable to the $a v$. Ti-F bond lengths in the structures of fluoridotitanates(IV) containing isolated octahedral $\left[\mathrm{TiF}_{6}\right]^{2-}$ complex anions (Table 1). The $\mathrm{TiF}_{6}$ octahedra are slightly elongated along the threefold axis. The $\left(\mathrm{N}_{2} \mathrm{H}_{6}\right)^{2+}$ cations have the trans-configuration. Each $\left(\mathrm{N}_{2} \mathrm{H}_{6}\right)^{2+}$ cation is surrounded by six $\mathrm{F}$ atoms from six different $\mathrm{TiF}_{6}$ groups, thus forming with them strong $\mathrm{N}-\mathrm{H} \cdots \mathrm{F}$ hydrogen bonds $(\mathrm{N} \cdots \mathrm{F}$ $2.612 \AA$ ) linking discrete $\left(\mathrm{N}_{2} \mathrm{H}_{6}\right)^{2+}$ cations and octahedral $\left[\mathrm{TiF}_{6}\right]^{2-}$ anions into a three-dimensional network.

\subsubsection{Hybrid organic-inorganic hexafluoridotitanates(IV)}

Guanidinium hexafluoridometallates $\left[\mathrm{C}\left(\mathrm{NH}_{2}\right)_{3}\right]_{2} \mathrm{AF}_{6} \quad(\mathrm{~A}-\mathrm{Ti}, \mathrm{Si}, \mathrm{Ge}, \mathrm{Sn})$ and oxofluoridometallates $\left[\mathrm{C}\left(\mathrm{NH}_{2}\right)_{3}\right]_{2} \mathrm{NbOF}_{5}$ and $\left[\mathrm{C}\left(\mathrm{NH}_{2}\right)_{3}\right]_{2} \mathrm{WO}_{2} \mathrm{~F}_{4}$ form an isotypic series [37]. The X-ray structural study by single-crystal diffraction method was performed for 
$\left[\mathrm{C}\left(\mathrm{NH}_{2}\right)_{3}\right]_{2}\left[\mathrm{TiF}_{6}\right]$. For other compounds, unit cell dimensions were determined from the powder data. The monoclinic crystals $\left[\mathrm{C}\left(\mathrm{NH}_{2}\right)_{3}\right]_{2}\left[\mathrm{TiF}_{6}\right]$ [37] are composed of $\left[\mathrm{TiF}_{6}\right]^{2-}$ complex anions that are separated by $\mathrm{C}\left(\mathrm{NH}_{2}\right)_{3}{ }^{+}$cations. The Ti atoms in $\left[\mathrm{TiF}_{6}\right]^{2-}$ are surrounded by six fluorine atoms in a distorted octahedral environment with bond distances ranging from 1.809(1) to 1.904(1) $\AA$. The structure of $\left[\mathrm{C}\left(\mathrm{NH}_{2}\right)_{3}\right]_{2}\left[\mathrm{TiF}_{6}\right]$ is formed from layers parallel to the $x y$ axis. The $\mathrm{C}\left(\mathrm{NH}_{2}\right)_{3}{ }^{+}$cations and octahedral $\left[\mathrm{TiF}_{6}\right]^{2-}$ anions located inside each layer are linked to each other by N-H $\cdots$ F hydrogen bonds with distances in the range 2.814(5)-2.949(5) $\AA$.

The crystal structure of $\left[\mathrm{C}\left(\mathrm{NH}_{2}\right)_{3}\right]_{2}\left[\mathrm{TiF}_{6}\right]$ was re-determined by Kim et al. [28], who found the unit cell parameters for $\left[\mathrm{C}\left(\mathrm{NH}_{2}\right)_{3}\right]_{2}\left[\mathrm{TiF}_{6}\right][28]$ to be in full agreement with the previous study [37] (Table S). The Ti atoms in $\left[\mathrm{C}\left(\mathrm{NH}_{2}\right)_{3}\right]_{2}\left[\mathrm{TiF}_{6}\right]$ undergo out-of-center distortions resulting in bond asymmetries within $\mathrm{TiF}_{6}$ octahedra, which results in formation of three short (1.809(16)-

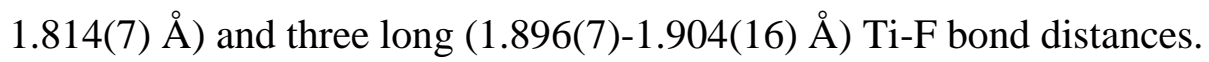

The hexafluoride complex of titanium(IV) with protonated organic base cations $\left((\mathrm{LH})_{2}\left[\mathrm{TiF}_{6}\right] \cdot \mathrm{nH}_{2} \mathrm{O}\right)$ (L-pyridine and methyl substituted pyridines) were investigated [38]. Hydrogen bonds and $\pi-\pi$ interactions between the cationic rings was responsible for the structural organization of these compounds. Pyridinium hexafluoridotitanate(IV), $\left(\mathrm{C}_{5} \mathrm{H}_{5} \mathrm{NH}\right)_{2}\left[\mathrm{TiF}_{6}\right] \cdot \mathrm{H}_{2} \mathrm{O}$ was obtained in the form of a monohydrate. The compound with the 2picolinium cation, $\left(\mathrm{C}_{6} \mathrm{H}_{7} \mathrm{NH}\right)_{2}\left[\mathrm{TiF}_{6}\right] \cdot 2 \mathrm{H}_{2} \mathrm{O}$ crystallizes with two $\mathrm{H}_{2} \mathrm{O}$ molecules, whereas hexafluoridotitanates(IV) $\left(\mathrm{C}_{7} \mathrm{H}_{9} \mathrm{NH}\right)_{2}\left[\mathrm{TiF}_{6}\right]$ and $\left(\mathrm{C}_{8} \mathrm{H}_{11} \mathrm{NH}\right)_{2}\left[\mathrm{TiF}_{6}\right]$ were obtained as anhydrous compounds. The crystal structures of $(\mathrm{LH})_{2}\left[\mathrm{TiF}_{6}\right] \cdot \mathrm{nH}_{2} \mathrm{O}\left(\mathrm{LH}=\mathrm{C}_{5} \mathrm{H}_{5} \mathrm{NH}\right.$ or $\left.\mathrm{C}_{6} \mathrm{H}_{7} \mathrm{NH}\right)$ are formed by slightly distorted $\left[\mathrm{TiF}_{6}\right]^{2-}$ complex anions, protonated organic base cations, and water molecules, which are bound by $\mathrm{N}-\mathrm{H} \cdots \mathrm{F}, \mathrm{N}-\mathrm{H} \cdots \mathrm{O}$ and $\mathrm{O}-\mathrm{H} \cdots \mathrm{F}$ hydrogen bonds. The compound $\left(\mathrm{C}_{5} \mathrm{H}_{5} \mathrm{NH}\right)_{2}\left[\mathrm{TiF}_{6}\right] \cdot \mathrm{H}_{2} \mathrm{O}$ has a chain structure. The water molecules in $\left(\mathrm{C}_{5} \mathrm{H}_{5} \mathrm{NH}\right)_{2}\left[\mathrm{TiF}_{6}\right] \cdot \mathrm{H}_{2} \mathrm{O}$ link $\left[\mathrm{TiF}_{6}\right]^{2-}$ anions by comparatively strong $\mathrm{O}-\mathrm{H} \cdots \mathrm{F}$ hydrogen bonds (2.658(2) and 2.736(2) $\AA$ ) into anionic chains.

In the structure of $\left(\mathrm{C}_{6} \mathrm{H}_{7} \mathrm{NH}\right)_{2}\left[\mathrm{TiF}_{6}\right] \cdot 2 \mathrm{H}_{2} \mathrm{O}$, water molecules form $\mathrm{O}-\mathrm{H} \cdots \mathrm{F}$ hydrogen bonds with four $\mathrm{F}$ atoms from each $\left[\mathrm{TiF}_{6}\right]^{2-}$ anion $(\mathrm{O} \cdots \mathrm{F} 2.7686(18)$ and $2.8127(18) \AA$ ) resulting in anionic chains along the $a$-axis. The cations form chains by $\pi-\pi$ stacking with the inter-ring

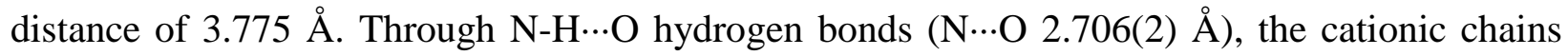


interact with the water molecules of two anionic chains forming a two-dimensional layer network extending along the $a b$ plane.

The compound $\left(\mathrm{C}_{7} \mathrm{H}_{9} \mathrm{NH}\right)_{2}\left[\mathrm{TiF}_{6}\right]$ is isostructural with $\left(\mathrm{C}_{7} \mathrm{H}_{9} \mathrm{NH}\right)_{2}\left[\mathrm{SiF}_{6}\right]$ [117], consisting of chains composed of alternating cations and anions along the $b$-axis. Within the chain, the lutidinium cations and $\left[\mathrm{TiF}_{6}\right]^{2-}$ anions are linked by bifurcated $\mathrm{N}-\mathrm{H} \cdots \mathrm{F}$ hydrogen bonds with the $\mathrm{N} \cdots \mathrm{F}$ distance of $2.7676(18) \AA$. In contrast, the crystal structure of $\left(\mathrm{C}_{8} \mathrm{H}_{11} \mathrm{NH}\right)_{2}\left[\mathrm{TiF}_{6}\right]$ is formed by discrete $\left(\mathrm{C}_{8} \mathrm{H}_{11} \mathrm{NH}\right)^{+}$cations and octahedral $\left[\mathrm{TiF}_{6}\right]^{2-}$ complex anions. Two fluorine atoms from each $\left[\mathrm{TiF}_{6}\right]^{2-}$ anion are involved into formation of rather strong $\mathrm{N}-\mathrm{H} \cdots \mathrm{F}$ hydrogen bonds (N...F 2.666(2) A) with nitrogen atoms of two 2,4,6-collidinium cations. The crystal structure of $\left(\mathrm{C}_{8} \mathrm{H}_{11} \mathrm{NH}\right)_{2}\left[\mathrm{TiF}_{6}\right]$ can be represented as $\cdots\left[\mathrm{TiF}_{6}\right]^{2-} \cdots \mathrm{LH}^{+} \cdots \mathrm{LH}^{+} \ldots\left[\mathrm{TiF}_{6}\right]^{2-} \cdots \mathrm{LH}^{+} \cdots \mathrm{LH}^{+} \ldots$ chains lying in the [101] direction of the $a c$ plane.

Isolated octahedral $\left[\mathrm{TiF}_{6}\right]^{2-}$ complex anions, diprotonated 1,4-diazobicyclo[2.2.2]octane cations compensating the anions' charge and lattice $\mathrm{H}_{2} \mathrm{O}$ molecules build up the crystal structure of $\left(\right.$ dabcoH$\left._{2}\right)\left[\mathrm{TiF}_{6}\right] \cdot \mathrm{H}_{2} \mathrm{O}$ (dabco = 1,4-diazobicyclo[2.2.2]octane) [39]. The Ti atoms located along the 2 axis form two types of octahedral $\left[\mathrm{Ti}(1) \mathrm{F}_{6}\right]^{2-}$ and $\left[\mathrm{Ti}(2) \mathrm{F}_{6}\right]^{2-}$ anions with similar values of Ti-F bond lengths (Table 1). The water molecules and nitrogen atoms of the cations participate in hydrogen bonding with fluorine and oxygen atoms forming a three-dimensional $\mathrm{H}$ bridging network.

Monoprotonated phenanthrolinium cations, phen $\mathrm{H}^{+}$and isolated octahedral $\left[\mathrm{TiF}_{6}\right]^{2-}$ complex anions form $(\mathrm{phenH})_{2}\left[\mathrm{TiF}_{6}\right][40]$. The $\left[\mathrm{TiF}_{6}\right]^{2-}$ anions are located in the crystallographic inversion centers. The $\left[\mathrm{TiF}_{6}\right]^{2-}$ anions located between two phenH $\mathrm{H}^{+}$cations are involved into two strong $\mathrm{N}-\mathrm{H} \cdots \mathrm{F}$ hydrogen bonds $(\mathrm{N}(1) \cdots \mathrm{F}(1) 2.6630(13) \AA)$. The Ti-F(1) distance with the fluorine atom participating in the hydrogen bond formation is longer by $0.03 \AA$ as compared to other Ti-F bond lengths in the anion (Table 1). Adjacent centrosymmetrical cations are linked by $\pi-\pi$ interactions with distances ranging from 3.435 to $3.539 \AA$.

The compound $(\mathrm{ImH})_{2}\left[\mathrm{TiF}_{6}\right] \cdot 2 \mathrm{HF}\left(\mathrm{Im}\right.$, imidazole, $\mathrm{C}_{3} \mathrm{H}_{4} \mathrm{~N}_{2}$ ) was synthesized in anhydrous hydrogen fluoride. The structure of monoclinic $(\mathrm{ImH})_{2}\left[\mathrm{TiF}_{6}\right] \cdot 2 \mathrm{HF}$ is composed of imidazolium $\left(\mathrm{ImH}^{+}\right)$cations, octahedral $\left[\mathrm{TiF}_{6}\right]^{2-}$ anions, and HF solvent molecules [41]. The HF molecules are bonded to the $\mathrm{F}\left[\mathrm{TiF}_{6}\right]^{2-}$ anions via hydrogen bonds $(2.374(6) \AA)$, which causes the increase of the Ti-F(2) bond length (1.908(4) $\AA$ ) as compared to other Ti-F distances (av. 1.824(4) $\AA$ ). Each 
$\left[\mathrm{TiF}_{6}\right]^{2-}$ anion is bonded to six $\mathrm{ImH}^{+}$cations, and the cations are each bonded to three $\mathrm{TiF}_{6}$ units via weak (> $3.0 \AA$ A) $\mathrm{N}-\mathrm{H} \cdots \mathrm{F}$ and $\mathrm{C}-\mathrm{H} \cdots \mathrm{F}$ hydrogen bonds.

The synthesis of a series of $\left(\mathrm{Ph}_{4} \mathrm{P}\right)_{2} \mathrm{MCl}_{6}(\mathrm{M}=\mathrm{Ti}, \mathrm{Zr}, \mathrm{Hf}, \mathrm{Th}, \mathrm{U}, \mathrm{Np}, \mathrm{Pu})$ compounds, including hexafluoridotitanate(IV) $\left(\mathrm{Ph}_{4} \mathrm{P}\right)_{2} \mathrm{TiF}_{6}$, was reported by Minasian et al. [42]. The compound $\left(\mathrm{Ph}_{4} \mathrm{P}\right)_{2} \mathrm{TiF}_{6} \cdot \mathrm{MeCN}$ was obtained by recrystallization of $\left(\mathrm{Ph}_{4} \mathrm{P}\right)_{2} \mathrm{TiF}_{6}$ from the $\mathrm{MeCN}$ solution: the former single crystals were suitable for X-ray diffraction studies. Triclinic $\left(\mathrm{Ph}_{4} \mathrm{P}\right)_{2}\left[\mathrm{TiF}_{6}\right] \cdot \mathrm{MeCN}$ crystals consist of disordered $\mathrm{Ph}_{4} \mathrm{P}^{+}$cations, $\left[\mathrm{TiF}_{6}\right]^{2-}$ complex anions, and solvate MeCN molecules. The $\left[\mathrm{TiF}_{6}\right]^{2-}$ complex anions have almost regular octahedral structure. The unique Ti-F bond lengths have values characteristic for those in the structures of other fluoridotitanates(IV) with isolated octahedral $\left[\mathrm{TiF}_{6}\right]^{2-}$ complex anions (Table 1).

\subsubsection{Divalent metal hexafluoridotitanates(IV)}

Fluoride complexes of titanium(IV) $\left[\mathrm{M}^{\mathrm{II}}\left(\mathrm{H}_{2} \mathrm{O}\right)_{6}\right]\left[\mathrm{TiF}_{6}\right]$ represent a large group of compounds of the general formula $\left[\mathrm{M}^{\mathrm{II}}\left(\mathrm{H}_{2} \mathrm{O}\right)_{6}\right]\left[\mathrm{AF}_{6}\right]$, where $\mathrm{M}$ is a transition metal $(\mathrm{M}=\mathrm{Mn}, \mathrm{Fe}$, $\mathrm{Co}, \mathrm{Ni}, \mathrm{Zn}, \mathrm{Cd})$ and $\mathrm{A}$ is a Group IV element (A = Si, Ge, Sn, Pb, Ti, Zr, Hf), making an isomorphic series. The crystal structures of a number of isostructural compounds of general formula $\left[\mathrm{M}^{\mathrm{II}}\left(\mathrm{H}_{2} \mathrm{O}\right)_{6}\right]\left[\mathrm{AF}_{6}\right]$ have been reported, including $\left[\mathrm{Fe}\left(\mathrm{H}_{2} \mathrm{O}\right)_{6}\right]\left[\mathrm{SiF}_{6}\right]$ [118], $\left[\mathrm{M}\left(\mathrm{H}_{2} \mathrm{O}\right)_{6}\right]\left[\mathrm{SiF}_{6}\right](\mathrm{M}=\mathrm{Co}, \mathrm{Ni}, \mathrm{Zn})[119],\left[\mathrm{M}\left(\mathrm{H}_{2} \mathrm{O}\right)_{6}\right]\left[\mathrm{GeF}_{6}\right](\mathrm{M}=\mathrm{Fe}, \mathrm{Co}, \mathrm{Ni})[120]$, and $\left[\mathrm{M}\left(\mathrm{H}_{2} \mathrm{O}\right)_{6}\right]\left[\mathrm{SnF}_{6}\right](\mathrm{M}=\mathrm{Co}, \mathrm{Ni})[121]$. The compounds crystallize in the trigonal symmetry $(R \overline{3})$ and belonged to the $\left[\mathrm{Ni}\left(\mathrm{H}_{2} \mathrm{O}\right)_{6}\right]\left[\mathrm{SnCl}_{6}\right]$ structural type [122]. Unlike $\left[\mathrm{M}^{\mathrm{II}}\left(\mathrm{H}_{2} \mathrm{O}\right)_{6}\right]\left[\mathrm{AF}_{6}\right]$, the fluoride complexes $\left[\mathrm{Cu}\left(\mathrm{H}_{2} \mathrm{O}\right)_{4}\right]\left[\mathrm{AF}_{6}\right](\mathrm{A}=\mathrm{Si}, \mathrm{Sn}, \mathrm{Ti}, \mathrm{Zr}, \mathrm{Hf})$, according to the X-ray powder diffraction study, crystallize in the monoclinic symmetry and are isostructural [123].

Depending on the ligand in the complex $\left[\mathrm{M}(\mathrm{L})_{\mathrm{n}}\right]^{2+}$ cation, fluoridotitanates(IV) of divalent transition metals can be conditionally divided into two groups. The first one includes fluoride complexes of $\mathrm{Ti}(\mathrm{IV})$ containing hydrated cations, the second one - fluoridotitanates(IV), in which $\mathrm{M}^{2+}$ cations are coordinated by neutral organic ligands (Table 1).

The series $\left[\mathrm{M}^{\mathrm{II}}\left(\mathrm{H}_{2} \mathrm{O}\right)_{6}\right]\left[\mathrm{TiF}_{6}\right](\mathrm{M}=\mathrm{Mn}, \mathrm{Fe}, \mathrm{Co}, \mathrm{Ni}, \mathrm{Zn}, \mathrm{Cd})$, the $\left[\mathrm{Mn}\left(\mathrm{H}_{2} \mathrm{O}\right)_{6}\right]\left[\mathrm{TiF}_{6}\right]$, $\left[\mathrm{Zn}\left(\mathrm{H}_{2} \mathrm{O}\right)_{6}\right]\left[\mathrm{TiF}_{6}\right]$, and $\left[\mathrm{Ni}\left(\mathrm{H}_{2} \mathrm{O}\right)_{6}\right]\left[\mathrm{TiF}_{6}\right]$ was studied. The crystal structures of $\left[\mathrm{Mn}\left(\mathrm{H}_{2} \mathrm{O}\right)_{6}\right]\left[\mathrm{TiF}_{6}\right]$ and $\left[\mathrm{Zn}\left(\mathrm{H}_{2} \mathrm{O}\right)_{6}\right]\left[\mathrm{TiF}_{6}\right]$ were determined by X-ray diffraction on single crystals [43] and were 
isotypic with that of $\mathrm{FeSiF}_{6} \cdot 6 \mathrm{H}_{2} \mathrm{O}[118](R \overline{3} m)$ which are not disordered. The crystal structures of $\left[\mathrm{Mn}\left(\mathrm{H}_{2} \mathrm{O}\right)_{6}\right]\left[\mathrm{TiF}_{6}\right]$ and $\left[\mathrm{Zn}\left(\mathrm{H}_{2} \mathrm{O}\right)_{6}\right]\left[\mathrm{TiF}_{6}\right]$ consist of complex $\left[\mathrm{Mn}\left(\mathrm{H}_{2} \mathrm{O}\right)_{6}\right]^{2+}$ and $\left[\mathrm{Zn}\left(\mathrm{H}_{2} \mathrm{O}\right)_{6}\right]^{2+}$ cations, respectively, and complex $\left[\mathrm{TiF}_{6}\right]^{2-}$ anions having almost octahedral configuration and are packed in a rhombohedrally distorted CsCl-type structure. The Ti-F bond lengths in $\left[\mathrm{TiF}_{6}\right]^{2-}$ anions of both compounds are virtually equal: 1.823(1) and 1.829(1) A. There is some difference in $\mathrm{M}-\mathrm{OH}_{2}$ bond lengths in $\left[\mathrm{Mn}\left(\mathrm{H}_{2} \mathrm{O}\right)_{6}\right]^{2+}$ and $\left[\mathrm{Zn}\left(\mathrm{H}_{2} \mathrm{O}\right)_{6}\right]^{2+}$ cations (2.163(2) vs 2.082(2) $\AA$, respectively).

The $\mathrm{H}_{2} \mathrm{O}$ molecules form with $\mathrm{F}$ atoms of $\left[\mathrm{TiF}_{6}\right]^{2-}$ complex anions moderately strong O-

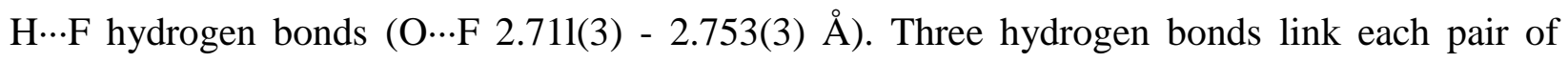
adjacent $\mathrm{M}\left(\mathrm{H}_{2} \mathrm{O}\right)_{6}$ and $\mathrm{TiF}_{6}$ octahedra into columns parallel to the threefold axis, while one hydrogen bond links an octahedron to each of its six neighboring octahedra in other columns. Hydrogen bonds and ionic interaction form a three-dimensional network.

The crystal structure of $\left[\mathrm{Zn}\left(\mathrm{H}_{2} \mathrm{O}\right)_{6}\right]\left[\mathrm{TiF}_{6}\right]$ was re-determined [44]. The cell dimensions and the space group of the structure agree with the data of [43] (Table S). The re-determined structure of $\left[\mathrm{Zn}\left(\mathrm{H}_{2} \mathrm{O}\right)_{6}\right]\left[\mathrm{TiF}_{6}\right]$ is disordered and isostructural with $\left[\mathrm{Zn}\left(\mathrm{H}_{2} \mathrm{O}\right)_{6}\right]\left[\mathrm{SiF}_{6}\right]$ [119]. The low temperature phase transition was studied, and the symmetry of $\left[\mathrm{Zn}\left(\mathrm{H}_{2} \mathrm{O}\right)_{6}\right]\left[\mathrm{TiF}_{6}\right]$ changed from rhombohedral to monoclinic. The monoclinic phase is isostructural with the low temperature phase of $\left[\mathrm{Mg}\left(\mathrm{H}_{2} \mathrm{O}\right)_{6}\right]\left[\mathrm{SiF}_{6}\right][124]$.

The rhombohedral crystal structure of $\left[\mathrm{Ni}\left(\mathrm{H}_{2} \mathrm{O}\right)_{6}\right]\left[\mathrm{TiF}_{6}\right][45]$ is isostructural with the $\left[\mathrm{M}^{\mathrm{II}}\left(\mathrm{H}_{2} \mathrm{O}\right)_{6}\right]\left[\mathrm{AF}_{6}\right]$ series. The $\left[\mathrm{Ni}\left(\mathrm{H}_{2} \mathrm{O}\right)_{6}\right]\left[\mathrm{TiF}_{6}\right]$ structure, just like those of $\left[\mathrm{M}^{\mathrm{II}}\left(\mathrm{H}_{2} \mathrm{O}\right)_{6}\right]\left[\mathrm{AF}_{6}\right]$, is formed by virtually regular octahedral $\left[\mathrm{Ni}\left(\mathrm{H}_{2} \mathrm{O}\right)_{6}\right]^{2+}$ complex cations and $\left[\mathrm{TiF}_{6}\right]^{2-}$ complex anions packed into a distorted pseudo- $\mathrm{CsCl}$ type unit. The $\mathrm{Ni}\left(\mathrm{H}_{2} \mathrm{O}\right)_{6}$ are regular octahedra with equivalent $\mathrm{Ni}-\mathrm{O}$ bond lengths are 2.038(5), whereas the $\mathrm{O}-\mathrm{Ni}-\mathrm{O}$ angles are in the range 88.7(2)-

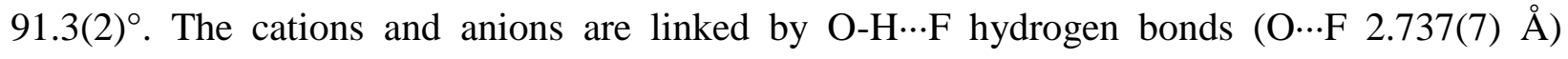
forming an H-bonding network.

The compound $\left[\mathrm{Ni}\left(\mathrm{H}_{2} \mathrm{O}\right)_{6}\right]\left[\mathrm{TiF}_{6}\right] \cdot(\mathrm{hmta})_{2} \cdot \mathrm{H}_{2} \mathrm{O}$ was obtained in the form of a crystal solvate. The $\left[\mathrm{Ni}\left(\mathrm{H}_{2} \mathrm{O}\right)_{6}\right]\left[\mathrm{TiF}_{6}\right] \cdot(\mathrm{hmta})_{2} \cdot \mathrm{H}_{2} \mathrm{O}$ structure [46] differs significantly from that of $\left[\mathrm{Ni}\left(\mathrm{H}_{2} \mathrm{O}\right)_{6}\right]\left[\mathrm{TiF}_{6}\right][45]$. Aside from $\left[\mathrm{Ni}\left(\mathrm{H}_{2} \mathrm{O}\right)_{6}\right]^{2+}$ cations and $\left[\mathrm{TiF}_{6}\right]^{2-}$ anions, the triclinic crystal structure of $\left[\mathrm{Ni}\left(\mathrm{H}_{2} \mathrm{O}\right)_{6}\right]\left[\mathrm{TiF}_{6}\right] \cdot(\mathrm{hmta})_{2} \cdot \mathrm{H}_{2} \mathrm{O}$ also contains solvate hmta and $\mathrm{H}_{2} \mathrm{O}$ molecules. The $\left[\mathrm{Ni}\left(\mathrm{H}_{2} \mathrm{O}\right)_{6}\right]^{2+}$ complex cations and $\left[\mathrm{TiF}_{6}\right]^{2-}$ anions are substantially distorted. The Ni-O distances 
are in the range of 2.0269(9) to 2.0743(9) $\AA$. Hydrogen bonds assemble the cations, anions, and lattice solvent molecules into a three-dimensional network.

A brief report about the $\mathrm{CuTiF}_{6} \cdot 4 \mathrm{H}_{2} \mathrm{O}$ structure has appeared [123]. Monoclinic $\left[\mathrm{Cu}\left(\mathrm{H}_{2} \mathrm{O}\right)_{4}\right]\left[\mathrm{TiF}_{6}\right]$ crystals [47] are composed of distorted $\left[\mathrm{Cu}\left(\mathrm{H}_{2} \mathrm{O}\right)_{4}\right]^{2+}$ complex cations and almost regular octahedral $\left[\mathrm{TiF}_{6}\right]^{2-}$ complex anions. Each $\mathrm{Cu}$ atom is surrounded by four coordinated $\mathrm{H}_{2} \mathrm{O}$ molecules and two $\mathrm{F}$ atoms belonging to adjacent $\left[\mathrm{TiF}_{6}\right]^{2-}$ anions with formation of the $\mathrm{Cu}\left(\mathrm{H}_{2} \mathrm{O}\right)_{4} \mathrm{~F}_{2}$ octahedron. The $\mathrm{Cu}-\mathrm{O}$ distances range from 1.95(2) to 1.97(2) $\AA$, while the length of the $\mathrm{Cu}-\mathrm{F}$ bond with axial fluorine atoms is 2.31(3) $\AA$. Similar $\mathrm{Cu}-\mathrm{F}$ bond lengths $\left(\mathrm{Cu}-\mathrm{F}_{\text {equatorial }} 1.93(3) \AA\right.$ and $\left.\mathrm{Cu}-\mathrm{F}_{\text {axial }} 2.27(3) \AA\right)$ were found in the distorted octahedral $\mathrm{CuF}_{6}$ group of the crystal structure of $\mathrm{CuF}_{2}$ [125]. The $\left[\mathrm{Cu}\left(\mathrm{H}_{2} \mathrm{O}\right)_{4}\right]^{2+}$ complex cations and $\left[\mathrm{TiF}_{6}\right]^{2-}$ anions linked through $\mathrm{O}-\mathrm{H} \cdots \mathrm{F}$ hydrogen bonds form infinite linear $\cdots\left[\mathrm{TiF}_{6}\right]^{2-}$ $\ldots\left[\mathrm{Cu}\left(\mathrm{H}_{2} \mathrm{O}\right)_{4}\right]^{2+} \ldots\left[\mathrm{TiF}_{6}\right]^{2-} \ldots\left[\mathrm{Cu}\left(\mathrm{H}_{2} \mathrm{O}\right)_{4}\right]^{2+} \ldots\left[\mathrm{TiF}_{6}\right]^{2-} \ldots$ chains directed along the [101] axis. Inter-

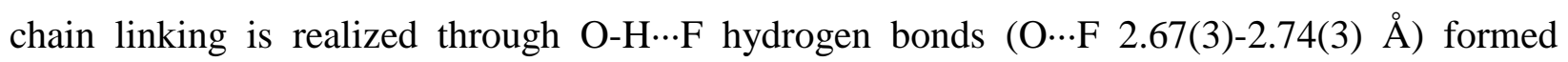
between fluorine atoms of one chain and $\mathrm{H}_{2} \mathrm{O}$ of an adjacent chain.

Studies of the crystal structure of $\mathrm{SrTiF}_{6} \cdot 2 \mathrm{H}_{2} \mathrm{O}$ [48] at $297 \mathrm{~K}$ with isotropic displacement parameters for the non-hydrogen atoms (R-value 0.060) did not allow determination of $\mathrm{H}$ atoms coordinates. To refine the $\mathrm{SrTiF}_{6} \cdot 2 \mathrm{H}_{2} \mathrm{O}$ structure and $\mathrm{H}$ atoms positions, this structure was redetermined at $173 \mathrm{~K}$ [49]. The crystal structure of $\mathrm{SrTiF}_{6} \cdot 2 \mathrm{H}_{2} \mathrm{O}$ is built up by almost regular $\mathrm{TiF}_{6}$ octahedra and distorted $\mathrm{SrF}_{5} \mathrm{O}_{3}$ groups. In $\mathrm{TiF}_{6}$ polyhedra, the Ti-F distances range from 1.84(1) to $1.88(1) \AA\left(a v .1 .86 \AA\right.$ ), while the F-Ti-F cis-angles are in the range $86.9-92.8^{\circ}\left(a v .89 .7^{\circ}\right)$. The $\mathrm{Sr}$ atoms, which are coordinated by five $\mathrm{F}$ atoms and three oxygen atoms from $\mathrm{H}_{2} \mathrm{O}$ molecules, are located in distorted square antiprisms. $\mathrm{SrF}_{5} \mathrm{O}_{3}$ polyhedra are linked pairwise into dimers through a common $\mathrm{O} \cdots \mathrm{O}(3.14 \AA)$ edge, whose midpoint coincides with the symmetry center. The $\mathrm{Sr}-\mathrm{F}$ and $\mathrm{Sr}-\mathrm{O}$ bond lengths in the $\mathrm{SrF}_{5} \mathrm{O}_{3}$ polyhedron are in the ranges 2.45_-_2.51 and $2.61-2.70 \AA$, respectively.

The $\mathrm{SrTiF}_{6} \cdot 2 \mathrm{H}_{2} \mathrm{O}$ structure is composed of $\mathrm{TiF}_{6}$ octahedra and layers of $\mathrm{SrF}_{5} \mathrm{O}_{3}$. Five out of six $\mathrm{F}$ atoms on each $\mathrm{TiF}_{6}$ octahedron are involved in bonding to five different $\mathrm{SrF}_{5} \mathrm{O}_{3}$ polyhedra located in layers above and below the layer of $\mathrm{TiF}_{6}$ octahedra. The $\mathrm{F}$ atom not included into the $\mathrm{Sr}$ atom polyhedron is involved into the $\mathrm{O}-\mathrm{H} \cdots \mathrm{F}$ hydrogen bond with $\mathrm{O} \cdots \mathrm{F}$ distances equal to 
2.76 and $2.77 \AA$. Dimers of $\mathrm{SrF}_{5} \mathrm{O}_{3}$ polyhedra linked to $\mathrm{TiF}_{6}$ octahedra form a three-dimensional network. Hydrogen bonds provide extra rigidity of the structure framework.

The crystal structure of $\left[\mathrm{Sn}_{6} \mathrm{~F}_{10}\right]\left[\mathrm{TiF}_{6}\right]$ [50] differs from the above described structures. It simultaneously contains fluoride-tin complex cations and fluoride-titanium complex anions. It is built up by $\left[\mathrm{Sn}_{6} \mathrm{~F}_{10}\right]_{\mathrm{n}}{ }^{2+}$ polymeric cationic layers normal to the $a$-axis and octahedral $\left[\mathrm{TiF}_{6}\right]^{2-}$ complex anions occupying special positions along the two-fold axes. The complex $\left[\mathrm{Sn}_{6} \mathrm{~F}_{10}\right]^{2+}$ cation contains three crystallographically independent tin atoms: $\mathrm{Sn}(1), \operatorname{Sn}(2)$, and $\mathrm{Sn}(3)$. The coordination polyhedra of the $\mathrm{Sn}(1)$ and $\mathrm{Sn}(3)$ atoms comprise distorted trigonal bipyramids with the apical positions occupied by $\mathrm{F}$ atoms and equatorial positions occupied by two $\mathrm{F}$ atoms and the lone pair. The $\mathrm{Sn}(2)$ polyhedron is a trigonal pyramid with the LP in the apex and the $\mathrm{F}$ atoms in the base. In the $\mathrm{Sn}(1), \mathrm{Sn}(2)$ and $\mathrm{Sn}(3)$ polyhedra, the $\mathrm{Sn}-\mathrm{F}$ bond lengths are in the ranges 2.155(1)-2.408(2), 2.068(1)-2.182(2), and 2.044(2)-2.147(1) Å, respectively. Through electrostatic and van der Waals interactions, $\left[\mathrm{Sn}_{6} \mathrm{~F}_{10}\right]_{n}{ }^{2+}$ polymeric layers and $\left[\mathrm{TiF}_{6}\right]^{2-}$ complex anions are linked into a three-dimensional network.

The crystal structure of $\mathrm{Tl}_{5} \mathrm{TiF}_{9}$ [51] also contains layered polymeric complex cations. The building units of the $\mathrm{Tl}_{5} \mathrm{TiF}_{9}$ structure are $\left[\mathrm{Tl}_{5} \mathrm{~F}_{3}\right]^{2+}$ cationic layers directed along the crystal $c$ axis and isolated $\left[\mathrm{TiF}_{6}\right]^{2-}$ complex anions. The $\left[\mathrm{Tl}_{5} \mathrm{~F}_{3}\right]^{2+}$ polymeric layers contain two types of crystallographically independent $\mathrm{Tl}$ atoms. The $\mathrm{Tl}(1)$ atoms are surrounded by $8 \mathrm{~F}$ atoms removed from the Ti atom at distances from 2.63(1) to 3.34(1) $\AA$ with a bisphenoidal shaped coordination polyhedron. The $\mathrm{Tl}(2)$ atoms are coordinated by $8 \mathrm{~F}$ atoms separated from the central atom by a distance between 2.79(1) and 3.40(1) A. The coordination polyhedron of the $\mathrm{Tl}(2)$ atom has a relatively open indefinite shape indicating the presence of a stereochemically active electron lone pair. The $\left[\mathrm{Tl}_{5} \mathrm{~F}_{3}\right]^{2+}$ layers include three types of atomic positions. Central positions in the layer are formed by the $\mathrm{Tl}(2)$ atom with three $\mathrm{F}$ atoms, whereas peripheral atomic positions are occupied by two $\mathrm{Tl}(1)$ atoms. The unique $\mathrm{Ti}-\mathrm{F}$ bond lengths in $\mathrm{TiF}_{6}$ octahedra are $1.86(1)$ and $1.87(1) \AA$. The $\left[\mathrm{TiF}_{6}\right]^{2-}$ octahedra link $\left[\mathrm{Tl}_{5} \mathrm{~F}_{3}\right]^{2+}$ layers into a threedimensional structure.

\subsubsection{Double fluoride complexes of titanium(IV)}


The crystal structures of three double fluoride complexes of titanium(IV) $\left(\mathrm{Na}_{2}\left[\mathrm{TiF}_{6}\right] \cdot \mathrm{NaHF}_{2}\right.$, $\left[\mathrm{Cu}\left(\mathrm{H}_{2} \mathrm{O}\right)_{4}\right]\left[\mathrm{TiF}_{6}\right] \cdot \mathrm{NH}_{4} \mathrm{~F}$, and $\left.\left(\mathrm{N}_{2} \mathrm{H}_{6}\right)\left[\mathrm{TiF}_{6}\right] \cdot\left(\mathrm{N}_{2} \mathrm{H}_{6}\right) \mathrm{F}_{2}\right)$ containing $\left[\mathrm{TiF}_{6}\right]^{2-}$ anions and noncoordinated fluoride anions were investigated (Table 1). The crystal structure of $\mathrm{Na}_{2}\left[\mathrm{TiF}_{6}\right] \cdot \mathrm{NaHF}_{2}$ [52] is composed of $\mathrm{Na}^{+}$cations, slightly distorted octahedral complex anions $\left[\mathrm{TiF}_{6}\right]^{2-}$, and $\mathrm{HF}_{2}^{-}$anions. In the $\mathrm{HF}_{2}^{-}$anion the distance between $\mathrm{F}$ atoms is equal to $2.36 \AA$. Based on the neutron diffraction data obtained from single crystals of $\mathrm{NaHF}_{2}$, the F-H-F distance in $\mathrm{NaHF}_{2}$ is somewhat shorter at 2.264(3) $\AA$ [126]. The crystal structure of $\mathrm{Na}_{2}\left[\mathrm{TiF}_{6}\right] \cdot \mathrm{NaHF}_{2}$ is similar to that of $\mathrm{Na}_{2}\left[\mathrm{SnF}_{6}\right] \cdot \mathrm{NaHF}_{2}$ [127] and $\mathrm{K}_{2}\left[\mathrm{NbOF}_{5}\right] \cdot \mathrm{KHF}_{2}$ [128] with the only distinction being the orientation of $\mathrm{HF}_{2}^{-}$anions in the structure.

The $\mathrm{NH}_{4} \mathrm{CuAF}_{7} \cdot 4 \mathrm{H}_{2} \mathrm{O}(\mathrm{A}=\mathrm{Si}, \mathrm{Ti}, \mathrm{Sn})$ compounds crystallize in the tetragonal symmetry and form an isotypic series [129]. The structural study was performed for $\mathrm{NH}_{4} \mathrm{CuTiF}_{7} \cdot 4 \mathrm{H}_{2} \mathrm{O}$. As was established in the preliminary study, $\mathrm{NH}_{4} \mathrm{CuTiF}_{7} \cdot 4 \mathrm{H}_{2} \mathrm{O}$ comprises a double salt $\left[\mathrm{Cu}\left(\mathrm{H}_{2} \mathrm{O}\right)_{4}\right]\left[\mathrm{TiF}_{6}\right] \cdot \mathrm{NH}_{4} \mathrm{~F}$ [129]. The crystal structure is composed of $\left[\mathrm{Cu}\left(\mathrm{H}_{2} \mathrm{O}\right)_{4}\right]^{2+}$ complex cations, $\left[\mathrm{TiF}_{6}\right]^{2-}$ complex anions, isolated $\mathrm{NH}_{4}{ }^{+}$cations, and $\mathrm{F}^{-}$anions [53]. The structure is similar to that of $\left[\mathrm{Cu}\left(\mathrm{H}_{2} \mathrm{O}\right)_{4}\right]\left[\mathrm{TiF}_{6}\right][47]$. The $\left[\mathrm{Cu}\left(\mathrm{H}_{2} \mathrm{O}\right)_{4}\right]^{2+}$ complex cations are square-planar. The $\left[\mathrm{Cu}\left(\mathrm{H}_{2} \mathrm{O}\right)_{4}\right]^{2+}$ cations form octahedral $\mathrm{Cu}\left(\mathrm{H}_{2} \mathrm{O}\right)_{4} \mathrm{~F}_{2}$ units by bonding to two $\mathrm{F}$ atoms of adjacent $\left[\mathrm{TiF}_{6}\right]^{2-}$ anions.

The $\left[\mathrm{TiF}_{6}\right]^{2-}$ complex anions are distorted octahedra as a result of the fluoride bonds to the $\left[\mathrm{Cu}\left(\mathrm{H}_{2} \mathrm{O}\right)_{4}\right]^{2+}$ cations. In $\left[\mathrm{Cu}\left(\mathrm{H}_{2} \mathrm{O}\right)_{4}\right]\left[\mathrm{TiF}_{6}\right] \cdot \mathrm{NH}_{4} \mathrm{~F}$, as in $\left[\mathrm{Cu}\left(\mathrm{H}_{2} \mathrm{O}\right)_{4}\right]\left[\mathrm{TiF}_{6}\right]$, the $\left[\mathrm{Cu}\left(\mathrm{H}_{2} \mathrm{O}\right)_{4}\right]^{2+}$ cations and $\left[\mathrm{TiF}_{6}\right]^{2-}$ anions form infinite linear $\ldots\left[\mathrm{TiF}_{6}\right]^{2-} \ldots\left[\mathrm{Cu}\left(\mathrm{H}_{2} \mathrm{O}\right)_{4}\right]^{2+} \ldots\left[\mathrm{TiF}_{6}\right]^{2-}$ $\ldots\left[\mathrm{Cu}\left(\mathrm{H}_{2} \mathrm{O}\right)_{4}\right]^{2+} \ldots\left[\mathrm{TiF}_{6}\right]^{2-} \ldots$ chains, between which isolated $\mathrm{NH}_{4}{ }^{+}$cations and $\mathrm{F}^{-}$anions are located. Each $\mathrm{F}^{-}$anion is tetrahedrally surrounded by four $\mathrm{H}_{2} \mathrm{O}$ molecules, whereas each $\mathrm{NH}_{4}{ }^{+}$ cation is tetrahedrally surrounded by four fluorine atoms from $\left[\mathrm{TiF}_{6}\right]^{2-}$ anions. This generates a branched system of $\mathrm{O}-\mathrm{H} \cdots \mathrm{F}$ and $\mathrm{N}-\mathrm{H} \cdots \mathrm{F}$ hydrogen bonds. The strongest $\mathrm{O}-\mathrm{H} \cdots \mathrm{F}$ hydrogen bond is formed by coordinated $\mathrm{H}_{2} \mathrm{O}$ molecules of $\left[\mathrm{Cu}\left(\mathrm{H}_{2} \mathrm{O}\right)_{4}\right]^{2+}$ cations with isolated $\mathrm{F}^{-}$ions $(2.520(26)$ $\AA$ ). Other hydrogen bonds in the structure are weaker (2.713-2.775 $\AA$ ). The structural units are linked into a three-dimensional network through hydrogen bonds.

Hydrazinium fluoridotitanates(IV) $\left(\mathrm{N}_{2} \mathrm{H}_{5}\right)_{2}\left[\mathrm{TiF}_{6}\right],\left(\mathrm{N}_{2} \mathrm{H}_{6}\right)\left[\mathrm{TiF}_{6}\right]$, and $\left(\mathrm{N}_{2} \mathrm{H}_{6}\right)_{2} \mathrm{TiF}_{8}$ have been described by Slivnik et al. [130]. (The crystal structures of $\left(\mathrm{N}_{2} \mathrm{H}_{5}\right)_{2}\left[\mathrm{TiF}_{6}\right]$ [35] and $\left(\mathrm{N}_{2} \mathrm{H}_{6}\right)\left[\mathrm{TiF}_{6}\right]$ [36] were considered in section 2.1.4). Based on the results of thermal and IR spectroscopy 
study, the compound $\left(\mathrm{N}_{2} \mathrm{H}_{6}\right)_{2} \mathrm{TiF}_{8}$ was described with the formula $\left(\mathrm{N}_{2} \mathrm{H}_{5}\right)_{2}\left[\mathrm{TiF}_{6}\right] \cdot 2 \mathrm{HF}$. The X-ray structural study of $\left(\mathrm{N}_{2} \mathrm{H}_{5}\right)_{2} \mathrm{TiF}_{6} \cdot 2 \mathrm{HF}$ demonstrated that this compound is a double salt $\left(\mathrm{N}_{2} \mathrm{H}_{6}\right)\left[\mathrm{TiF}_{6}\right] \cdot\left(\mathrm{N}_{2} \mathrm{H}_{6}\right) \mathrm{F}_{2}$. The structure is formed by $\mathrm{N}_{2} \mathrm{H}_{6}{ }^{2+}$ cations, [TiF $]^{2-}$ complex anions, and isolated $\mathrm{F}^{-}$anions [54]. The $\left[\mathrm{TiF}_{6}\right]^{2-}$ complex anions have a virtually regular octahedral structure. In the $\mathrm{N}_{2} \mathrm{H}_{6}{ }^{2+}$ cation, the $\mathrm{N}-\mathrm{N}$ distance is equal to $1.441(5) \AA$, which is somewhat smaller than the N-N bond length $1.474(7) \AA$ in the $\left(\mathrm{N}_{2} \mathrm{H}_{6}\right)\left[\mathrm{TiF}_{6}\right.$ ] structure [36]. Each $\mathrm{N}_{2} \mathrm{H}_{6}{ }^{2+}$ cation forms six $\mathrm{N}-\mathrm{H} \cdots \mathrm{F}$ hydrogen bonds. As compared to hydrogen bonds formed with participation of anions $\mathrm{F}$

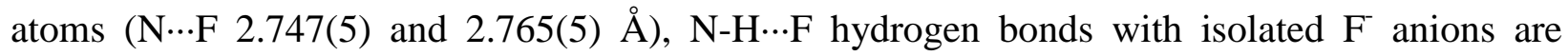
substantially stronger and lie in the range 2.568(5)-2.700(5) $\AA$. A system of N-H $\cdots$ F hydrogen bonds links $\mathrm{N}_{2} \mathrm{H}_{6}{ }^{2+}$ cations and $\left[\mathrm{TiF}_{6}\right]^{2-}$ and $\mathrm{F}^{-}$anions into a three-dimensional network.

\subsubsection{Hexafluoridotitanates(IV) with hybrid divalent and trivalent metal cations}

The crystal structures of $\left[\mathrm{Ni}(\mathrm{en})_{3}\right]\left[\mathrm{TiF}_{6}\right],\left[\mathrm{Cu}(\mathrm{en})_{2}\right]\left[\mathrm{TiF}_{6}\right]$, and $(\mathrm{Hpy})_{2}\left\{\mathrm{Cu}(\mathrm{py})_{4}\left(\mathrm{TiF}_{6}\right)_{2}\right\}$ were described [55]. The structure of $\left[\mathrm{Ni}(\mathrm{en})_{3}\right]\left[\mathrm{TiF}_{6}\right][55]$ is built up by isolated $\left[\mathrm{Ni}(\mathrm{en})_{3}\right]^{2+}$ complex cations and $\left[\mathrm{TiF}_{6}\right]^{2-}$ complex anions (Fig. 2). The bidentate en ligands coordinate the $\mathrm{Ni}^{2+}$ ion with formation of strongly distorted octahedral $\mathrm{NiN}_{6}$ units. The $\mathrm{Ni}-\mathrm{N}$ bond lengths are crystallographically equivalent at 2.101(5) $\AA$, whereas $\mathrm{N}-\mathrm{Ni}-\mathrm{N}$ cis- and trans-angles differ significantly from 90 and $180^{\circ}\left(79.4(3)-95.0\right.$ and $\left.169.2(5)^{\circ}\right)$.

Fig. 2 here

The $\left[\mathrm{TiF}_{6}\right]^{2-}$ complex anions comprise virtually regular octahedra with the Ti-F distance equal to $1.823(4) \AA$, which is somewhat longer than similar Ti-F distance $(1.796(5) \AA)$ in the octahedral $\left[\mathrm{TiF}_{6}\right]^{2-}$ anion of $\left[\mathrm{Ni}_{(}\left(\mathrm{H}_{2} \mathrm{O}\right)_{6}\right]\left[\mathrm{TiF}_{6}\right]$ [45]. Each $\left[\mathrm{TiF}_{6}\right]^{2-}$ anion is surrounded by three en

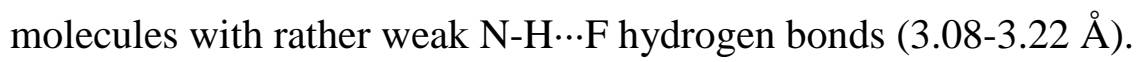

The crystal structure of $\left[\mathrm{Cu}(\mathrm{en})_{2}\right]\left[\mathrm{TiF}_{6}\right][55]$ is very similar to that of $\left[\mathrm{Cu}\left(\mathrm{H}_{2} \mathrm{O}\right)_{4}\right]\left[\mathrm{TiF}_{6}\right][47]$. It is formed by $\left[\mathrm{Cu}(\mathrm{en})_{2}\right]^{2+}$ complex cations and $\left[\mathrm{TiF}_{6}\right]^{2-}$ complex anions alternatively linked into polymeric chains, similar to the structural motif found in $\left[\mathrm{Cu}\left(\mathrm{H}_{2} \mathrm{O}\right)_{4}\right]\left[\mathrm{TiF}_{6}\right]$. The $\left[\mathrm{TiF}_{6}\right]^{2-}$ complex anion has a distorted octahedral structure with four short (1.746(5) $\AA$ ) and two long Ti-F bonds $(1.879(8) \AA)$ that are somewhat shorter than similar Ti-F bonds in $\left[\mathrm{Cu}\left(\mathrm{H}_{2} \mathrm{O}\right)_{4}\right]\left[\mathrm{TiF}_{6}\right](\mathrm{Table} 1)$. 
The longer Ti-F bonds are associated with $\mathrm{F}$ atoms that bridge to the cations resulting in polymeric chains. The $\left[\mathrm{Cu}(\mathrm{en})_{2}\right]^{2+}$ units are square-planar but form bonds to two $\mathrm{F}$ atoms of different $\left[\mathrm{TiF}_{6}\right]^{2-}$ anions forming significantly distorted octahedral $\mathrm{CuN}_{4} \mathrm{~F}_{2}$ groups. The unique $\mathrm{Cu}-\mathrm{N}$ bond length is 1.989 (7) $\AA$, whereas the distance to the bridging $\mathrm{F}$ atom is $2.430(8) \AA$.

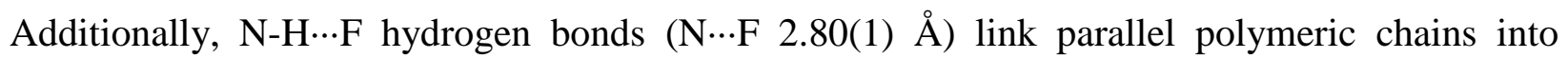
layers, that are further associated via $\mathrm{C}-\mathrm{H} \cdots \mathrm{F}$ bonds $(3.465(8) \AA)$ into a three-dimensional structure.

Trimeric cluster anions $\left\{\mathrm{Cu}(\mathrm{py})_{4}\left(\mathrm{TiF}_{6}\right)_{2}\right\}^{2-}$ and pyridinium cations $\mathrm{pyH}^{+}$form the crystal structure of $(\mathrm{pyH})_{2}\left\{\mathrm{Cu}(\mathrm{py})_{4}\left(\mathrm{TiF}_{6}\right)_{2}\right\}$ [55]. In the trimeric anion, the $\mathrm{Cu}$ atom is surrounded by four $\mathrm{N}$ atoms of four neutral pyridine molecules and two $\mathrm{F}$ atoms of $\mathrm{TiF}_{6}$ groups, thus forming the octahedral group $\mathrm{CuN}_{4} \mathrm{~F}_{2}$. The $\mathrm{Cu}-\mathrm{N}$ distances are equivalent at 2.025(3) $\AA$, whereas the $\mathrm{Cu}$ F bond lengths are 2.507(3) $\AA$. The $\mathrm{TiF}_{6}$ groups are octahedral as well. They are more distorted compared to the $\mathrm{CuN}_{4} \mathrm{~F}_{2}$ octahedra. Disordered $\mathrm{pyH}^{+}$cations form $\mathrm{N}-\mathrm{H} \cdots \mathrm{F}$ hydrogen bonds $\left(\mathrm{N} \cdots \mathrm{F} 2.976 \AA\right.$ ) with $\mathrm{F}$ atoms of the $\mathrm{TiF}_{6}$ octahedra linking the structural units into a threedimensional network.

In the structure of $\left[\mathrm{Cu}(\mathrm{py})_{4}\right]\left[\mathrm{TiF}_{6}\right] \cdot 3 \mathrm{H}_{2} \mathrm{O}[56], \mathrm{Cu}^{2+}$ ions coordinated by four $\mathrm{N}$ atoms of pyridine molecules form $\left[\mathrm{Cu}(\mathrm{py})_{4}\right]^{2+}$ complex cations with a $\mathrm{Cu}-\mathrm{N}$ distance of 2.02(1) $\mathrm{A}$ equal to the $\mathrm{Cu}-\mathrm{N}$ bond length in $(\mathrm{pyH})_{2}\left\{\mathrm{Cu}(\mathrm{py})_{4}\left(\mathrm{TiF}_{6}\right)_{2}\right\}$ [55]. The $\left[\mathrm{Cu}(\mathrm{py})_{4}\right]\left[\mathrm{TiF}_{6}\right] \cdot 3 \mathrm{H}_{2} \mathrm{O}$ structure also contains octahedral $\left[\mathrm{TiF}_{6}\right]^{2-}$ anions and lattice $\mathrm{H}_{2} \mathrm{O}$ molecules. The Ti-F bond lengths in the $\left[\mathrm{TiF}_{6}\right]^{2-}$ complex anion range from 1.86(1) to 1.87(1) $\AA$. Cations and anions alternate in linear polymeric chains through trans-bridging $\mathrm{F}$ atoms. The $\mathrm{Cu}-\mathrm{F}$ bond length in the chain is 2.52(1) $\AA$. The linear chains form channels containing $\mathrm{H}_{2} \mathrm{O}$ molecules that hydrogen bond with the $\mathrm{F}$ atoms. The $\mathrm{O} \cdots \mathrm{F}$ distances are to 2.76(2)-2.80(2) $\AA$.

In $\left[\mathrm{Cu}(\mathrm{pyz})\left(\mathrm{H}_{2} \mathrm{O}\right)_{2}\right]\left[\mathrm{TiF}_{6}\right]$ [57], the $\mathrm{Ti}$ atoms are surrounded by six almost equidistant fluorine atoms forming regular octahedral $\mathrm{TiF}_{6}$ groups. Two $\mathrm{F}$ atoms, two $\mathrm{H}_{2} \mathrm{O}$ molecules, and two $\mathrm{N}$ atoms of the pyz ligand coordinate the $\mathrm{Cu}^{2+}$ ions, thus forming distorted octahedral groups $\mathrm{CuF}_{2} \mathrm{~N}_{2} \mathrm{O}_{2}$. The $\mathrm{F}$ atoms occupy axial positions in the octahedron and are removed from the $\mathrm{Cu}$ atom at 2.353(2) $\AA$. Two trans $-\mathrm{H}_{2} \mathrm{O}$ molecules $\left(\mathrm{Cu}-\mathrm{H}_{2} \mathrm{O}\right.$ 1.947(2) $\AA$ ) and two $\mathrm{N}$ atoms from two bridging pyrazine molecules $(\mathrm{Cu}-\mathrm{N} 2.046(3)$ and 2.051(3) $\AA$ ) form the octahedral equatorial plane. The $\mathrm{TiF}_{6}$ octahedra are linked to $\mathrm{Cu}(\mathrm{pyz})\left(\mathrm{H}_{2} \mathrm{O}\right)_{2}$ groups via trans-F with forming zigzag - 
F-Cu-F-Ti-F- polymeric chains with a Cu-F-Ti angle of $140.16(9)^{\circ}$. Each polymeric chain is linked to six symmetrically equivalent adjacent chains through two $\mathrm{Cu}$-pyz bridges and four $\mathrm{Cu}-$ $\mathrm{O}-\mathrm{H} \cdots \mathrm{F}-\mathrm{Ti}$ hydrogen bonds. The result is the formation of polymeric layers. The O...F distances are 2.584(3) and 2.604(3) $\AA$ indicative of comparatively strong hydrogen bonds in the structure.

Complex $\left[\mathrm{Cu}\left(4,4^{\prime} \text {-bipy }\right)_{2}\left(\mathrm{H}_{2} \mathrm{O}\right)_{2}\right]^{2+}$ cations and $\left[\mathrm{TiF}_{6}\right]^{2-}$ anions comprise the $2 \mathrm{D}$ structure of $\left[\mathrm{Cu}\left(4,4^{\prime} \text {-bipy }\right)_{2}\left(\mathrm{H}_{2} \mathrm{O}\right)_{2}\right]\left[\mathrm{TiF}_{6}\right][58]$, which is similar to that of $\left[\mathrm{Cu}(\mathrm{pyz})\left(\mathrm{H}_{2} \mathrm{O}\right)_{2}\right]\left[\mathrm{TiF}_{6}\right]$ [57]. The oxygen atoms of $\mathrm{H}_{2} \mathrm{O}$ molecules in axial positions and four $\mathrm{N}$ atoms of 4,4'-bipy molecules in the equatorial plane form an elongated environment around the $\mathrm{Cu}$ atom. $\mathrm{The}_{2} \mathrm{O}$ molecules are separated from the $\mathrm{Cu}$ atom at 2.385(2) $\AA$, which is much longer than the $\mathrm{Cu}-\mathrm{OH}_{2}$ bond length $(1.947(2) \AA)$ in $\left[\mathrm{Cu}(\mathrm{pyz})\left(\mathrm{H}_{2} \mathrm{O}\right)_{2}\right]\left[\mathrm{TiF}_{6}\right]$ [57] where the coordinated $\mathrm{H}_{2} \mathrm{O}$ molecules are located in the octahedron's equatorial plane. The $\mathrm{Cu}-\mathrm{N}$ bond lengths in the cation are equal at 2.041(4) $\AA$. The $\mathrm{Cu}$ atoms linked to 4,4'-bipy through bridge-like ligands form 2D layers having square grids with angles of 88.5 and $91.5^{\circ}$. Each 2D layer lying in the (a-b)c and (b-a)c planes affords a double-interpenetration mode with formation of micropores of $c a .2 \AA \times 2 \AA$ directed along the $c$ axis. Isolated octahedral complex anions $\left[\mathrm{TiF}_{6}\right]^{2-}$ occupy the channels. The $\mathrm{TiF}_{6}$ octahedra interact with coordinated $\mathrm{H}_{2} \mathrm{O}$ molecules through $\mathrm{O}-\mathrm{H} \cdots \mathrm{F}$ hydrogen bonds with the $\mathrm{O} \cdots \mathrm{F}$ distances equal to 2.665(4) $\AA$.

The crystal structure of $\left[\mathrm{Cu}\left(4,4^{\prime} \text {-bipy }\right)_{2}\right]\left[\mathrm{TiF}_{6}\right] \quad[59]$, like that of $\left[\mathrm{Cu}\left(4,4^{\prime}-\right.\right.$ bipy $\left.)_{2}\left(\mathrm{H}_{2} \mathrm{O}\right)_{2}\right]\left[\mathrm{TiF}_{6}\right][58]$, is layered. It is formed by $\left[\mathrm{Cu}\left(4,4^{\prime} \text {-bipy }\right)_{2}\right]^{2+}$ complex cations and $\left[\mathrm{TiF}_{6}\right]^{2-}$ complex anions. The $\mathrm{Cu}$ atoms in $\left[\mathrm{Cu}\left(4,4^{\prime} \text {-bipy }\right)_{2}\right]^{2+}$ are coordinated by four $\mathrm{N}$ atoms of two 4,4'-bipy ligands. The $\mathrm{Cu}$ atom forms octahedral $\mathrm{CuF}_{2} \mathrm{~N}_{4}$ group through bonding to two $\mathrm{F}$ atoms of two different $\left[\mathrm{TiF}_{6}\right]^{2-}$ anions. All $\mathrm{Cu}-\mathrm{N}$ bond lengths in $\mathrm{CuF}_{2} \mathrm{~N}_{4}$ octahedron are equal to 2.025(3) $\AA$, whereas the $\mathrm{Cu}-\mathrm{F}$ distance is 2.343(3) $\AA$. In the $\mathrm{CuF}_{2} \mathrm{~N}_{4}$ octahedron, $\mathrm{F}$ atoms occupy axial positions, whereas the $\mathrm{N}$ atoms of $4,4^{\prime}$-bipy molecules form the equatorial plane. The $\left[\mathrm{TiF}_{6}\right]^{2-}$ anions are regular octahedra. The $\left[\mathrm{Cu}\left(4,4^{\prime}-\text { bipy }\right)_{2}\right]^{2+}$ cations and $\left[\mathrm{TiF}_{6}\right]^{2-}$ anions, are linked through $\mathrm{F}$ trans-atoms of alternating $\left[\mathrm{TiF}_{6}\right]^{2-}$ anions, giving rise to linear polymeric chains -F-Cu-F-Ti-F. Each polymeric chain is linked through $\mathrm{N}$ atoms of bridging 4,4'-bipy molecules with 4 similar chains with formation a 2D structure.

Cobalt(III) dioximates containing $\left[\mathrm{Co}(\mathrm{DH})_{2} \mathrm{~A}_{2}\right]^{+}$cations $\left(\mathrm{DH}^{-}=\right.$monodeprotonated anion of dimethylglyoxime, $\mathrm{A}=$ neutral monodentate ligand) and various fluoride complex anions 
$\left(\left[\mathrm{BF}_{4}\right]^{-},\left[\mathrm{BeF}_{4}\right]^{2-},\left[\mathrm{AlF}_{6}\right]^{3-},\left[\mathrm{SiF}_{6}\right]^{2-},\left[\mathrm{ZrF}_{6}\right]^{2-}\right.$ etc.) have been under intensive investigation during the last decade in view of their valuable biological properties [131-133]. A series of complex dioximates and mixed metal dioximates $\mathrm{Co}(\mathrm{III})$ containing thiourea and selenurea as neutral ligands and $\left[\mathrm{TiF}_{6}\right]^{2-}$ complex anions as counter-ions have also been structurally characterized (Table 1) [60-62].

The crystal structure of thiourea-containing dioximates $\mathrm{Co}(\mathrm{III})$ $\left[\mathrm{Co}\left(\mathrm{DH}_{2}\right)(\mathrm{D})(\mathrm{tu})_{2}\right]_{2}\left[\mathrm{TiF}_{6}\right] \cdot 2 \mathrm{dmf}, \quad\left[\mathrm{Co}(\mathrm{NioxH})_{2}\left(\mathrm{tu}_{2}\right]_{2}\left[\mathrm{TiF}_{6}\right] \cdot 2.25 \mathrm{H}_{2} \mathrm{O}, \quad\right.$ and $\left[\mathrm{Co}(\mathrm{DfgH})_{2}(\mathrm{tu})_{2}\right]_{2}\left[\mathrm{TiF}_{6}\right] \cdot 4 \mathrm{dmf} \cdot 1.5 \mathrm{H}_{2} \mathrm{O}$ were described [60]. These compounds have an ionic structure formed by $\left[\mathrm{Co}(\mathrm{III}) \mathrm{L}_{2}(\mathrm{tu})_{2}\right]^{+}$complex cations, $\left[\mathrm{TiF}_{6}\right]^{2-}$ anions, and solvate $\mathrm{dmf}$ and $\mathrm{H}_{2} \mathrm{O}$ molecules. Unlike cations found in $\left[\mathrm{Co}(\mathrm{NioxH})_{2}(\mathrm{tu})_{2}\right]_{2}\left[\mathrm{TiF}_{6}\right] \cdot 2.25 \mathrm{H}_{2} \mathrm{O}$ and $\left[\mathrm{Co}(\mathrm{DfgH})_{2}(\mathrm{tu})_{2}\right]_{2}\left[\mathrm{TiF}_{6}\right] \cdot 4 \mathrm{dmf} \cdot 1.5 \mathrm{H}_{2} \mathrm{O}$, in which the $\mathrm{Co}(\mathrm{III})$ atom is coordinated by two monodeprotonated dioxime ligands, the complex $\left[\mathrm{Co}\left(\mathrm{DH}_{2}\right)(\mathrm{D})(\mathrm{tu})_{2}\right]^{+}$cation in the structure of $\left[\mathrm{Co}\left(\mathrm{DH}_{2}\right)(\mathrm{D})(\mathrm{tu})_{2}\right]_{2}\left[\mathrm{TiF}_{6}\right] \cdot 2 \mathrm{dmf}$ contains one neutral (molecular) and one doubly deprotonated dimethylglyoxime ligand (D). The $\left[\mathrm{Co}(\mathrm{III}) \mathrm{L}_{2}(\mathrm{tu})_{2}\right]^{+}$cations have a trans-octahedral structure with L ligands in the equatorial plane and tu molecules in axial positions. The coordination polyhedron of the $\mathrm{Co}$ (III) atoms is formed by four $\mathrm{N}$ atoms of two L ligands and two $\mathrm{S}$ atoms of two coordinated tu molecules. The Co-N bond lengths (1.875(7)-1.923(8) Å) and Co-S distances (2.317(1)-2.321(2) $\AA$ ) are characteristic of those in the structures of tu-containing $\mathrm{Co}(\mathrm{III})$ dioximates [131-133]. In the $\left[\mathrm{TiF}_{6}\right]^{2-}$ complex anions, the Ti-F bond lengths range from 1.812(5) to $1.898(4) \AA$. Several $\mathrm{F}$ atoms of $\left[\mathrm{TiF}_{6}\right]^{2-}$ anions participate in formation of hydrogen bonds with $\mathrm{NH}_{2}$-groups of tu molecules coordinated by the $\mathrm{Co}(\mathrm{III})$ atom. The $\mathrm{N} \cdots \mathrm{F}$ hydrogen bond lengths range from $2.758(8)$ to $2.994(4) \AA$. Bonds of similar lengths are formed by $\mathrm{NH}_{2}$-groups of the oxime ligands as well. Stronger intramolecular O-H $\cdots \mathrm{O}$ hydrogen bonds are formed by ligand $\mathrm{OH}$ groups with oxime $\mathrm{O}$ atoms $(\mathrm{O} \cdots \mathrm{O} a v$. 2.535(3), 2.537(8), and 2.504(7) $\AA$, respectively). Through these bonds, pseudo-macrocycles are formed in the complex ion's equatorial plane.

The crystal structure of $\left[\mathrm{Co}(\mathrm{DH})_{2}(\mathrm{seu})_{1.75}(\mathrm{Se}-\mathrm{seu})_{0.25}\right]_{2}\left[\mathrm{TiF}_{6}\right] \cdot \mathrm{H}_{2} \mathrm{O}$ [61] displays some similarity to $\left[\mathrm{Co}(\mathrm{NioxH})_{2}(\mathrm{tu})_{2}\right]_{2}\left[\mathrm{TiF}_{6}\right] \cdot 2.25 \mathrm{H}_{2} \mathrm{O}$ and $\left[\mathrm{Co}(\mathrm{DfgH})_{2}(\mathrm{tu})_{2}\right]_{2}\left[\mathrm{TiF}_{6}\right] \cdot 4 \mathrm{dmf} \cdot 1.5 \mathrm{H}_{2} \mathrm{O}$. The structure of $\left[\mathrm{Co}(\mathrm{DH})_{2}(\mathrm{seu})_{1.75}(\mathrm{Se}-\mathrm{seu})_{0.25}\right]_{2}\left[\mathrm{TiF}_{6}\right] \cdot \mathrm{H}_{2} \mathrm{O}$ contains disordered complex cations, $\left[\mathrm{TiF}_{6}\right]^{2-}$ complex anions, and crystallization $\mathrm{H}_{2} \mathrm{O}$ molecules. The complex cations 
$\left[\mathrm{Co}(\mathrm{DH})_{2}(\mathrm{seu})_{1.75}(\mathrm{Se}-\mathrm{seu})_{0.25}\right]^{+}$have an octahedral structure. The coordination polyhedron of the $\mathrm{Co}$ (III) atom is composed of four $\mathrm{N}$ atoms of two coordinated dimethylglyoxime monoanions $\left(\mathrm{DH}^{-}\right)$forming the octahedron's equatorial plane. The Se atoms of selenurea occupy the axial positions. Unlike dioximate-tu complex in which both axial positions are occupied by tu ligands, in $\left[\mathrm{Co}(\mathrm{DH})_{2}(\mathrm{seu})_{1.75}(\mathrm{Se}-\mathrm{seu})_{0.25}\right]_{2}\left[\mathrm{TiF}_{6}\right] \cdot \mathrm{H}_{2} \mathrm{O}$ the axial positions are occupied by different ligands - a coordinated seu molecule and an Se-seu ligand. The latter is an oxidized form of the seu molecule.

The Co- $\mathrm{N}$ distances in $\left[\mathrm{Co}(\mathrm{DH})_{2}(\mathrm{seu})_{1.75}(\mathrm{Se}-\mathrm{seu})_{0.25}\right]_{2}\left[\mathrm{TiF}_{6}\right] \cdot \mathrm{H}_{2} \mathrm{O}(1.885(6)-1.890(6) \AA)$ are similar to those in the structures of other dioximates, and the Co-Se bond lengths range between 2.41(1) and 2.49(3) $\AA$. Monodeprotonated chelate $\mathrm{DH}^{-}$anions form two rather strong intramolecular $\mathrm{O}-\mathrm{H} \cdots \mathrm{O}$ hydrogen bonds with $\mathrm{O} \cdots \mathrm{O}$ distances of 2.529(8) and 2.505(9) $\AA$. In the octahedral $\left[\mathrm{TiF}_{6}\right]^{2-}$ anions, the Ti-F bond lengths are in the ranges 1.73(2)-1.97(3) for Ti(1) and 1.80(2)-1.82(2) $\AA$ for Ti(2). All $\mathrm{F}$ atoms of the anions are involved in the system of $\mathrm{N}-\mathrm{H} \cdots \mathrm{F}$

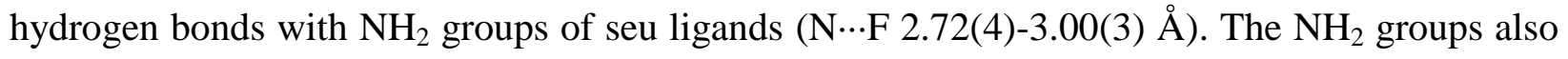
form $\mathrm{N}-\mathrm{H} \cdots \mathrm{O}$ hydrogen bonds with the oxime $\mathrm{O}$ atoms and those of $\mathrm{H}_{2} \mathrm{O}$ molecules. Electrostatic interactions and hydrogen bonds link the structural units into a three-dimensional structure.

The crystal structures of mixed metal $\alpha$-dioximates $\left[\mathrm{Co}(\mathrm{DH})_{2}(\mathrm{tu})_{2}\right]\left[\mathrm{Rh}(\mathrm{tu})_{6}\right]\left[\mathrm{TiF}_{6}\right]_{2} \cdot 2 \mathrm{H}_{2} \mathrm{O}$ and $\left[\mathrm{Co}(\mathrm{NioxH})_{2}(\mathrm{tu})_{2}\right]_{2}\left[\mathrm{Rh}(\mathrm{tu})_{5} \mathrm{Cl}\right]\left[\mathrm{TiF}_{6}\right]_{2} \cdot \mathrm{CH}_{3} \mathrm{OH} \cdot 3 \mathrm{H}_{2} \mathrm{O}$ containing two different octahedral complex cations have been described [62]. The Co(III) cations in these two compounds have an octahedral structure, just like in $\left[\mathrm{Co}\left(\mathrm{DH}_{2}\right)(\mathrm{D})(\mathrm{tu})_{2}\right]_{2}\left[\mathrm{TiF}_{6}\right] \cdot 2 \mathrm{dmf}$, $\left[\mathrm{Co}(\mathrm{NioxH})_{2}(\mathrm{tu})_{2}\right]_{2}\left[\mathrm{TiF}_{6}\right] \cdot 2.25 \mathrm{H}_{2} \mathrm{O}, \quad$ and $\quad\left[\mathrm{Co}(\mathrm{DfgH})_{2}\left(\mathrm{tu}_{2}\right]_{2}\left[\mathrm{TiF}_{6}\right] \cdot 4 \mathrm{dmf} \cdot 1.5 \mathrm{H}_{2} \mathrm{O}\right.$. Two monodeprotonated $\alpha$-dioxime ligands $\mathrm{DH}^{-}$and $\mathrm{NioxH}^{-}$are located in the octahedron's equatorial plane. The tu ligands occupy the axial positions. Interatomic distances in $\left[\mathrm{Co}(\mathrm{DH})_{2}(\mathrm{tu})_{2}\right]^{+}$and $\left[\mathrm{Co}(\mathrm{NioxH})_{2}(\mathrm{tu})_{2}\right]^{+}$cations of the two structures are similar to those found in $\left[\mathrm{Co}\left(\mathrm{DH}_{2}\right)(\mathrm{D})(\mathrm{tu})_{2}\right]_{2}\left[\mathrm{TiF}_{6}\right] \cdot 2 \mathrm{dmf}, \quad\left[\mathrm{Co}(\mathrm{NioxH})_{2}(\mathrm{tu})_{2}\right]_{2}\left[\mathrm{TiF}_{6}\right] \cdot 2.25 \mathrm{H}_{2} \mathrm{O}, \quad$ and $\left[\mathrm{Co}(\mathrm{DfgH})_{2}(\mathrm{tu})_{2}\right]_{2}\left[\mathrm{TiF}_{6}\right] \cdot 4 \mathrm{dmf} \cdot 1.5 \mathrm{H}_{2} \mathrm{O}$. The $\mathrm{Rh}(\mathrm{III})$ atoms do not form coordination bonds with $\alpha$-dioxime ligands. $A s$ in the structure of $\left[\mathrm{Co}\left(\mathrm{DH}_{2}\right)(\mathrm{D})(\mathrm{tu})_{2}\right]_{2}\left[\mathrm{TiF}_{6}\right] \cdot 2 \mathrm{dmf}$, $\left[\mathrm{Co}(\mathrm{NioxH})_{2}(\mathrm{tu})_{2}\right]_{2}\left[\mathrm{TiF}_{6}\right] \cdot 2.25 \mathrm{H}_{2} \mathrm{O}$, and $\left[\mathrm{Co}(\mathrm{DfgH})_{2}\left(\mathrm{tu}_{2}\right]_{2}\left[\mathrm{TiF}_{6}\right] \cdot 4 \mathrm{dmf} \cdot 1.5 \mathrm{H}_{2} \mathrm{O}\right.$, the $\mathrm{F}$ atoms of the $\quad\left[\mathrm{TiF}_{6}\right]^{2-}$ anions in $\left[\mathrm{Co}(\mathrm{DH})_{2}(\mathrm{tu})_{2}\right]\left[\mathrm{Rh}(\mathrm{tu})_{6}\right]\left[\mathrm{TiF}_{6}\right]_{2} \cdot 2 \mathrm{H}_{2} \mathrm{O}$ and $\left[\mathrm{Co}(\mathrm{NioxH})_{2}(\mathrm{tu})_{2}\right]_{2}\left[\mathrm{Rh}(\mathrm{tu})_{5} \mathrm{Cl}\right]\left[\mathrm{TiF}_{6}\right]_{2} \cdot \mathrm{CH}_{3} \mathrm{OH} \cdot 3 \mathrm{H}_{2} \mathrm{O}$ participate in formation of a branched 
system of hydrogen bonds with $\mathrm{NH}_{2}$ donor groups of tu molecules combining the crystal units in a 3D network.

\subsection{Dimeric structures}

\subsubsection{Vertex-bridged dimeric fluoridotitanates $(I V)$}

Isolated octahedral $\mathrm{TiF}_{6}$ groups can be linked via vertex- or edge-sharing into dimeric, oligomeric, or polymeric formations. As compared to the crystal structures of monomeric fluoride complexes, those of dimeric, oligomeric, and polymeric fluoride complexes of titanium(IV) are studied insufficiently. Many types of this group of fluoridotitanates(IV) are represented by just one or few structural studies.

Tang, Dadachov, and Zou [63] reported the synthesis and investigation of the crystal structure of dimeric fluoride complex of titanium(IV) - dipyridinium-oxonium undecafluoridodititanate(IV) monohydrate, $\left(\mathrm{C}_{5} \mathrm{H}_{5} \mathrm{NH}\right)_{2}\left(\mathrm{H}_{3} \mathrm{O}\right)\left[\mathrm{Ti}_{2} \mathrm{~F}_{11}\right] \cdot \mathrm{H}_{2} \mathrm{O}$. The structure is composed of dimeric complex anions $\left[\mathrm{Ti}_{2} \mathrm{~F}_{11}\right]^{3-}$, statistically disordered protonated pyridinium cations, and disordered $\mathrm{H}_{3} \mathrm{O}^{+}$ions/ $\mathrm{H}_{2} \mathrm{O}$ molecules (Fig. 3). The dimeric $\left[\mathrm{Ti}_{2} \mathrm{~F}_{11}\right]^{3-}$ anion is composed of two octahedral $\mathrm{TiF}_{6}$ groups linked through a fluorine vertex. The $\mathrm{C}_{5} \mathrm{H}_{5} \mathrm{NH}^{+}$and $\mathrm{H}_{3} \mathrm{O}^{+}$cations are located between the anions, thus compensating their charge. In the dimeric complex anion, the Ti- $\mathrm{F}_{\text {terminal }}$ lengths range from 1.776(2) to 1.880(2) $\AA$, while the distance from Ti atoms to the bridging $\mathrm{F}$ atom is longer at 1.9732(10) $\AA$.

Fig. 3 here

The $\mathrm{H}_{3} \mathrm{O}^{+}$cations participate in formation of rather strong hydrogen bonds with both $\mathrm{F}$ atoms of octahedral $\mathrm{TiF}_{6}$ groups and $\mathrm{O}$ atoms of $\mathrm{H}_{3} \mathrm{O}^{+}$cations $/ \mathrm{H}_{2} \mathrm{O}$ molecules. Two O-H $\cdots \mathrm{F}$ hydrogen bonds are directed to $\mathrm{F}$ atoms of $\mathrm{TiF}_{6}$ octahedra $(\mathrm{O} \cdots \mathrm{F} 2.634(3)$ and $2.593(3) \AA)$. The third rather strong $\mathrm{O}-\mathrm{H} \cdots \mathrm{O}$ hydrogen bond $\left(d_{\mathrm{O} \cdots \mathrm{O}}=2.452(5) \AA\right)$ is formed by $\mathrm{H}_{3} \mathrm{O}^{+}$cations with the $\mathrm{O}$ atom of the adjacent $\mathrm{H}_{3} \mathrm{O}^{+}$cation/ $\mathrm{H}_{2} \mathrm{O}$ molecule. Hydrogen bonds link the dimeric 
complex anions, $\mathrm{C}_{5} \mathrm{H}_{5} \mathrm{NH}^{+}$and $\mathrm{H}_{3} \mathrm{O}^{+}$cations and $\mathrm{H}_{2} \mathrm{O}$ molecules into a three-dimensional network.

The disordered structure of $\left(\mathrm{NMe}_{4}\right)_{4}\left[\mathrm{Ti}_{2} \mathrm{~F}_{11}\right]\left[\mathrm{Ti}_{2} \mathrm{~F}_{9}\left(\mathrm{H}_{2} \mathrm{O}\right)_{2}\right]$ is formed by complex anions $\left[\mathrm{Ti}_{2} \mathrm{~F}_{11}\right]^{3-}$ and $\left[\mathrm{Ti}_{2} \mathrm{~F}_{9}\left(\mathrm{H}_{2} \mathrm{O}\right)_{2}\right]^{-}$at 1:1 ratio and tetramethylammonium $\mathrm{NMe}_{4}{ }^{+}$cations, each of them with an occupancy factor of 0.5 [64]. The dimeric $\left[\mathrm{Ti}_{2} \mathrm{~F}_{11}\right]^{3-}$ anion is composed of distorted octahedral $\mathrm{TiF}_{6}$ groups linked into dimers by common bridging $\mathrm{F}$ atom. The bridging $\mathrm{F}$ atoms located on the two-fold axis forms symmetric dimers. The length of the Ti- $F_{\text {bridging }}$ bond is 1.9927(1) $\AA$, which is close to the Ti- $\mathrm{F}_{\text {bridging }}$ bond of $1.9732(10) \AA$ in the dimeric $\left[\mathrm{Ti}_{2} \mathrm{~F}_{11}\right]^{3-}$ anion found in $\left(\mathrm{C}_{5} \mathrm{H}_{5} \mathrm{NH}\right)_{2}\left(\mathrm{H}_{3} \mathrm{O}\right)\left[\mathrm{Ti}_{2} \mathrm{~F}_{11}\right] \cdot \mathrm{H}_{2} \mathrm{O}$ [63]. The Ti- $\mathrm{F}_{\text {terminal }}$ bond lengths in $\left[\mathrm{Ti}_{2} \mathrm{~F}_{11}\right]^{3-}$ anion have somewhat larger values (1.811(2)-1.903(3) $\AA$ ) than similar ones in the $\left[\mathrm{Ti}_{2} \mathrm{~F}_{11}\right]^{3-}$ anion (1.776(2)-1.880(2) $\AA$ ) of the $\left(\mathrm{C}_{5} \mathrm{H}_{5} \mathrm{NH}\right)_{2}\left(\mathrm{H}_{3} \mathrm{O}\right)\left[\mathrm{Ti}_{2} \mathrm{~F}_{11}\right] \cdot \mathrm{H}_{2} \mathrm{O}$ structure (Table 1). The $\left[\mathrm{Ti}_{2} \mathrm{~F}_{11}\right]^{3-}$ anions form virtually linear polymeric bands through hydrogen bonding. The $\mathrm{NMe}_{4}{ }^{+}$ cations are located between the polymeric chains. The structure of the dimeric complex anion $\left[\mathrm{Ti}_{2} \mathrm{~F}_{9}\left(\mathrm{H}_{2} \mathrm{O}\right)_{2}\right]^{-}$will be considered in section 3.1.2.

The isolated dimeric $\left[\mathrm{Ti}_{2} \mathrm{~F}_{11}\right]^{3-}$ complex anions are composed of two octahedral $\mathrm{TiF}_{6}$ units linked through a common fluorine vertex as found in the crystal structure of $[\mathrm{ImH}]_{3}\left[\mathrm{Ti}_{2} \mathrm{~F}_{11}\right]$ [41]. In contrast to $\left(\mathrm{C}_{5} \mathrm{H}_{5} \mathrm{NH}\right)_{2}\left(\mathrm{H}_{3} \mathrm{O}\right)\left[\mathrm{Ti}_{2} \mathrm{~F}_{11}\right] \cdot \mathrm{H}_{2} \mathrm{O}$ [63], which contains only one $\left[\mathrm{Ti}_{2} \mathrm{~F}_{11}\right]^{3-}$ unit, $[\mathrm{ImH}]_{3}\left[\mathrm{Ti}_{2} \mathrm{~F}_{11}\right]$ has three crystallographically independent anions of different conformations. The ranges of $\mathrm{Ti}-\mathrm{F}_{\text {terminal }}$ and $\mathrm{Ti}-\mathrm{F}_{\text {bridging }}$ bond lengths for independent $\mathrm{Ti}(1)$, $\mathrm{Ti}(2)$, and $\mathrm{Ti}(3)$ dimeric complex $\left[\mathrm{Ti}_{2} \mathrm{~F}_{11}\right]^{3-}$ anions are comparable to the corresponding bond lengths in $\left(\mathrm{C}_{5} \mathrm{H}_{5} \mathrm{NH}\right)_{2}\left(\mathrm{H}_{3} \mathrm{O}\right)\left[\mathrm{Ti}_{2} \mathrm{~F}_{11}\right] \cdot \mathrm{H}_{2} \mathrm{O}$ (Table 1). The structure contains two types of ordered and one type of disordered $\mathrm{ImH}^{+}$cations. The $\mathrm{ImH}^{+}$cations bound to the dimeric $\left[\mathrm{Ti}_{2} \mathrm{~F}_{11}\right]^{3-}$ anions form a three-dimensional network of $\mathrm{N}-\mathrm{H} \cdots \mathrm{F}$ and $\mathrm{C}-\mathrm{H} \cdots \mathrm{F}$ hydrogen bonds. The $\mathrm{N} \cdots \mathrm{F}$ distances are in the range from 2.743(3) to 2.925(9) $\AA$. The hydrogen bonds formed by $\mathrm{C}-\mathrm{H}$ are weaker and predominantly larger than $3.00 \AA$. The cations and anions are linked into a three-dimensional network by electrostatic interactions and a system of hydrogen bonds.

\subsubsection{Edge-bridged dimeric fluoridotitanates(IV)}

Two crystal structures with edge-bridged dimeric complex anions composed of two octahedral $\mathrm{TiF}_{6}$ groups linked by a double fluoride bridging bond were investigated. Akutsu et 
al. [65] reported a structural study of the dimeric fluoride complex tris(tetramethyltetrathiafulvalene) di- $\mu$-fluoro-bis[tetrafluoridotitanate(IV)], $\left(\mathrm{C}_{10} \mathrm{H}_{12} \mathrm{~S}_{4}\right)_{3}\left[\mathrm{Ti}_{2} \mathrm{~F}_{10}\right.$ ] $\left((\mathrm{TMTTF})_{3}\left[\mathrm{Ti}_{2} \mathrm{~F}_{10}\right]\right)$. The centrosymmetric unit cell consists of the tetramethyltetrathiafulvalene cations and dimeric $\left[\mathrm{Ti}_{2} \mathrm{~F}_{10}\right]^{2-}$ complex anions formed by edge-shared $\mathrm{TiF}_{6}$ octahedra. All of the cations are parallel, form a trimeric structure, and extend along the $a$ axis. Since the $\left[\mathrm{Ti}_{2} \mathrm{~F}_{10}\right]^{2-}$ anion carries a charge of -2 , the TMTTF trimer has an average charge of +2 , giving an average charge of one TMTTF cation of $+2 / 3$.

The $\left[\mathrm{Ti}_{2} \mathrm{~F}_{10}\right]^{2-}$ anions are located on the crystallographic inversion center. Six $\mathrm{F}$ atoms, two of which acting as bridging ligands are coordinated to each octahedral Ti atom. Due to bridging bonds, the $\mathrm{TiF}_{6}$ groups are significantly distorted. The $\mathrm{Ti}-\mathrm{F}_{\text {terminal }}$ bond lengths range from $1.781(3)$ to $1.822(2) \AA$, the Ti-F bridging bonds are significantly longer $(2.024(2) \AA)$. The shortest Ti- $\mathrm{F}_{\text {terminal }}$ bonds (1.781(3) and 1.794(3) $\AA$ ) in the octahedron are located trans to the bridging F atoms. The $\mathrm{C}_{10} \mathrm{H}_{12} \mathrm{~S}_{4}$ cations have no typical donor centers $(\mathrm{N}-\mathrm{H}, \mathrm{O}-\mathrm{H})$ capable of forming hydrogen bonds with the $\mathrm{F}$ atoms of the dimeric anion. Weak contacts are realized by then $\mathrm{C}-\mathrm{H}$

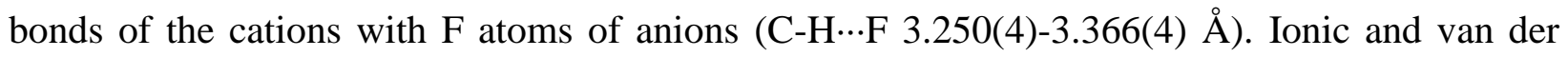
Waals interactions link tetramethyltetrathiafulvalene cations and $\left[\mathrm{Ti}_{2} \mathrm{~F}_{10}\right]^{2-}$ into a threedimensional network.

Fig. 4 here

The crystal structure of $\left(\mathrm{C}_{4} \mathrm{H}_{10} \mathrm{~N}_{2} \mathrm{H}_{2}\right)\left[\mathrm{Ti}_{2} \mathrm{~F}_{10}\right] \cdot 2 \mathrm{H}_{2} \mathrm{O}$ is built up by $\left(\mathrm{C}_{4} \mathrm{H}_{10} \mathrm{~N}_{2} \mathrm{H}_{2}\right)^{2+}$ cations, dimeric $\left[\mathrm{Ti}_{2} \mathrm{~F}_{10}\right]^{2-}$ complex anions composed of two edge-shared octahedral $\mathrm{TiF}_{6}$ groups, and $\mathrm{H}_{2} \mathrm{O}$ molecules (Fig. 4) [66]. Geometric characteristics of dimeric $\left[\mathrm{Ti}_{2} \mathrm{~F}_{10}\right]^{2-}$ anions in the structure are essentially different to those for $\left[\mathrm{Ti}_{2} \mathrm{~F}_{10}\right]^{2-}$ anions in $\left(\mathrm{C}_{10} \mathrm{H}_{12} \mathrm{~S}_{4}\right)_{3}\left[\mathrm{Ti}_{2} \mathrm{~F}_{10}\right]$ [65]. Unlike

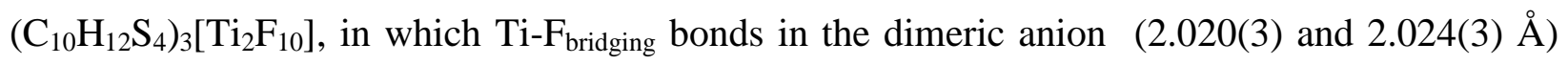
are significantly longer than $\quad \mathrm{Ti}^{-} \mathrm{F}_{\text {terminal }}$ bonds $(1.781(3)-1.822(3) \quad \AA)$ in $\left(\mathrm{C}_{4} \mathrm{H}_{10} \mathrm{~N}_{2} \mathrm{H}_{2}\right)\left[\mathrm{Ti}_{2} \mathrm{~F}_{10}\right] \cdot 2 \mathrm{H}_{2} \mathrm{O}$ the Ti- $\mathrm{F}_{\text {terminal }}$ bonds (1.898(2)-1.949(2) $\AA$ ) are somewhat longer than Ti- $\mathrm{F}_{\text {bridging }}$ bonds $\left(1.859(2), 1.876(2) \AA\right.$ ). This is caused by participation of all $\mathrm{F}_{\text {terminal }}$ atoms of the dimeric anion in formation of strong hydrogen bonds with $\left(\mathrm{C}_{4} \mathrm{H}_{10} \mathrm{~N}_{2} \mathrm{H}_{2}\right)^{2+}$ cations donor N-H groups and $\mathrm{O}-\mathrm{H}$ groups of $\mathrm{H}_{2} \mathrm{O}$ molecules. Each $\mathrm{F}$ atom of the dimeric $\left[\mathrm{Ti}_{2} \mathrm{~F}_{10}\right]^{2-}$ anion 
participates in formation of two hydrogen bonds. Comparatively strong $\mathrm{O}-\mathrm{H} \cdots \mathrm{F}$ hydrogen bonds are formed by $\mathrm{O}-\mathrm{H}$ groups of $\mathrm{H}_{2} \mathrm{O}$ molecules with $\mathrm{F}$ atoms of the dimer (2.671(3) and 2.732 (3) $\AA$ ), thus linking them into inorganic layers with $\left(\mathrm{C}_{4} \mathrm{H}_{10} \mathrm{~N}_{2} \mathrm{H}_{2}\right)^{2+}$ cations in between. Hydrogen bonds $\mathrm{N}-\mathrm{H} \cdots \mathrm{F}$ formed by groups of $\mathrm{N}-\mathrm{H}$ cations with $\mathrm{F}$ atoms of dimeric anions (2.682(3)2.927(3) $\AA$ ) are rather strong as well. The system of hydrogen bonds links cations, dimeric complex anions, and $\mathrm{H}_{2} \mathrm{O}$ molecules into a three-dimensional network.

\subsection{Oligomeric structures}

Oligomeric fluoride complexes of titanium(IV) are known that exhibit isolated tetrameric, pentameric, and octameric complex anions.

\subsubsection{Fluoridotitanates(IV) with tetrameric complex anions}

Isolated tetrameric $\left[\mathrm{Ti}_{4} \mathrm{~F}_{18}\right]^{2-}$ complex anions were observed in the crystal structures of $\left[\mathrm{TiF}_{2}\left([15]\right.\right.$ crown-5)][Ti $\left.\mathrm{F}_{18}\right] \cdot 0.5 \mathrm{MeCN}$ [67], $\left(\mathrm{NMe}_{4}\right)_{2}\left[\mathrm{Ti}_{4} \mathrm{~F}_{18}\right]$, and $\left(\mathrm{Ph}_{4} \mathrm{P}_{2}\left[\mathrm{Ti}_{4} \mathrm{~F}_{18}\right]\right.$ [68], (o$\left.\mathrm{C}_{6} \mathrm{H}_{4}\left(\mathrm{PPh}_{2} \mathrm{H}\right)_{2}\right)\left[\mathrm{Ti}_{4} \mathrm{~F}_{18}\right]$ [69], [ $\left[\mathrm{XeF}_{5}\right]_{3}\left[\mathrm{Ti}_{4} \mathrm{~F}_{19}\right][70], \beta-(\mathrm{ImH})_{4}\left[\mathrm{Ti}_{4} \mathrm{~F}_{20}\right]$, and $\alpha-(\mathrm{ImH})_{4}\left[\mathrm{Ti}_{4} \mathrm{~F}_{20}\right]$ [41].

The compound $\left[\mathrm{TiF}_{2}\left([15]\right.\right.$ crown-5)][ $\left.\mathrm{Ti}_{4} \mathrm{~F}_{18}\right] \cdot 0.5 \mathrm{MeCN}$ is composed of $\left[\mathrm{TiF}_{2}([15]\right.$ crown5) $]^{2+}$ cations isolated by tetrameric $\left[\mathrm{Ti}_{4} \mathrm{~F}_{18}\right]^{2-}$ complex anions and $\mathrm{MeCN}$ solvent molecules [67]. Tetrameric $\left[\mathrm{Ti}_{4} \mathrm{~F}_{18}\right]^{2-}$ anions are formed by four octahedral $\mathrm{TiF}_{6}$ groups linked to each other through three cis-F-atoms. Among the $18 \mathrm{~F}$ atoms in the $\left[\mathrm{Ti}_{4} \mathrm{~F}_{18}\right]^{2-}$ anion, six act as bridging ligands. The $\left[\mathrm{Ti}_{4} \mathrm{~F}_{18}\right]^{2-}$ anions have $T_{\mathrm{d}}$ symmetry with $\mathrm{Ti}$ atoms located at the corners of a tetrahedron. The average lengths of terminal and bridging Ti-F bonds in the $\left[\mathrm{Ti}_{4} \mathrm{~F}_{18}\right]^{2-}$ anion are 1.768 and $1.987 \AA$ respectively. A branched system of C-H $\cdots$ F hydrogen bonds (C...F 3.113(6)3.498(6) $\AA$ ) and ionic interactions link the structural elements into a three-dimensional network.

The structures of $\left(\mathrm{NMe}_{4}\right)_{2}\left[\mathrm{Ti}_{4} \mathrm{~F}_{18}\right]$ and $\left(\mathrm{Ph}_{4} \mathrm{P}\right)_{2}\left[\mathrm{Ti}_{4} \mathrm{~F}_{18}\right]$ [68] are ionic, being built up of $\mathrm{NMe}_{4}{ }^{+}$and $\mathrm{Ph}_{4} \mathrm{P}^{+}$cations and isolated $\left[\mathrm{Ti}_{4} \mathrm{~F}_{18}\right]^{2-}$ complex anions having the structure identical to that of the tetrameric anion in $\left[\mathrm{TiF}_{2}\left([15]\right.\right.$ crown-5)][Ti $\left.\mathrm{Ti}_{18}\right] \cdot 0.5 \mathrm{MeCN}[67]$. Four $\mathrm{TiF}_{6}$ octahedra linked through vertices form a tetrahedral group with $\mathrm{Ti}$ atoms in the vertices (Fig. 5). The Ti atoms are linked to each other by six bridging fluorine atoms and each is capped by three terminal fluorine atoms. 
Fig. 5 here

The lengths of Ti- $\mathrm{F}_{\text {terminal }}$ and Ti- $\mathrm{F}_{\text {bridging }}$ bonds in the $\left(\mathrm{NMe}_{4}\right)_{2}\left[\mathrm{Ti}_{4} \mathrm{~F}_{18}\right]$ and $\left(\mathrm{Ph}_{4} \mathrm{P}_{2}\left[\mathrm{Ti}_{4} \mathrm{~F}_{18}\right]\right.$ structures are in the same range as in the structure of $\left[\mathrm{TiF}_{2}\left([15]\right.\right.$ crown-5)][Ti $\left.{ }_{4} \mathrm{~F}_{18}\right] \cdot 0.5 \mathrm{MeCN}$ (Table 1). In the $\left(\mathrm{NMe}_{4}\right)_{2}\left[\mathrm{Ti}_{4} \mathrm{~F}_{18}\right]$ and $\left(\mathrm{Ph}_{4} \mathrm{P}_{2}\left[\mathrm{Ti}_{4} \mathrm{~F}_{18}\right]\right.$ structures, just like in that of $\left[\mathrm{TiF}_{2}\left([15]\right.\right.$ crown-5)][ $\left.\mathrm{Ti}_{4} \mathrm{~F}_{18}\right] \cdot 0.5 \mathrm{MeCN}$, the $\mathrm{C}-\mathrm{H}$ groups of cations form hydrogen bonds with $\mathrm{F}$ atoms of $\left[\mathrm{Ti}_{4} \mathrm{~F}_{18}\right]^{2-}$ anions that are very weak (3.220-3.406 $\AA$ in $\left(\mathrm{NMe}_{4}\right)_{2}\left[\mathrm{Ti}_{4} \mathrm{~F}_{18}\right]$ and 3.091-3.428 $\AA$ in $\left.\left(\mathrm{Ph}_{4} \mathrm{P}\right)_{2}\left[\mathrm{Ti}_{4} \mathrm{~F}_{18}\right]\right)$. Isolated tetrameric complex anions $\left[\mathrm{Ti}_{4} \mathrm{~F}_{18}\right]^{2-}$, whose dimensions are in good agreement with those of $\mathrm{A}_{2}\left[\mathrm{Ti}_{4} \mathrm{~F}_{18}\right]\left(\mathrm{A}=\mathrm{NMe}_{4}{ }^{+}, \mathrm{Ph}_{4} \mathrm{P}^{+}\right)$data [60], are present in the crystal structure of $\left[o-\mathrm{C}_{6} \mathrm{H}_{4}\left(\mathrm{PPh}_{2} \mathrm{H}\right)_{2}\right]\left[\mathrm{Ti}_{4} \mathrm{~F}_{18}\right]$ as well [69].

The structure of $\left[\mathrm{XeF}_{5}\right]_{3}\left[\mathrm{Ti}_{4} \mathrm{~F}_{19}\right]$ [70] consists of $\left[\mathrm{XeF}_{5}\right]^{+}$cations and isolated tetrameric $\left[\mathrm{Ti}_{4} \mathrm{~F}_{19}\right]^{3-}$ anions. Unlike the $\left[\mathrm{Ti}_{4} \mathrm{~F}_{18}\right]^{2-}$ anions containing just one type of $\mu_{3}-\mathrm{TiF}_{6}$ octahedra, sharing three vertices with three other $\mathrm{TiF}_{6}$ octahedra, the $\left[\mathrm{Ti}_{4} \mathrm{~F}_{19}\right]^{3-}$ anions contain two types of $\mathrm{TiF}_{6}$ octahedra with both $\mu_{3}-\mathrm{TiF}_{6}$ and $\mu_{2}-\mathrm{TiF}_{6}$. Two $\mu_{3}-\mathrm{TiF}_{6}$ octahedra share a common vertex and are bridged by two $\mu_{2}-\mathrm{TiF}_{6}$ units forming a tetrameric $\left[\mathrm{Ti}_{4} \mathrm{~F}_{19}\right]^{3-}$ anion. The Ti- $\mathrm{F}_{\text {terminal }}$ (1.747(5)-1.839(5) $\AA$ ) and Ti- $\mathrm{F}_{\text {bridging }}(1.935(4)-2.044(4) \AA)$ bond lengths in $\left[\mathrm{Ti}_{4} \mathrm{~F}_{19}\right]^{3-}$ are comparable to the respective bond lengths in $\left[\mathrm{Ti}_{4} \mathrm{~F}_{18}\right]^{2-}$ (Table 1).

Crystal structures of two modifications of $(\mathrm{ImH})_{4}\left[\mathrm{Ti}_{4} \mathrm{~F}_{20}\right]$ [41] were studied. $\beta$ $(\operatorname{ImH})_{4}\left[\mathrm{Ti}_{4} \mathrm{~F}_{20}\right]$ crystallizes in the monoclinic symmetry, while $\alpha-(\operatorname{ImH})_{4}\left[\mathrm{Ti}_{4} \mathrm{~F}_{20}\right]$ is triclinic. The crystal structures are composed of protonated imidazolium, $\mathrm{ImH}^{+}$cations and tetrameric $\left[\mathrm{Ti}_{4} \mathrm{~F}_{20}\right]^{4-}$ complex anions formed by four $\mathrm{TiF}_{6}$ octahedra, which share two cis-vertices. Each titanium atom in $\left[\mathrm{Ti}_{4} \mathrm{~F}_{20}\right]^{4-}$ is coordinated by two bridging and four terminal fluorine atoms. The Ti- $\mathrm{F}_{\text {terminal }}$ and Ti- $\mathrm{F}_{\text {bridging }}$ bond lengths in $\beta$ - and $\alpha$-modifications are comparable to each other (Table 1). In the $\beta$ - and $\alpha$-(ImH $)_{4}\left[\mathrm{Ti}_{4} \mathrm{~F}_{20}\right]$ structures, the $\left[\mathrm{Ti}_{4} \mathrm{~F}_{20}\right]^{4-}$ anions are hydrogen-bonded to 12 and $14 \mathrm{ImH}^{+}$cations, respectively. The hydrogen bonds link the $\mathrm{ImH}^{+}$cations and tetrameric $\left[\mathrm{Ti}_{4} \mathrm{~F}_{20}\right]^{4-}$ anions into three-dimensional networks.

\subsubsection{Fluoridotitanates(IV) with pentameric and octameric complex anions}

The pentameric complex anion $\left[\mathrm{Ti}_{5} \mathrm{~F}_{23}\right]^{3-}$ is found in $(\operatorname{ImH})_{3}\left[\mathrm{Ti}_{5} \mathrm{~F}_{23}\right]$ [41] and comprises five $\mathrm{TiF}_{6}$ octahedral groups of unique geometries. All titanium atoms in $(\operatorname{ImH})_{3}\left[\mathrm{Ti}_{5} \mathrm{~F}_{23}\right]$ are 
crystallographically independent. Four of the $\mathrm{TiF}_{6}$ octahedra share two cis-vertices with adjacent $\mathrm{TiF}_{6}$ octahedra, thus forming a tetrameric unit, whose structure is identical to that of the complex $\left[\mathrm{Ti}_{4} \mathrm{~F}_{20}\right]^{4-}$ anion in $(\mathrm{ImH})_{4}\left[\mathrm{Ti}_{4} \mathrm{~F}_{20}\right]$ [41]. The fifth $\mathrm{TiF}_{6}$ octahedron shares three vertices with three of the $\mathrm{TiF}_{6}$ octahedra of the tetrameric unit. Four $\mathrm{TiF}_{6}$ octahedra in $\mathrm{Ti}_{5} \mathrm{~F}_{23}$ contain three bridging and three terminal fluorine atoms. The $\mathrm{Ti}$ atom of the fifth $\mathrm{TiF}_{6}$ octahedron is coordinated with two cis-bridging and four terminal fluorine atoms. The Ti- $\mathrm{F}_{\text {terminal }}$ and $\mathrm{Ti}-\mathrm{F}_{\text {bridging }}$ bond lengths are in the ranges 1.757(3)-1.848(3) and 1.942(2)-2.014(2) $\AA$, respectively. Hydrogen $\mathrm{N}-\mathrm{H} \cdots \mathrm{F}(\mathrm{N} \cdots \mathrm{F}$

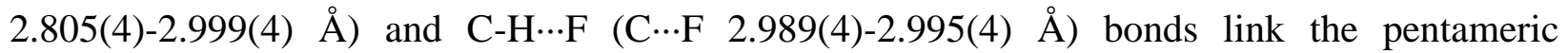
$\left[\mathrm{Ti}_{5} \mathrm{~F}_{23}\right]^{3-}$ anions and $\mathrm{ImH}^{+}$cations into a three-dimensional network.

The crystal structures of triclinic isostructural complexes $\mathrm{K}_{4}\left[\mathrm{Ti}_{8} \mathrm{~F}_{36}\right] \cdot 8 \mathrm{HF}$ and $\mathrm{Rb}_{4}\left[\mathrm{Ti}_{8} \mathrm{~F}_{36}\right] \cdot 6 \mathrm{HF}$ [71] consist of alkali metal cations, HF molecules, and $\left[\mathrm{Ti}_{8} \mathrm{~F}_{36}\right]^{4-}$ anions, built up from eight $\mathrm{TiF}_{6}$ octahedra with the titanium atoms located at the vertices of a regular cube. Each of $\mathrm{TiF}_{6}$ octahedra shares three fluorine atoms with three adjacent $\mathrm{TiF}_{6}$ octahedra. The Ti$\mathrm{F}_{\text {terminal }}$ and Ti- $\mathrm{F}_{\text {bridging }}$ bond lengths (Table 1) are in agreement with those in the structures of fluoridotitanates(IV) with tetrameric and pentameric anions [68, 41]. The coordination number of the $\mathrm{K}^{+}$or $\mathrm{Rb}^{+}$ions is nine. The $\mathrm{K} \cdots \mathrm{F}$ and $\mathrm{Rb} \cdots \mathrm{F}$ bond lengths are in the ranges 2.659(3)-

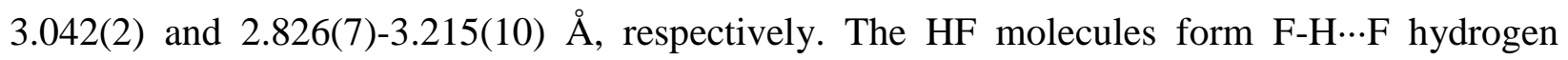
bonds with the fluorine atoms of the $\left[\mathrm{Ti}_{8} \mathrm{~F}_{36}\right]^{4-}$ anions with distances ranging from 2.53(2) to 2.58(2) $\AA$. In the $\mathrm{K}_{4}\left[\mathrm{Ti}_{8} \mathrm{~F}_{36}\right] \cdot 8 \mathrm{HF}$ and $\mathrm{Rb}_{4}\left[\mathrm{Ti}_{8} \mathrm{~F}_{36}\right] \cdot 6 \mathrm{HF}$ structures, each $\left[\mathrm{Ti}_{8} \mathrm{~F}_{36}\right]^{4-}$ anion is surrounded by twelve other anions, which are separated by K-HF (Rb-HF) pseudo-chains.

\subsection{Polymeric structures}

Polymeric fluoride complexes of Ti(IV) are represented by one-dimensional chain, double chains, layer and column crystal structures.

\subsubsection{One-dimensional chain structures}

Infinite chain $\left(\mathrm{TiF}_{5}\right)_{\infty}{ }^{-}$anions formed through linking octahedral $\mathrm{TiF}_{6}$ groups by cis-bridging $\mathrm{F}$ atoms form the $\left(\mathrm{H}_{3} \mathrm{O}\right) \mathrm{TiF}_{5}[72]$ and $\left(\mathrm{NH}_{4}\right) \mathrm{TiF}_{5}$ [73] crystal structures. In the $\left(\mathrm{H}_{3} \mathrm{O}\right) \mathrm{TiF}_{5}$ structure [72], polymeric chains formed by crystallographically independent $\mathrm{TiF}_{6}$ groups 
extended along the unit cell $b$ axis. The bridging Ti-F bonds are somewhat longer than the terminal Ti-F bonds. The $\mathrm{H}_{3} \mathrm{O}^{+}$cations hydrogen bond to three $\mathrm{F}$ atoms belonging to different chains. The $\mathrm{H}$ atoms in the structure were not determined. However, the short $\mathrm{O} \cdots \mathrm{F}$ distances (2.511(6)-2.558(5) ̊) are in the normal range observed for O-H...F hydrogen bonding.

Fig. 6 here

The asymmetric unit of the polymeric chain structure of $\left(\mathrm{NH}_{4}\right) \mathrm{TiF}_{5}$ [73] contains four sixcoordinated by fluorine atoms that are crystallographically independent. As in the structure of $\left(\mathrm{H}_{3} \mathrm{O}\right) \mathrm{TiF}_{5}$, the $\mathrm{TiF}_{6}$ groups of $\left(\mathrm{NH}_{4}\right) \mathrm{TiF}_{5}$ octahedral are linked by cis-bridging $\mathrm{F}$ atoms into infinite zigzag chains directed along the [101] axis (Fig. 6). The lengths of terminal and bridging Ti-F bonds in the four independent $\mathrm{TiF}_{6}$ groups of polymeric chains are in the ranges 1.762(2)1.849(2) and 1.972(2)-1.997(2) $\AA$, respectively (Table 1). The $\mathrm{NH}_{4}{ }^{+}$cations link the chains into a three-dimensional bonding network through $\mathrm{N}-\mathrm{H} \cdots \mathrm{F}$ hydrogen bonds (N...F av. 2.85-2.98 $\AA$ ).

\subsubsection{Double chain structures}

In contrast to $\left(\mathrm{H}_{3} \mathrm{O}\right) \mathrm{TiF}_{5}$ [72] and $\left(\mathrm{NH}_{4}\right) \mathrm{TiF}_{5}$ [73], which both have an one-dimensional chain structure, the fluoridotitanates(IV) $\left(\mathrm{H}_{3} \mathrm{O}\right) \mathrm{Ti}_{2} \mathrm{~F}_{9}, \mathrm{CsTi}_{2} \mathrm{~F}_{9},[68]$ and $(\mathrm{ImH})\left[\mathrm{Ti}_{2} \mathrm{~F}_{9}\right]$ [41] have a double chain structure. The compound $(\mathrm{ImH})\left[\mathrm{Ti}_{2} \mathrm{~F}_{9}\right]$ crystallizes in two modifications. The hightemperature $\beta$-phase $(298 \mathrm{~K})$ is orthorhombic, while the low-temperature $\alpha$-phase $(200 \mathrm{~K})$ is monoclinic. The structures of the four compounds comprise monocharged cations and $\left[\mathrm{Ti}_{2} \mathrm{~F}_{9}\right]^{-}$ complex anions, which have an infinite double chain structure. In all four compounds, the Tiatoms octahedrally surrounded each by six F-atoms. The $\mathrm{TiF}_{6}$ octahedra share cis-vertices to form infinite dimeric zigzag-like double chain $\left[\mathrm{Ti}_{2} \mathrm{~F}_{9}\right]_{\mathrm{n}}{ }^{-}$anions, in which each $\mathrm{TiF}_{6}$ octahedron shares vertices with three other $\mathrm{TiF}_{6}$ units. The titanium atoms are coordinated with three bridging (two within the chain and one between two polymeric chains) and three terminal fluorine atoms.

In $\beta$ - $(\operatorname{ImH})\left[\mathrm{Ti}_{2} \mathrm{~F}_{9}\right]$, the nearest-neighbor pairs of $\mathrm{TiF}_{6}$ octahedra belonging to different chains

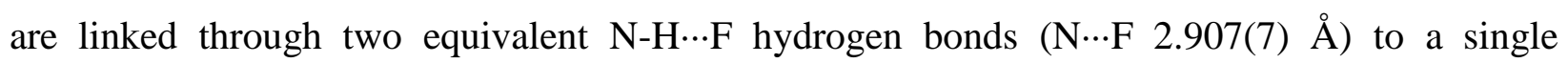
bridging $\mathrm{ImH}^{+}$cation. In the $\alpha$-phase, the nearest-neighbor pairs of $\mathrm{TiF}_{6}$ octahedra are linked by 


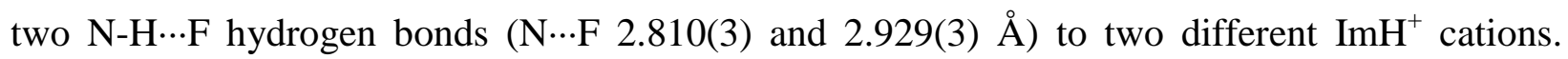
Hydrogen bonds and ionic strength combine the cations and the double chain anions into a threedimensional network.

\subsubsection{Layered structure}

The compound $\mathrm{CsTi}_{8} \mathrm{~F}_{33}$ was obtained serendipitously as a by-product of $\mathrm{TiF}_{4}$ synthesis. The structure of $\mathrm{CsTi}_{8} \mathrm{~F}_{33}$ [74] contains four crystallographically independent Ti atoms, each octahedrally surrounded by $\mathrm{F}$ atoms. The $\mathrm{Ti}(2) \mathrm{F}_{6}$ and $\mathrm{Ti}(3) \mathrm{F}_{6}$ octahedra are linked through cis-Fatoms of one of the triple faces to three octahedra of another type, which results in chair-like cycles built up by six octahedra, which are linked into corrugated layers parallel to (001). The $\operatorname{Ti}(1) \mathrm{F}_{6}$ and $\mathrm{Ti}(4) \mathrm{F}_{6}$ octahedra are located above and below each layer. In its turn, each $\mathrm{Ti}(1) \mathrm{F}_{6}$ and $\mathrm{Ti}(4) \mathrm{F}_{6}$ octahedron is linked through cis-F-atoms of one of the faces with $\mathrm{Ti}(2) \mathrm{F}_{6}$ and $\mathrm{Ti}(3) \mathrm{F}_{6}$ octahedra, respectively. As a result, layer packs, in which each octahedron is linked to a crystallographically different one, are formed from vertex-linked octahedra. The Cs atoms each surrounded by $12 \mathrm{~F}$ atoms of different $\mathrm{Ti}(1) \mathrm{F}_{6}$ octahedra form cuboctahedral coordination polyhedra typical for this atom. The 2D layers are linked through $\mathrm{Cs}$ atoms into a threedimensional structure.

\subsubsection{Column structure}

The crystal structure of $\left(\mathrm{O}_{2}\right)_{2} \mathrm{Ti}_{7} \mathrm{~F}_{30}$ [75] has some similarity to that of $\mathrm{TiF}_{4}$ [76]. Just like $\mathrm{TiF}_{4}$, the $\left(\mathrm{O}_{2}\right)_{2} \mathrm{Ti}_{7} \mathrm{~F}_{30}$ structure contains isolated columns built up of vertex-linked $\mathrm{TiF}_{6}$ octahedra directed along the [001] planes. The crystal structure of $\left(\mathrm{O}_{2}\right)_{2} \mathrm{Ti}_{7} \mathrm{~F}_{30}$ contains two different types

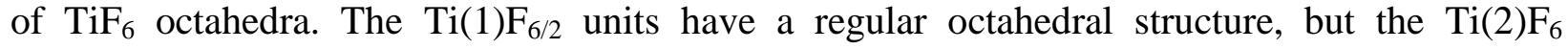
octahedra are significantly distorted, with the $\mathrm{Ti}(2)$ atom displaced significantly from the center of the octahedron. The $\mathrm{Ti}(1) \mathrm{F}_{6 / 2}$ octahedra are linked through bridging $\mathrm{F}(1)$ atoms to six $\mathrm{Ti}(2) \mathrm{F}_{6}$ octahedra with formation of a six-membered $\left(\mathrm{Ti}_{6} \mathrm{~F}_{30}\right)$ cycle with $\mathrm{Ti}(1) \mathrm{F}_{6 / 2}$ in the center. In their turn, $\mathrm{Ti}(2) \mathrm{F}_{6}$ octahedra are linked through bridging $\mathrm{F}(2)$ atoms to octahedra of the same type from adjacent cycles with formation of polymeric columns. In $\left(\mathrm{O}_{2}\right)_{2} \mathrm{Ti}_{7} \mathrm{~F}_{30}$, the isolated columns are linked to loosely disordered $\left(\mathrm{O}_{2}\right)^{2+}$ cations.

\section{Structures of oxo- and hydroxyfluoride complexes of titanium(IV)}


The present section is devoted to the crystal structures of anionic oxo- and hydroxyfluoride complexes of titanium(IV) with Ti atom in an octahedral environment.

\subsection{Structures of oxofluoride complexes}

\subsubsection{Monomeric structures}

Substitution of one, two, or three fluorine atoms by oxygen atoms in $\mathrm{A}_{2}\left[\mathrm{MeF}_{6}\right]$ complexes results in significant changes in the crystal structure. According to the X-ray diffraction studies, a large group of alkali metal oxofluoridometallates, $\mathrm{A}_{2} \mathrm{~A}^{\prime} \quad \mathrm{M}^{\mathrm{IV}} \mathrm{OF}_{5}, \mathrm{~A}_{2} \mathrm{~A}^{\prime} \quad \mathrm{M}^{\mathrm{V}} \mathrm{O}_{2} \mathrm{~F}_{4}$, and $\mathrm{A}_{2} \mathrm{~A}^{\prime} \mathrm{M}^{\mathrm{VI}} \mathrm{O}_{3} \mathrm{~F}_{3}$, where $\mathrm{A}$ is larger than $\mathrm{A}^{\prime}, \mathrm{M}^{\mathrm{IV}}=\mathrm{Ti}, \mathrm{V} ; \mathrm{M}^{\mathrm{V}}=\mathrm{V}, \mathrm{Nb}$, and $\mathrm{M}^{\mathrm{VI}}=\mathrm{Mo}, \mathrm{W}$, crystallize in the cubic symmetry, $(F m \overline{3} m)$, and are assigned to the structural type of elpasolite [77]. In the $\mathrm{A}_{2} \mathrm{~A}^{\prime} \mathrm{TiOF}_{5}$ series, only the compounds $\mathrm{Na}_{2} \mathrm{LiTiOF}_{5}$ and $\mathrm{Cs}_{2} \mathrm{NaTiOF}_{5}$ are not cubic. The crystal structure of $\mathrm{K}_{2} \mathrm{NaTiOF}_{5}$ was determined from the X-ray powder data based upon the positions of the elpasolite structural type [77]. The calculations were performed on 18 reflections using the least-squares method, polarization and temperature factors. The structure was refined to $\mathrm{R}=0.0671$. The assignment of the $\mathrm{K}_{2} \mathrm{NaTiOF}_{5}$ structure (cubic symmetry, $F m \overline{3} m$ ) to the elpasolite structural type was confirmed. The calculated average Ti- $(\mathrm{O}, \mathrm{F})$ distance in the structure is equal to $1.918 \AA$.

Using single-crystal X-ray diffraction, the structure of $\mathrm{Rb}_{2} \mathrm{KTiOF}_{5}$ was determined at 297 and $218 \mathrm{~K}$ [78]. The compound crystallizes in the cubic symmetry, $F m \overline{3} m$ space group, and is assigned to the elpasolite structural type. The unit cell parameter of $\mathrm{Rb}_{2} \mathrm{KTiOF}_{5}$ at $297 \mathrm{~K}$ found from the single crystal $(8.9002(1) \AA)$ is slightly different from that $(8.874 \AA$ ) obtained by X-ray powder investigation [77]. Disordered $\mathrm{F}$ and $\mathrm{O}$ atoms in the room-temperature $\mathrm{Rb}_{2} \mathrm{KTiOF}_{5}$ structure were located in the statistical "mixed" $24 \mathrm{e}+96 \mathrm{j}$ position of the $F m \overline{3} m$ unit cell. The unique Ti-X(1) and $\mathrm{Ti}-\mathrm{X}(2)(\mathrm{X}=\mathrm{O}, \mathrm{F})$ bond lengths in the room-temperature $\mathrm{Rb}_{2} \mathrm{KTiOF}_{5}$ structure are 1.914(2) and 1.872(3) $\AA$, respectively. The Ti atoms in $\mathrm{Rb}_{2} \mathrm{KTiOF}_{5}$ (lowtemperature) are shifted enabling the localization of the $\mathrm{O}$ and $\mathrm{F}$ atoms in a separate orientations of the $\mathrm{TiOF}_{5}$ octahedra.

The crystal structure of $\left(\mathrm{NH}_{4}\right)_{3} \mathrm{TiOF}_{5}$ was studied in [78], and investigated in detail and refined in [79]. Cubic crystals of $\left(\mathrm{NH}_{4}\right)_{3} \mathrm{TiOF}_{5}(\mathrm{Fm} \overline{3} \mathrm{~m})$ belong to the family of elpasolites. The fluorine and oxygen atoms in $\left[\mathrm{TiOF}_{5}\right]^{3-}$ are distributed randomly. Refinement of the 
$\left(\mathrm{NH}_{4}\right)_{3} \mathrm{TiOF}_{5}$ structure was performed by localizing the $(\mathrm{F}, \mathrm{O})$ atoms in four acceptable positions of the cubic $F m \overline{3} m$ system [79]. It was established that the most acceptable solution was the distribution of $(\mathrm{F}, \mathrm{O})$ atoms statistically in two different crystallographic sites. In this case, the lowest R-value is obtained. Attempts to determine the $\left(\mathrm{NH}_{4}\right)_{3} \mathrm{TiOF}_{5}$ structure at $173 \mathrm{~K}$ were unsuccessful, since the crystals changed into polydomain states below the phase transition. The nature of dynamic orientation disorder in the $\left(\mathrm{NH}_{4}\right)_{3} \mathrm{TiOF}_{5}$ and $\mathrm{Rb}_{2} \mathrm{KTiOF}_{5}$ crystal structures has been discussed in detail [78].

Isolated complex $\left[\mathrm{TiF}_{5}\left(\mathrm{H}_{2} \mathrm{O}\right)\right]^{-}$anions are present in $\left(\mathrm{C}_{7} \mathrm{H}_{9} \mathrm{NH}\right)\left[\mathrm{TiF}_{5}\left(\mathrm{H}_{2} \mathrm{O}\right)\right]$ [38] and $\left(\mathrm{C}_{4} \mathrm{H}_{10} \mathrm{~N}_{2} \mathrm{H}_{2}\right)\left[\mathrm{TiF}_{5}\left(\mathrm{H}_{2} \mathrm{O}\right)\right]_{2}$ [80]. Both compounds have the same crystal structure composed of protonated cations $\left(\mathrm{C}_{7} \mathrm{H}_{9} \mathrm{NH}^{+}=2\right.$,6-lutidinium; $\mathrm{C}_{4} \mathrm{H}_{10} \mathrm{~N}_{2} \mathrm{H}_{2}{ }^{2+}=$ piperazinium $)$ and octahedral $\left[\mathrm{TiF}_{5}\left(\mathrm{H}_{2} \mathrm{O}\right)\right]^{-}$complex anions linked through hydrogen bonds $\mathrm{O}-\mathrm{H} \cdots \mathrm{F}$ and $\mathrm{N}-\mathrm{H} \cdots \mathrm{F}$ (Fig. 7).

Fig. 7 here

The Ti-F bond lengths in $\left[\mathrm{TiF}_{5}\left(\mathrm{H}_{2} \mathrm{O}\right)\right]^{-}$anions are very similar ranging from $1.786(1)$ to $1.859(1) \quad \AA$ in $\left(\mathrm{C}_{7} \mathrm{H}_{9} \mathrm{NH}\right)\left[\mathrm{TiF}_{5}\left(\mathrm{H}_{2} \mathrm{O}\right)\right]$ and from $1.799(2)$ to $1.855(2) \AA$ in $\left(\mathrm{C}_{4} \mathrm{H}_{10} \mathrm{~N}_{2} \mathrm{H}_{2}\right)\left[\mathrm{TiF}_{5}\left(\mathrm{H}_{2} \mathrm{O}\right)\right]_{2}$. There are some minor differences in the $\mathrm{Ti}-\mathrm{H}_{2} \mathrm{O}$ bond lengths, which are 2.1151(17) and 2.084(3) $\AA$, respectively. According to the trans-effect [134], the fluorine atom in trans-position to the coordinated $\mathrm{H}_{2} \mathrm{O}$ molecule forms the shortest Ti-F bond in octahedron (Table 1).

Similarity of crystal structures of $\left(\mathrm{C}_{7} \mathrm{H}_{9} \mathrm{NH}\right)\left[\mathrm{TiF}_{5}\left(\mathrm{H}_{2} \mathrm{O}\right)\right]$ and $\left(\mathrm{C}_{4} \mathrm{H}_{10} \mathrm{~N}_{2} \mathrm{H}_{2}\right)\left[\mathrm{TiF}_{5}\left(\mathrm{H}_{2} \mathrm{O}\right)\right]_{2}$ is also evident in formation of the same system of $\mathrm{O}-\mathrm{H} \cdots \mathrm{F}$ and $\mathrm{N}-\mathrm{H} \cdots \mathrm{F}$ hydrogen bonds linking cations and anions into a three-dimensional network. In the $\left(\mathrm{C}_{7} \mathrm{H}_{9} \mathrm{NH}\right)\left[\mathrm{TiF}_{5}\left(\mathrm{H}_{2} \mathrm{O}\right)\right]$ and $\left(\mathrm{C}_{4} \mathrm{H}_{10} \mathrm{~N}_{2} \mathrm{H}_{2}\right)\left[\mathrm{TiF}_{5}\left(\mathrm{H}_{2} \mathrm{O}\right)\right]_{2}$ structures, the $\mathrm{TiF}_{5}\left(\mathrm{H}_{2} \mathrm{O}\right)$ octahedra form parallel linear chains. The $\mathrm{O}$ atoms of the $\mathrm{H}_{2} \mathrm{O}$ molecule of each chain octahedron form two $\mathrm{O}-\mathrm{H} \cdots \mathrm{F}$ hydrogen bonds with the $\mathrm{F}$ atoms of two interfacing octahedra of the adjacent chain with formation of a double chain (band). The lengths of $\mathrm{O}-\mathrm{H} \cdots \mathrm{F}$ hydrogen bonds are about the same in the structures of both compounds and equal to 2.604(2), 2.628(2) and 2.608(4), 2.638(4) $\AA$, respectively. The double chains (bands) are linked to each other with formation of layers by F...F contacts with distances of 2.727 and $2.844 \AA$ that are close to the sum of van der Waals radii of fluorine atoms. The 
layers in the structures of both compounds are linked into a three-dimensional network through $\mathrm{N}-\mathrm{H} \cdots \mathrm{F}$ hydrogen bonds (2.723(4)-2.863(2) Å).

\subsubsection{Dimeric structures}

Dimeric $\left[\mathrm{Ti}_{2} \mathrm{~F}_{9}\left(\mathrm{H}_{2} \mathrm{O}\right)_{2}\right]^{-}$complex anions composed of distorted octahedral $\mathrm{TiF}_{5}\left(\mathrm{H}_{2} \mathrm{O}\right)$ groups linked by the bridging $\mathrm{F}$ atom are contained in the crystal structure of $\left(\mathrm{NMe}_{4}\right)_{4}\left[\mathrm{Ti}(1)_{2} \mathrm{~F}_{11}\right]\left[\mathrm{Ti}(2)_{2} \mathrm{~F}_{9}\left(\mathrm{H}_{2} \mathrm{O}\right)_{2}\right]$ in addition to dimeric $\left[\mathrm{Ti}_{2} \mathrm{~F}_{11}\right]^{3-}$ anions [64]. The presence of the coordinated $\mathrm{H}_{2} \mathrm{O}$ molecule and the bridging Ti-F-Ti bond yields a significant variation in Ti$\mathrm{F}_{\text {terminal }}$ bond lengths in the $\mathrm{TiF}_{5}\left(\mathrm{H}_{2} \mathrm{O}\right)$ group. The Ti- $\mathrm{OH}_{2}$ bond length is 2.1252(16) $\AA$, which is similar to bond lengths found for isolated octahedral $\left[\mathrm{TiF}_{5}\left(\mathrm{H}_{2} \mathrm{O}\right)\right]^{-}$anions $(2.1151(17)$ and 2.084(3) А) [38, 80] .

The coordinated $\mathrm{H}_{2} \mathrm{O}$ molecules of the dimeric $\left[\mathrm{Ti}_{2} \mathrm{~F}_{9}\left(\mathrm{H}_{2} \mathrm{O}\right)_{2}\right]^{-}$anion form rather strong O$\mathrm{H} \cdots \mathrm{F}$ hydrogen bonds with the $\left[\mathrm{Ti}_{2} \mathrm{~F}_{11}\right]^{3-}$ dimers, at distances of $2.549(4)$ and 2.593(4) $\AA$. Through these hydrogen bonds, dimeric complex anions $\left[\mathrm{Ti}_{2} \mathrm{~F}_{11}\right]^{3-}$ and $\left[\mathrm{Ti}_{2} \mathrm{~F}_{9}\left(\mathrm{H}_{2} \mathrm{O}\right)_{2}\right]^{-}$form virtually straight polymer chains. The $\mathrm{NMe}_{4}{ }^{+}$cations are located between the chains, forming a branched system of $\mathrm{C}-\mathrm{H} \cdots \mathrm{F}$ hydrogen bonds and a three-dimensional structure.

The crystal structure of $\left(\mathrm{C}_{4} \mathrm{H}_{10} \mathrm{~N}_{2} \mathrm{H}_{2}\right)_{2}\left[\mathrm{Ti}_{2} \mathrm{~F}_{10} \mathrm{O}\right] \cdot 2 \mathrm{H}_{2} \mathrm{O}$ [81] is composed of dimeric $\left[\mathrm{Ti}_{2} \mathrm{~F}_{10} \mathrm{O}\right]^{4-}$ complex anions built up by the vertex-shared oxygen atom of $\mathrm{TiF}_{5} \mathrm{O}$ octahedral groups, diprotonated piperazinium cations, and lattice water molecules (Fig. 8). The structure is similar to that of $\left(\mathrm{C}_{5} \mathrm{H}_{5} \mathrm{NH}\right)_{2}\left(\mathrm{H}_{3} \mathrm{O}\right)\left[\mathrm{Ti}_{2} \mathrm{~F}_{11}\right] \cdot \mathrm{H}_{2} \mathrm{O}$ [63], in which dimeric complex anions are formed by octahedral $\mathrm{TiF}_{6}$ groups linked by common vertex.

Fig. 8 here

Unlike the $\left[\mathrm{Ti}_{2} \mathrm{~F}_{11}\right]^{3-}$ anion, in which octahedral $\mathrm{TiF}_{6}$ groups are equivalent and linked into a dimer by the bridging $\mathrm{F}$ atom, the $\mathrm{TiF}_{5} \mathrm{O}$ groups in the dimeric $\left[\mathrm{Ti}_{2} \mathrm{~F}_{10} \mathrm{O}\right]^{4-}$ anion are crystallographically nonequivalent and linked into a dimer by the bridging oxygen atom. In the $\mathrm{Ti}_{2} \mathrm{~F}_{10} \mathrm{O}$ dimer, the two Ti-O bond lengths are 1.803(2) and 1.812(2) $\AA$; these values are somewhat smaller than the corresponding Ti-F bond lengths (1.844(2) to 1.967(2) A). Such a relation is unusual for dimeric compounds with common bridging bond. In the $\mathrm{Ti}_{2} \mathrm{~F}_{10} \mathrm{O}$ dimer, 
the Ti-F bonds located trans to the bridging $\mathrm{O}$ atoms are longer (1.964(2) and 1.967(2) $\AA$ ) as compared to the other Ti-F bond lengths (1.844(2) to 1.892(2) $\AA$ ). In contrast, in the $\mathrm{Ti}_{2} \mathrm{~F}_{11}$ dimer the Ti-F distance trans to the bridging $\mathrm{F}$ atom is shorter $(1.776(2) \AA)$ than that of other $\mathrm{F}$ atoms (1.796(2)-1.880(2) $\AA$ ). The $\mathrm{NH}_{2}$ groups of $\mathrm{C}_{4} \mathrm{H}_{10} \mathrm{~N}_{2} \mathrm{H}_{2}{ }^{2+}$ cations form with the $\mathrm{F}$ atoms of dimeric anions an extended network of $\mathrm{N}-\mathrm{H} \cdots \mathrm{F}$ hydrogen bonds. The $\mathrm{N} \cdots \mathrm{F}$ distances range from $2.633(3)$ to $2.862(3) \AA$. Through hydrogen bonds and van der Waals interactions, the structural units are linked into a three-dimensional network.

The dimeric crystal structure of tris(tetramethyltetraselenafulvalene) $\mu_{2}$-oxalatobis[tetrafluoridotitanate(IV)] $\quad\left(\mathrm{C}_{10} \mathrm{H}_{12} \mathrm{Se}_{4}\right)_{3}\left[\mathrm{Ti}_{2} \mathrm{~F}_{8}\left(\mathrm{C}_{2} \mathrm{O}_{4}\right)\right] \quad\left((\mathrm{TMTSF})_{3}\left[\mathrm{Ti}_{2} \mathrm{~F}_{8}\left(\mathrm{C}_{2} \mathrm{O}_{4}\right)\right]\right) \quad$ [82] is isotypical to that of $\left(\mathrm{C}_{10} \mathrm{H}_{12} \mathrm{~S}_{4}\right)_{3}\left[\mathrm{Ti}_{2} \mathrm{~F}_{10}\right]\left((\mathrm{TMTTF})_{3} \mathrm{Ti}_{2} \mathrm{~F}_{10}\right)$ [65]. Its differs from the latter by the fact that $\left(\mathrm{C}_{10} \mathrm{H}_{12} \mathrm{Se}_{4}\right)$ cations are selenium derivatives, while the dimeric complex anion $\left[\mathrm{Ti}_{2} \mathrm{~F}_{8}\left(\mathrm{C}_{2} \mathrm{O}_{4}\right)\right]^{2-}$ contains a bridging oxalate instead of edge-shared fluoride group (Fig. 9).

Fig. 9 here

The Ti- $\mathrm{F}_{\text {terminal }}$ bond lengths in the dimeric $\left[\mathrm{Ti}_{2} \mathrm{~F}_{8}\left(\mathrm{C}_{2} \mathrm{O}_{4}\right)\right]^{2-}$ anion are identical to the Ti$\mathrm{F}_{\text {terminal }}$ bond lengths in the $\left[\mathrm{Ti}_{2} \mathrm{~F}_{10}\right]^{2-}$ anion of the $\left(\mathrm{C}_{10} \mathrm{H}_{12} \mathrm{~S}_{4}\right)_{3}\left[\mathrm{Ti}_{2} \mathrm{~F}_{10}\right]$ structure [65]. The bridging Ti-O bond lengths $(2.112(6)$ and 2.133(6) $\AA$ ) have the values characteristic for Ti-O bonds in the structures of oxofluoride complexes of titanium(IV). As in the structure of (TMTTF $)_{3}\left[\mathrm{Ti}_{2} \mathrm{~F}_{10}\right]$, the TMTSF molecules in (TMTSF $)_{3}\left[\mathrm{Ti}_{2} \mathrm{~F}_{8}\left(\mathrm{C}_{2} \mathrm{O}_{4}\right)\right]$ form a trimerized structure, and the triads extend along the $b$ axis. According to [82], in the trimeric group $\left(\mathrm{C}_{10} \mathrm{H}_{12} \mathrm{Se}_{4}\right)_{3}$ two of three $\mathrm{C}_{10} \mathrm{H}_{12} \mathrm{Se}_{4}$ are +1 , while the third molecule is neutral.

\subsubsection{Chain structures}

The structure of $\left(\mathrm{C}_{4} \mathrm{H}_{12} \mathrm{~N}_{2} \mathrm{H}_{2}\right)\left[\mathrm{TiF}_{4} \mathrm{O}\right]$ is composed of one-dimensional [ $\mathrm{TiF}_{4} \mathrm{O}_{\infty}{ }_{\infty}^{2-}$ chains composed of octahedral $\mathrm{TiF}_{4} \mathrm{O}_{2}$ groups linked through trans-located bridging oxygen atoms and diprotonated 1,4-diaminobutanium cations (Fig. 10) [83]. Unlike the dimeric crystal structure of $\left(\mathrm{C}_{4} \mathrm{H}_{10} \mathrm{~N}_{2} \mathrm{H}_{2}\right)_{2}\left[\mathrm{Ti}_{2} \mathrm{~F}_{10} \mathrm{O}\right] \cdot 2 \mathrm{H}_{2} \mathrm{O}$ [81], in which the Ti-F bond lengths are somewhat longer than that of the bridging Ti-O bond, the Ti-F distances are significantly shorter that the Ti-O ones. The polymeric chains are parallel to the $c$-axis and are held together in polymeric layers via $\mathrm{N}-\mathrm{H} \cdots \mathrm{F}$ 
hydrogen bonds $\left(2.735(3)\right.$ and $2.780(3) \AA$ ) formed by $\mathrm{NH}_{3}{ }^{+}$groups of 1,4-diaminobutanium cations with $\mathrm{F}$ atoms of adjacent chains.

Fig. 10 here

The crystal structure of $\left(\mathrm{enH}_{2}\right)\left(\mathrm{TiF}_{4} \mathrm{O}\right)$ [84] is similar to that of $\left(\mathrm{C}_{4} \mathrm{H}_{12} \mathrm{~N}_{2} \mathrm{H}_{2}\right)$ [TiF $4 \mathrm{O}$ ] [83]. It is built up of infinite $\left(\mathrm{TiF}_{4} \mathrm{O}\right)_{\infty}{ }^{2-}$ chains composed of trans- $\mathrm{TiF}_{4} \mathrm{O}_{2}$ octahedral groups linked through the $\mathrm{O}$ atoms and diprotonated ethylenediammonium $\mathrm{enH}_{2}{ }^{2+}$ cations (Fig. 11). Unlike $\left(\mathrm{C}_{4} \mathrm{H}_{12} \mathrm{~N}_{2} \mathrm{H}_{2}\right)\left[\mathrm{TiF}_{4} \mathrm{O}\right]$ that contains just one type of infinite chain, the structure of $\left(\mathrm{enH}_{2}\right)\left(\mathrm{TiF}_{4} \mathrm{O}\right)$ contains two types of infinite chains composed of two crystallographically inequivalent octahedral $\mathrm{TiF}_{4} \mathrm{O}_{2}$. In the $\mathrm{Ti}(1) \mathrm{F}_{4} \mathrm{O}_{2}$ group, the unique Ti-F and Ti-O bond lengths are 1.894(2) and 2.010(1) $\AA$, respectively. Similar values (1.919(3) $\AA$ ) characterize the Ti-F bond lengths in $\mathrm{Ti}(2) \mathrm{F}_{4} \mathrm{O}_{2}$ groups. Unlike $\mathrm{Ti}(1) \mathrm{F}_{4} \mathrm{O}_{2}$, one of the Ti-O distances in the $\mathrm{Ti}(2) \mathrm{F}_{4} \mathrm{O}_{2}$ groups is short (1.690(5) $\AA$ ), which is characteristic for the titanyl bond, whereas the second bridging Ti-O distance is significantly elongated (2.330(5) $\AA$ ). The Ti(2) atom is displaced from the octahedral center in the direction of the shortened Ti-O bond.

Fig. 11 here

The infinite chains making up the $\mathrm{Ti}(1) \mathrm{F}_{4} \mathrm{O}_{2}$ groups are similar to those in the structure of $\left(\mathrm{C}_{4} \mathrm{H}_{12} \mathrm{~N}_{2} \mathrm{H}_{2}\right)\left[\mathrm{TiF}_{4} \mathrm{O}\right]$ [83]. The $\left(\mathrm{Ti}(2) \mathrm{F}_{4} \mathrm{O}\right)_{\infty}{ }^{2-}$ chains are staggered. The torsion angle $\mathrm{Ti}(2)-\mathrm{F}(2)-$ $\mathrm{F}(2)-\mathrm{Ti}(2)$ between neighboring octahedra is $21.5^{\circ}$. The $\mathrm{F}$ atoms are involved in formation of $\mathrm{N}$ $\mathrm{H} \cdots \mathrm{F}$ hydrogen bonds with ethylenediammonium cations. The $\mathrm{N} \cdots \mathrm{F}$ values range from $2.69(1)$ to 2.79(1) ^.

\subsubsection{Layered structure}

The crystal structure of titanium(IV) oxofluoride compound $\left[\mathrm{N}\left(\mathrm{CH}_{2}\right)_{3}\right]_{2}\left(\mathrm{Ti}_{5} \mathrm{O}_{5} \mathrm{~F}_{12}\right)$ [85] was determined from powder X-ray data by combining the direct space method, Rietveld refinement, and density functional theory geometry optimization. The asymmetric unit of $\left[\mathrm{N}\left(\mathrm{CH}_{2}\right)_{3}\right]_{2}\left(\mathrm{Ti}_{5} \mathrm{O}_{5} \mathrm{~F}_{12}\right)$ contains two nonequivalent Ti atoms, each surrounded by four $\mathrm{F}$ and two 
$\mathrm{O}$ atoms forming significantly distorted $\mathrm{TiF}_{4} \mathrm{O}_{2}$ octahedra. $\mathrm{In} \operatorname{Ti}(1) \mathrm{F}_{4} \mathrm{O}_{2}$, the Ti-F bond lengths

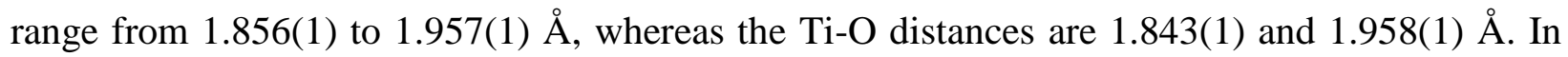
the $\mathrm{Ti}(2) \mathrm{F}_{4} \mathrm{O}_{2}$ octahedra, four Ti-F are identical (1.952(1) $\left.\mathrm{A}\right)$. One Ti-O distance is rather short (1.699(1) $\AA$ ), which is characteristic for the titanyl-ion, while the second Ti-O distance is significantly elongated (2.103(1) $⿱$ ) , which is caused by the trans-effect [134]. The two $\mathrm{TiF}_{4} \mathrm{O}_{2}$ groups are linked through bridging $\mathrm{F}$ atoms into alternating infinite inorganic $\left(\mathrm{Ti}_{5} \mathrm{O}_{5} \mathrm{~F}_{12}\right)_{\infty}$ layers separated by guanidinium cations. The $\left(\mathrm{Ti}_{5} \mathrm{O}_{5} \mathrm{~F}_{12}\right)_{\infty}$ layers can be also described from the association with the fluorine corners of two types of infinite $\left(\mathrm{TiF}_{4} \mathrm{O}\right)_{\infty}$ chains formed by cornersharing $\operatorname{Ti}(1) \mathrm{F}_{4} \mathrm{O}_{2}$ and $\mathrm{Ti}(2) \mathrm{F}_{4} \mathrm{O}_{2}$ groups through the trans, bridging oxygen atoms.

\subsection{Hydroxyfluoridotitanate(IV) structures}

Hybrid organic-inorganic hydroxyfluoridotitanates(IV) $\left(\mathrm{C}_{2} \mathrm{H}_{5} \mathrm{~N}_{5} \mathrm{H}\right)_{2}\left[\mathrm{TiF}_{4.9}(\mathrm{OH})_{1.1}\right]$, $\left(\mathrm{C}_{2} \mathrm{H}_{5} \mathrm{~N}_{5} \mathrm{H}_{2}\right)\left[\mathrm{TiF}_{4.8}(\mathrm{OH})_{1.2}\right]\left(\mathrm{C}_{2} \mathrm{H}_{5} \mathrm{~N}_{5}\right.$ - 3,5-diamino-1,2,4-triazole $)$, $\left(\mathrm{enH}_{2}\right)\left[\mathrm{TiF}_{4.3}(\mathrm{OH})_{1.7}\right]$, and $\left(\mathrm{dienH}_{2}\right)\left[\mathrm{Ti}(\mathrm{F}, \mathrm{OH})_{6}\right] \cdot 2 \mathrm{H}_{2} \mathrm{O}$ were synthesized and structurally investigated [86]. All compounds exhibit monomeric structures built up by isolated octahedral $\left[\mathrm{Ti}(\mathrm{F}, \mathrm{OH})_{6}\right]^{2-}$ anions and mono- or di-protonated amine cations. Within the $\left[\mathrm{Ti}(\mathrm{F}, \mathrm{OH})_{6}\right]^{2-}$ anion, the $\mathrm{F}$ and $\mathrm{OH}$ ligands are distributed randomly. The Ti- $(\mathrm{F}, \mathrm{OH})$ bond lengths in $\left[\mathrm{Ti}(\mathrm{F}, \mathrm{OH})_{6}\right]^{2-}$ vary in the range 1.816-1.893 $\AA$. The $\mathrm{NH}_{2}\left(\mathrm{NH}_{3}\right)$ groups of protonated cations interact with the $\mathrm{F}(\mathrm{OH})$ species via $\mathrm{N}-\mathrm{H} \cdots \mathrm{F}(\mathrm{OH})$ hydrogen bonds. The hydrogen bonds link the building units in a three-dimensional framework.

Hydroxyfluoridotitanates(IV) templated by tren cations $\left(\right.$ tren $\left.\mathrm{H}_{4}\right)\left[\mathrm{TiF}_{4.6}(\mathrm{OH})_{1.4}\right]_{2} \cdot 2.7 \mathrm{H}_{2} \mathrm{O}, \beta$ $\left(\operatorname{tren} \mathrm{H}_{3}\right)\left[\mathrm{TiF}_{4.5}(\mathrm{OH})_{1.5}\right](\mathrm{F})$, and $\alpha-\left(\operatorname{tren} \mathrm{H}_{3}\right)\left[\mathrm{TiF}_{4.7}(\mathrm{OH})_{1.3}\right](\mathrm{F})$ were also described [137].

\section{Structures of peroxofluoride complexes of titanium(IV)}

\subsection{Monomeric structures}

The compound $\left(\mathrm{NH}_{4}\right)_{3}\left[\mathrm{Ti}\left(\mathrm{O}_{2}\right) \mathrm{F}_{5}\right]$ was an object of a number of structural studies initiated to

determine the structural model of an isolated monomeric complex $\left[\operatorname{Ti}\left(\mathrm{O}_{2}\right) \mathrm{F}_{5}\right]^{3-}$ anion. The crystals of $\left(\mathrm{NH}_{4}\right)_{3}\left[\mathrm{Ti}\left(\mathrm{O}_{2}\right) \mathrm{F}_{5}\right]$ belong to the cubic symmetry $(F m \overline{3} m)$. Stomberg and Svensson 
[87] studied the crystal structure of $\left(\mathrm{NH}_{4}\right)_{3}\left[\mathrm{Ti}\left(\mathrm{O}_{2}\right) \mathrm{F}_{5}\right]$ by the integrated Weissenberg film method and proposed a cubic symmetry $(F m \overline{3} m)$. The authors suggested the pentagonal-bipyramidal model for the $\left[\mathrm{Ti}\left(\mathrm{O}_{2}\right) \mathrm{F}_{5}\right]^{3-}$ anion similar to that of the $\left[\mathrm{Nb}\left(\mathrm{O}_{2}\right) \mathrm{F}_{5}\right]^{2-}$ anion in $\mathrm{Na}_{2}\left[\mathrm{Nb}\left(\mathrm{O}_{2}\right) \mathrm{F}_{5}\right] \cdot \mathrm{H}_{2} \mathrm{O}$ [135].

The crystal structure of $\left(\mathrm{NH}_{4}\right)_{3}\left[\mathrm{Ti}\left(\mathrm{O}_{2}\right) \mathrm{F}_{5}\right]$ was studied for comparison to the cubic structures of $\left(\mathrm{NH}_{4}\right)_{3}\left[\mathrm{Nb}\left(\mathrm{O}_{2}\right)_{2} \mathrm{~F}_{4}\right]$ and $\left(\mathrm{NH}_{4}\right)_{3}\left[\mathrm{Ta}\left(\mathrm{O}_{2}\right)_{2} \mathrm{~F}_{4}\right](\mathrm{Fm} \overline{3} \mathrm{~m})$ [88]. The metal atoms in these structures have octahedral coordination. Two vertices in the coordination polyhedron occupy the center of the peroxo-bonds. The authors [88] assumed that $\left[\mathrm{Ti}\left(\mathrm{O}_{2}\right) \mathrm{F}_{5}\right]^{3-}$ anions in $\left(\mathrm{NH}_{4}\right)_{3}\left[\mathrm{Ti}\left(\mathrm{O}_{2}\right) \mathrm{F}_{5}\right]$ must also have octahedral coordination with the midpoint of the peroxo O-O bond occupying one of the vertices in the coordination polyhedron. The authors suggested that the coordination polyhedron of the $\mathrm{Ti}$ atom in $\left(\mathrm{NH}_{4}\right)_{3}\left[\mathrm{Ti}\left(\mathrm{O}_{2}\right) \mathrm{F}_{5}\right]$ can be also described as a pentagonal bipyramid with a bidentate-coordinated peroxo-group.

The cubic crystal structure of $\left(\mathrm{NH}_{4}\right)_{3}\left[\mathrm{Ti}\left(\mathrm{O}_{2}\right) \mathrm{F}_{5}\right]$ [89] could be represented as containing disordered pentagonal-bipyramidal monomeric complex anions $\left[\mathrm{Ti}\left(\mathrm{O}_{2}\right) \mathrm{F}_{5}\right]^{3-}$ similar to the $\left[\mathrm{ZrF}_{7}\right]^{3-}$ anion in the structure of $\left(\mathrm{NH}_{4}\right)_{3}\left[\mathrm{ZrF}_{7}\right]$ [136], with a shortened O-O distance in one of the vertices. However, according to [89], the structure of the $\left[\mathrm{Ti}\left(\mathrm{O}_{2}\right) \mathrm{F}_{5}\right]^{3-}$ anion is better described as an octahedron in the structural type of elpasolite, in which the five $\mathrm{F}$ atoms and the $\mathrm{O}_{2}{ }^{2-}$ groups are statistically disordered over all of the octahedral sites. The disordered $\mathrm{NH}_{4}{ }^{+}$cations participate in formation of hydrogen bonds with both $\mathrm{F}$ atoms and $\mathrm{O}_{2}{ }^{2-}$ groups of the anions. The $\mathrm{N} \cdots \mathrm{F}$ and $\mathrm{N} \cdots \mathrm{O}$ bond lengths are 2.735(6), 3.292(1) and 2.809(4), 3.015(5) $\AA$, respectively. This disorder model enabled the authors to obtain what they believed to be a more reliable complex ion geometry [90]. Using that model and the experimental intensities for 118 reflections from [89], the crystal structure of $\left(\mathrm{NH}_{4}\right)_{3}\left[\mathrm{Ti}\left(\mathrm{O}_{2}\right) \mathrm{F}_{5}\right]$ was refined to $\mathrm{R}=0.019$ as compared to 0.042 of the original structure determination [90]. These atomic coordinates from the disordered model of $\left(\mathrm{NH}_{4}\right)_{3}\left[\mathrm{Ti}\left(\mathrm{O}_{2}\right) \mathrm{F}_{5}\right]$ [90] served as the initial coordinates for determination of the crystal structure of $\mathrm{K}_{3}\left[\mathrm{Ti}\left(\mathrm{O}_{2}\right) \mathrm{F}_{5}\right]$ [91]. This compound is cubic, $F m \overline{3} m$. The Ti-F(1) and Ti-F(2) bond lengths are 1.894(5) and $1.88 \AA$, respectively; the Ti-O distance is $1.98(2) \AA$. 
Unlike cubic $\mathrm{A}_{3}\left[\mathrm{Ti}\left(\mathrm{O}_{2}\right) \mathrm{F}_{5}\right]\left(\mathrm{A}=\mathrm{NH}_{4}{ }^{+}, \mathrm{K}^{+}\right), \mathrm{Ba}_{3}\left[\mathrm{Ti}\left(\mathrm{O}_{2}\right) \mathrm{F}_{5}\right]_{2} \cdot 2 \mathrm{H}_{2} \mathrm{O}$ crystallizes in the tetragonal symmetry, space group $\mathrm{P}_{2} / m b c$ [92]. The structure of $\mathrm{Ba}_{3}\left[\mathrm{Ti}_{(}\left(\mathrm{O}_{2}\right) \mathrm{F}_{5}\right]_{2} \cdot 2 \mathrm{H}_{2} \mathrm{O}$, just like that of $\mathrm{A}_{3}\left[\mathrm{Ti}\left(\mathrm{O}_{2}\right) \mathrm{F}_{5}\right]$, contains isolated complex $\left[\mathrm{Ti}\left(\mathrm{O}_{2}\right) \mathrm{F}_{5}\right]^{3-}$ anions, whose geometry can be represented as pentagonal-bipyramidal rather than octahedral. Three $\mathrm{F}$ atoms and $\mathrm{O}$ atoms of the peroxo-group form a rather distorted equatorial plane of the pentagonal bipyramid; $\mathrm{F}$ atoms occupy the axial positions. The longest Ti-F bond (2.090(8) $\AA$ ) corresponds to the Ti atom bound to the $\mathrm{F}$ atom located trans to the $\mathrm{O}_{2}{ }^{2-}$ group. The distance between the $\mathrm{O}$ atoms in the $\mathrm{O}_{2}{ }^{2-}$ group is typical for the peroxo-group and equal to $1.458(8) \AA$.

The structure of monomeric $\mathrm{K}_{3}\left[\mathrm{Ti}\left(\mathrm{O}_{2}\right)_{2} \mathrm{~F}_{3}\right]$ contains two coordinated peroxo-groups and was determined at two temperatures: 300 [93] and $120 \mathrm{~K}$ [94]. The $\mathrm{K}_{3}\left[\mathrm{Ti}\left(\mathrm{O}_{2}\right)_{2} \mathrm{~F}_{3}\right]$ crystals belong to the orthorhombic symmetry $\left(C m c 2_{1}\right)$. The structure of $\mathrm{K}_{3}\left[\mathrm{Ti}\left(\mathrm{O}_{2}\right)_{2} \mathrm{~F}_{3}\right]$ is composed of isolated monomeric $\left[\mathrm{Ti}\left(\mathrm{O}_{2}\right)_{2} \mathrm{~F}_{3}\right]^{3-}$ complex anions and $\mathrm{K}^{+}$cations. The Ti atom coordination polyhedron has a distorted pentagonal-bipyramidal structure (Fig. 12). The120 K structure remained virtually unchanged from that at $300 \mathrm{~K}$. The Ti-F and Ti-O bond lengths undergo no detectable changes upon transition from the room- to the low-temperature structure (Table 1). There are two crystallographically independent potassium atoms $(\mathrm{K}(1)$ and $\mathrm{K}(2))$ with different coordination numbers: 10 and 7, respectively. The $\mathrm{K}(1)-(\mathrm{O}, \mathrm{F})$ and $\mathrm{K}(2)-(\mathrm{O}, \mathrm{F})$ distances change in the ranges 2.693-3.227 and 2.505-3.183 $\AA$, respectively

Fig. 12 here

\subsection{Dimeric structures}

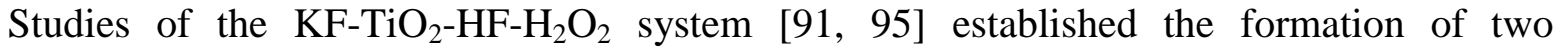
peroxofluoride complexes of $\mathrm{Ti}(\mathrm{IV})$ : $\mathrm{K}_{2} \mathrm{Ti}\left(\mathrm{O}_{2}\right) \mathrm{F}_{4} \cdot \mathrm{H}_{2} \mathrm{O}$ (orange) and $\mathrm{K}_{2} \mathrm{Ti}_{(}\left(\mathrm{O}_{2}\right) \mathrm{F}_{4} \cdot 0.5 \mathrm{H}_{2} \mathrm{O}$ (yellow). The compounds $\mathrm{K}_{2} \mathrm{Ti}\left(\mathrm{O}_{2}\right) \mathrm{F}_{4} \cdot \mathrm{H}_{2} \mathrm{O}$ [95] and $\mathrm{K}_{2} \mathrm{Ti}\left(\mathrm{O}_{2}\right) \mathrm{F}_{4} \cdot 0.5 \mathrm{H}_{2} \mathrm{O}$ [96] have similar crystal structures composed of isolated dimeric $\left[\mathrm{Ti}_{2}\left(\mathrm{O}_{2}\right)_{2} \mathrm{~F}_{8}\right]^{4-}$ complex anions, $\mathrm{K}^{+}$cations, and crystallization $\mathrm{H}_{2} \mathrm{O}$ molecules. Dimeric $\left[\mathrm{Ti}_{2}\left(\mathrm{O}_{2}\right)_{2} \mathrm{~F}_{8}\right]^{4-}$ anions are composed of two pentagonalbipyramidal $\mathrm{Ti}\left(\mathrm{O}_{2}\right) \mathrm{F}_{5}$ groups linked by a double bridging fluoride bond, with the middle point coinciding with the symmetry center (Fig. 13). 
Fig. 13 here

The anion geometry differs insignificantly in the two structures and mainly concern the bonding of the dimeric $\left[\mathrm{Ti}_{2}\left(\mathrm{O}_{2}\right)_{2} \mathrm{~F}_{8}\right]^{4-}$ anions and the role of $\mathrm{H}_{2} \mathrm{O}$ molecules in crystal assembly. In $\mathrm{K}_{2} \mathrm{Ti}\left(\mathrm{O}_{2}\right) \mathrm{F}_{4} \cdot \mathrm{H}_{2} \mathrm{O}$ the dimeric anions are linked to each other through hydrogen bonds between $\mathrm{H}_{2} \mathrm{O}$ molecules and $\mathrm{F}$ atoms and form chains directed along the crystal $c$ axis, whereas in $\mathrm{K}_{2} \mathrm{Ti}\left(\mathrm{O}_{2}\right) \mathrm{F}_{4} \cdot 0.5 \mathrm{H}_{2} \mathrm{O}$ the anions are in parallel to each other and localized in layers parallel to the (100) plane of the crystal.

The $\mathrm{H}_{2} \mathrm{O}$ molecules do not have a definite structure-forming role in $\mathrm{K}_{2} \mathrm{Ti}\left(\mathrm{O}_{2}\right) \mathrm{F}_{4} \cdot 0.5 \mathrm{H}_{2} \mathrm{O}$. They are located in structural channels relatively far from nearest $\mathrm{F}$ and $\mathrm{O}$ atoms, which prevents their involvement in any hydrogen bond formation. In the structure of $\mathrm{K}_{2} \mathrm{Ti}\left(\mathrm{O}_{2}\right) \mathrm{F}_{4} \cdot \mathrm{H}_{2} \mathrm{O}$, the distance between $\mathrm{O}$ atoms of $\mathrm{H}_{2} \mathrm{O}$ molecules and $\mathrm{F}$ atoms are 2.75 and $2.78 \AA$, while in $\mathrm{K}_{2} \mathrm{Ti}\left(\mathrm{O}_{2}\right) \mathrm{F}_{4} \cdot 0.5 \mathrm{H}_{2} \mathrm{O}$ they are 3.47 and $3.53 \AA$. The Ti-F and Ti-O bond lengths are virtually identical in both structures (Table 1).

The compound $\mathrm{K}_{4}\left[\mathrm{Ti}_{2}\left(\mathrm{O}_{2}\right)_{2} \mathrm{~F}_{8}\right] \cdot \mathrm{H}_{2} \mathrm{O}_{2}$ [97] and $\mathrm{K}_{2} \mathrm{Na}_{2}\left[\mathrm{Ti}_{2}\left(\mathrm{O}_{2}\right)_{2} \mathrm{~F}_{8}\right] \cdot \mathrm{H}_{2} \mathrm{O}$ [98] are isostructural with $\mathrm{K}_{2}\left[\mathrm{Ti}\left(\mathrm{O}_{2}\right) \mathrm{F}_{4}\right] \cdot 0.5 \mathrm{H}_{2} \mathrm{O}$ [96] (Table 1). The dimeric complex anions in both compounds form layers parallel to the (100) plane. The $\mathrm{H}_{2} \mathrm{O}$ molecules and $\mathrm{K}$ atoms are located between the layers. The coordination numbers of the $\mathrm{Na}^{+}$and $\mathrm{K}^{+}$ions in $\mathrm{K}_{2} \mathrm{Na}_{2}\left[\mathrm{Ti}_{2}\left(\mathrm{O}_{2}\right)_{2} \mathrm{~F}_{8}\right] \cdot \mathrm{H}_{2} \mathrm{O}$ is 6 . The $\mathrm{Na}^{+}$ ions link the dimeric complexes into layers. The average Na-F distance is $2.365 \AA$. The $\mathrm{K}$ atoms connect these layers by bonding to three terminal $\mathrm{F}$ atoms and two $\mathrm{O}$ atoms of three adjacent dimeric complexes as well as to the $\mathrm{H}_{2} \mathrm{O}$ molecule. Hydrogen bonds $\mathrm{O}-\mathrm{H} \cdots \mathrm{F}$ and $\mathrm{O}-\mathrm{H} \cdots \mathrm{O}$ (2.724(4), 2.742(4) $\AA$ ) formed by $\mathrm{H}_{2} \mathrm{O}$ molecules with the $\mathrm{F}$ atom and the peroxo-group $\mathrm{O}$ atom link layers into a three-dimensional structure.

\section{Conclusions}


The main characteristic feature of the structural chemistry of fluoride and oxofluoride complexes of titanium(IV) is the constant coordination number of the Ti atom in all studied crystal structures $(\mathrm{CN}=6)$. Octahedral groups $\mathrm{TiF}_{6}, \mathrm{TiF}_{5}\left(\mathrm{H}_{2} \mathrm{O}\right), \mathrm{TiF}_{5} \mathrm{O}, \mathrm{TiF}_{4} \mathrm{O}_{2}$, and $\mathrm{Ti}(\mathrm{F}, \mathrm{OH})_{6}$ serve as basic units in the structures of fluoride and oxofluoride complexes of titanium(IV).

The structural chemistry of fluoride and oxofluoride complexes of titanium(IV) is substantially different from that for the elements of the same subgroup: zirconium(IV) and hafnium(IV) [5], whose structures a wider and higher range of coordination numbers of the metal ion (from 6 to 8) and different configurations of polyhedra and structural motifs. Isolated octahedral $\left[\mathrm{TiF}_{6}\right]^{2-}$ complex anions are observed in crystal structures of a large range of compounds with differing cations including alkali metal ions, $\mathrm{NH}_{4}{ }^{+}$, mixed cations of alkali metals and $\mathrm{NH}_{4}{ }^{+}$, protonated cations of organic bases, and complex cations of divalent and trivalent transition metals $\left(\mathrm{Co}^{3+}\right.$ and $\left.\mathrm{Rh}^{3+}\right)$. The crystal structures of hexafluoridotitanaic(IV) acids and a series of titanium(IV) double hexafluoride complexes were studied as well (Table 1).

Octahedral complex anions $\left[\mathrm{TiF}_{6}\right]^{2-}$ can be fused to form dimeric, oligomeric, and polymeric complex anions. Isolated vertex-sharing dinuclear $\left[\mathrm{Ti}_{2} \mathrm{~F}_{11}\right]^{3-}$ complex anions are present in the crystal structures of $\left(\mathrm{C}_{5} \mathrm{H}_{5} \mathrm{NH}\right)_{2}\left(\mathrm{H}_{3} \mathrm{O}\right)\left[\mathrm{Ti}_{2} \mathrm{~F}_{11}\right] \cdot \mathrm{H}_{2} \mathrm{O}$ [63] and [ $\left.\mathrm{ImH}\right]_{3}\left[\mathrm{Ti}_{2} \mathrm{~F}_{11}\right]$ [41]. The crystal structures of fluoride complexes of $\mathrm{Ti}(\mathrm{IV})$ with edge-sharing dimeric $\left[\mathrm{Ti}_{2} \mathrm{~F}_{10}\right]^{2-}$ anions were also reported [65, 66]. Oligomeric fluoride complexes are represented by compounds containing isolated tetrameric $\left[\mathrm{Ti}_{4} \mathrm{~F}_{18}\right]^{2-},\left[\mathrm{Ti}_{4} \mathrm{~F}_{19}\right]^{3-}$, and $\left[\mathrm{Ti}_{4} \mathrm{~F}_{20}\right]^{4-}$, pentameric $\left[\mathrm{Ti}_{5} \mathrm{~F}_{23}\right]^{3-}$, and octameric $\left[\mathrm{Ti}_{8} \mathrm{~F}_{36}\right]^{4-}$ anions.

Two types of polymeric chain structures of fluoride complexes of Ti(IV) have been reported. In the one-dimensional chain structures of $\left(\mathrm{H}_{3} \mathrm{O}\right) \mathrm{TiF}_{5}$ [72] and $\left(\mathrm{NH}_{4}\right) \mathrm{TiF}_{5}$ [73], octahedral $\mathrm{TiF}_{6}$ groups are linked to each other via cis-fluorine atoms. Double chain structures contain $\mathrm{TiF}_{6}$ groups, each bound to an adjacent one via three $\mathrm{F}$ vertices. The polymeric $\left[\mathrm{Ti}_{8} \mathrm{~F}_{33}\right]^{-}$ anion in $\mathrm{CsTi}_{8} \mathrm{~F}_{33}$ [74] has a layered structure, while the compound $\left(\mathrm{O}_{2}\right)_{2} \mathrm{Ti}_{7} \mathrm{~F}_{30}$ [75] (as $\left.\mathrm{TiF}_{4}[76]\right)$ displays a column structure. Very recently, Radan et al. isolated $\left[\mathrm{Xe}_{2} \mathrm{~F}_{3}\right]\left[\mathrm{Ti}_{8} \mathrm{~F}_{33}\right]$ and $[\mathrm{XeF}]_{2}\left[\mathrm{Ti}_{9} \mathrm{~F}_{38}\right]$ upon heating $\mathrm{XeF}_{2}$ in the presence of $\mathrm{TiF}_{4}$ [138]. The [ $\left.\mathrm{Ti}_{8} \mathrm{~F}_{33}\right]$-anion in $\left[\mathrm{Xe}_{2} \mathrm{~F}_{3}\right]\left[\mathrm{Ti}_{8} \mathrm{~F}_{33}\right]$ displays a $2 \mathrm{D}$ anion formed from eight fused $\mathrm{TiF}_{6}$ octahedra, while $\left[\mathrm{Ti}_{9} \mathrm{~F}_{38}\right]^{2-}$ in $[\mathrm{XeF}]_{2}\left[\mathrm{Ti}_{9} \mathrm{~F}_{38}\right]$ forms a novel 1D-polyanion and consists of $\mathrm{Ti}_{3} \mathrm{~F}_{15}$ building blocks with three $\mathrm{TiF}_{6}$ octahedra sharing two cis vertices. The $\left[\mathrm{Ti}_{9} \mathrm{~F}_{38}\right]^{2-}$ polyanion has a columnar structure and 
with nine fused $\mathrm{Ti}$ atoms represents the largest association among polymeric fluoridotitanates(IV) [138].

In the series of crystal structures of hexafluoridotitanates(IV), just a few complexes contain regular octahedral $\left[\mathrm{TiF}_{6}\right]^{2-}$ complex anions with $\mathrm{Ti}-\mathrm{F}$ distances in the octahedron only slightly differing from $1.860 \AA$ and F-Ti-F angles equal virtually to 90 or $180^{\circ}$ (Table). In the all other structures of the hexafluoridotitanates(IV), octahedral $\left[\mathrm{TiF}_{6}\right]^{2-}$ anions are distorted, and the degree of distortion (and, therefore, the Ti-F bond lengths in the anion) depend on the F atoms participate in hydrogen bonding (Table 1). Formation of the bridging Ti-F-Ti bond is accompanied by redistribution of Ti-F bond lengths in octahedral groups building the complex anion. Thus, the structurally studied fluoride and oxofluoride complexes of Ti(IV) display Ti-

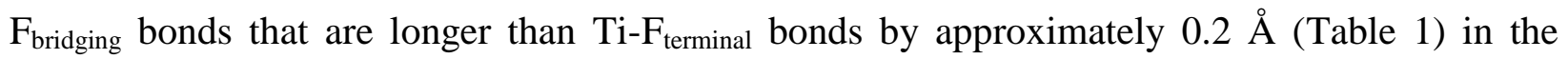
absence of hydrogen bonding to the terminal fluorines.

It has to be noted that the crystal structures of oxo-, hydroxy-, and peroxofluoride complexes of titanium(IV) have been studied insufficiently. In these structures, the same types of complex anions (from monomeric to polymeric) occur as in the structures fluoride complexes of Ti(IV) (Table 1). Hydroxyfluoridotitanate $\left[\mathrm{Ti}(\mathrm{F}, \mathrm{OH})_{6}\right]^{2-}$ anions display isolated, monomeric octahedra with randomly distributed $\mathrm{F}$ and $\mathrm{OH}$ ligands. The crystal structures of monomeric and dimeric peroxofluoride complexes of $\mathrm{Ti}(\mathrm{IV})$ display disordered cubic structures of general formula $\mathrm{A}_{3}\left[\mathrm{Ti}\left(\mathrm{O}_{2}\right) \mathrm{F}_{5}\right]$. The $\mathrm{Ti}(\mathrm{IV})$ coordination polyhedron in $\left[\mathrm{Ti}\left(\mathrm{O}_{2}\right) \mathrm{F}_{5}\right]^{3-}$ can be presented as a pentagonal bipyramid with one shortened $\mathrm{O}-\mathrm{O}$ distance on one of the vertices, or alternatively as octahedra of the elpasolite structural type.

Although the driving forces behind supramolecular crystal assembly in fluoridotitanate(IV) complexes are not always easy to quantify, it is clear that non-covalent intermolecular interactions, such as hydrogen bonding, ion-ion/ion-dipole/dipole-dipole interactions, $\pi-\pi$ stacking, as well as van der Waals forces, can play an important role in determining the crystal growth and packing. The sequence of creation of supramolecular fluoridotitanate(IV) lattices can be described first as the formation of 1D structures, 2D layers next, and their final assembly into 3D lattices. Studying the basic phenomena responsible for the supramolecular assembly on the example of fluoridotitanate(IV) complexes is attractive and can be very informative [138], as fluoride ligands belong to the most fundamental systems in coordination chemistry. 
Further studies of the structural chemistry of fluoride and oxo-, hydroxy-, and peroxofluoride complexes of titanium(IV) are of great interest in view of obtaining new data on Ti(IV) stereochemistry and creating the basic principles for rational design and synthesis of new Ti(IV) fluoride compounds and materials, and revealing the possibilities of formation fluoride complexes of titanium(IV) with framework anions. Up to present, such complexes of Ti(IV) have not yet been obtained. Therefore, there is a need for additional studies to further understand the structure-property relationships in titanium fluoride complexes, which could enable the rational design and synthesis of novel structures with desired characteristics.

Acknowledgments. KHW thanks the Robert A. Welch Foundation for financial support (C0976).

\section{References}

[1] R.L. Davidovich, Koord. Khim. 24 (1998) 803-821 (Russ. J. Coord. Chem. 24 (1998) 751-768).

[2] R.L. Davidovich, Koord. Khim. 25 (1999) 243-255 (Russ. J. Coord. Chem. 25 (1999) 225-236).

[3] V. Stavila, R.L. Davidovich, A. Gulea, K.H. Whitmire, Coord. Chem. Rev. 250 (2006) 27822810.

[4] R.L. Davidovich, V. Stavila, D.V. Marinin, E.I. Voit, K.H. Whitmire, Coord. Chem. Rev. 253 (2009) 1316-1352.

[5] R.L. Davidovich, V. Stavila, K.H. Whitmire, Coord. Chem. Rev. 254 (2010) 2193-2226.

[6] R.L. Davidovich, D.V. Marinin, V. Stavila, K.H. Whitmire, Coord. Chem. Rev. 257 (2013) 30743088.

[7] G.B. Nikiforov, H.W. Roesky, D. Koley, Coord. Chem. Rev. 258-259 (2014) 16-57.

[8] H.W. Roesky, I. Haiduc, J. Chem. Soc., Dalton Trans. (1999) 2249-2264.

[9] E.F. Murphy, R. Murugavel, H.W. Roesky, Chem. Rev. 97 (1997) 3425-3468.

[10] S.L. Benjamin, W. Levason, G. Reid, Chem. Soc. Rev. 42 (2013) 1460-1499.

[11] M. Melnik, D. Cozak, Revs. Inorg. Chem. 8 (1986) 221-285.

[12] V.G. Yagodin, V.E. Mistryukov, V.I. Pakhomov, Y.N. Mikhailov, E.G. Il'in, Y.A. Buslaev, Zh. Neorg. Khim. 32 (1987) 2589-2592. 
[13] D. Mootz, E.-J. Oellers, M. Wiebcke, Z. Anorg. Allg. Chem. 564 (1988) 17-25.

[14] S. Siegel, Acta Crystallogr. 5 (1952) 683-684.

[15] O. Göbel, Acta Crystallogr. C56 (2000) 521-522.

[16] D.V. Peryshkov, R. Friedemann, E. Goreshnik, Z. Mazej, K. Seppelt, S.H. Strauss, J. Fluor. Chem. 145 (2013) 118-127.

[17] D.Yu. Popov, V.Ya. Kavun, A.V. Gerasimenko, V.I. Sergienko, T.F. Antokhina, Koord. Khim. 28 (2002) 21-26 (Russ. J. Coord. Chem. 28 (2002) 19-24).

[18] Z. Tun, I.D. Brown, Acta Crystallogr. B38 (1982) 1792-1794.

[19] J.-H. Chang, J. Köhler, Mater. Res. Bull. 35 (2000) 25-32.

[20] J. Portier, A. Tressaud, F. Menil, J. Claverie, R. de Pape, P. Hagenmuller, J. Solid State Chem. 1 (1969) 100-102.

[21] E.A. Marseglia, I.D. Brown, Acta Crystallogr. B29 (1973) 1352-1354.

[22] G.F. Schäfer, Z. Kristallogr. 175 (1986) 269-276.

[23] D.Yu. Popov, T.F. Antokhina, A.V. Gerasimenko, V.I. Sergienko, Zh. Neorg. Khim. 43 (1998) 1770-1772.

[24] D.Yu. Popov, V.Ya. Kavun, T.F. Antokhina, A.V. Gerasimenko, V.I. Sergienko, Koord. Khim. 27 (2001) 883-886 (Russ. J. Coord. Chem. 27 (2001) 831-834).

[25] A.V. Gerasimenko, V.Ya. Kavun, T.F. Antokhina, V.I. Sergienko, Zh. Neorg. Khim. 40 (1995) 1463-1465.

[26] D.Yu. Popov, T.F. Antokhina, A.V. Gerasimenko, T.A. Kaidalova, V.I. Sergienko, Koord. Khim. 30 (2004) 29-31 (Russ. J. Coord. Chem. 30 (2004) 27-29).

[27] O.F. Göbel, G.J. van Hummel, J.E. ten Elshof, Z. Kristallogr. 226 (2011) 78-82.

[28] E. Kim, D.W. Lee, K.M. Ok, J. Solid State Chem. 195 (2012) 149-154.

[29] O.F. Göbel, J.E. ten Elshof, A.M.M. Schreurs, Z. Kristallogr. 226 (2011) 748-755.

[30] L. Kiriazis, R. Mattes, Z. Anorg. Allg. Chem. 593 (1991) 90-98.

[31] I. Ban, M. Kristl, B. Volavšek, L. Golič, Monatsh. Chem. 130 (1999) 401-408.

[32] G. Liu, G. Li, F. Liao, J. Lin, Acta Phys.-Chim. Sin. 24 (2008) 1945-1949.

[33] M.L. Afanasiev, A.D. Vasiliev, V.V. Lisin, A.M. Nazarov, A.A. Sukhovskii, Zh. Strukt. Khim. 38 (1997) 669-675 (J. Struct. Chem. 38 (1997) 556-561).

[34] J. Lhoste, K. Adil, M. Leblanc, V. Maisonneuve, Acta Crystallogr. E64 (2008) m1375.

[35] I. Leban, A. Jesih, A. Rahten, Acta Crystallogr. C50 (1994) 842-843.

[36] B. Kojić-Prodić, B. Matković, S. Šćavničar, Acta Crystallogr. B27 (1971) 635-637. 
[37] U. Calov, M. Schneider, P. Leibnitz, Z. Anorg. Allg. Chem. 604 (1991) 77-83.

[38] A. Pevec, M. Tekavec, A. Demšar, Polyhedron 30 (2011) 549-555.

[39] M.S. Dadachov, L.-Q. Tang, X.-D. Zou, Z. Kristallogr. NCS 215 (2000) 607-608.

[40] S.A. Lermontov, A.N. Malkova, E.Kh. Lermontova, A.V. Churakov, Zh. Obsh. Khim. 80 (2010) 1507-1512 (Russ. J. Gener. Chem. 80 (2010) 1825-1830).

[41] I.M. Shlyapnikov, H.P.A. Mercier, E.A. Goreshnik, G.J. Schrobilgen, Z. Mazej, Inorg. Chem. 52 (2013) 8315-8326.

[42] S.G. Minasian, K.S. Boland, R.K. Feller, A.J. Gaunt, S.A. Kozimor, I. May, S.D. Reilly, B.L. Scott, D.K. Shuh, Inorg. Chem. 51 (2012) 5728-5736.

[43] T. Chattopadhyay, F. Devreux, K. Peters, E.-M. Peters, E. Gmelin, B. Ghosh, J. Phys. C: Solid State Phys. 21 (1988) 1321-1334.

[44] G. Mostafa, S. Ray, A. Mukhopadhyay, Z. Kristallogr. 211 (1996) 373-377.

[45] P. Halasyamani, M.J. Willis, C.L. Stern, K.R. Poeppelmeier, Inorg. Chim. Acta 240 (1995) 109115.

[46] É.B. Miminoshvili, T.N. Sakvarelidze, K.É. Miminoshvili, Zh. Strukt. Khim. 53 (2012) 10241028 (J. Struct. Chem. 53 (2012) 1006-1010).

[47] J. Fischer, G. Keib, R. Weiss, Acta Crystallogr. 22 (1967) 338-340.

[48] B.V. Bukvetskii, R.L. Davidovich, V.I. Simonov, Koord. Khim. 1 (1975) 1558-1561.

[49] B.V. Bukvetskii, L.A. Muradyan, M.A. Simonov, V.I. Simonov, Kristallografiya 24 (1979) 2937.

[50] Y.V. Kokunov, I.E. Rakov, Y.A. Buslaev, A.V. Yatsenko, L.A. Aslanov, J. Fluor. Chem. 52 (1991) 209-219.

[51] J.-H. Chang, J. Köhler, Z. Anorg. Allg. Chem. 626 (2000) 241-245.

[52] R. Weiss, J. Fischer, B. Chevrier, Acta Crystallogr. 20 (1966) 534-537.

[53] A. Decian, J. Fischer, R. Weiss, Acta Crystallogr. 22 (1967) 340-343.

[54] L. Golič, V. Kaučič, B. Kojić-Prodić, Acta Crystallogr. B36 (1980) 659-661.

[55] J. Lhoste, K. Adil, A. Le Bail, M. Leblanc, A. Hémon-Ribaud, V. Maisonneuve, J. Fluor. Chem. 134 (2012) 29-34.

[56] A.J. Norquist, K.R. Heier, C.L. Stern, K.R. Poeppelmeier, Inorg. Chem. 37 (1998) 6495-6501.

[57] P.A. Maggard, A.L. Kopf, C.L. Stern, K.R. Poeppelmeier, CrystEngComm. 6 (2004) 451-457.

[58] S. Noro, S. Kitagawa, Stud. Surf. Sci. Catal. 141 (2002) 363-370. 
[59] P. Nugent, V. Rhodus, T. Pham, B. Tudor, K. Forrest, L. Wojtas, B. Space, M. Zaworotko, Chem. Commun. 49 (2013) 1606-1608.

[60] A. Rija, E. Coropceanu, O. Bologa, V. Lozan, J. Lipkowski, I. Bulhac, P. Bourosh, Zh. Neorg. Khim. 58 (2013) 506-516 (Russ. J. Inorg. Chem. 58 (2013) 440-449).

[61] A.P. Rija, A. Nicolescu, A. Soran, E.B. Coropceanu, I.I. Bulhac, O.A. Bologa, C. Deleanu, P.N. Bourosh, Koord. Khim. 37 (2011) 759-767 (Russ. J. Coord. Chem. 37 (2011) 757-765).

[62] P.N. Bourosh, E.B. Coropceanu, A.P. Rija, O.A. Bologa, M. Gdaniec, I.I. Bulhac, J. Mol. Struct. 998 (2011) 198-205.

[63] L.-Q. Tang, M.S. Dadachov, X.-D. Zou, Z. Kristallogr. NCS 216 (2001) 387-388.

[64] R.L. Davidovich, V.V. Tkachev, V.B. Logvinova, V.I. Kostin, V. Stavila, Zh. Strukt. Khim. 55 (2014) 969-972 (J. Struct. Chem. 55 (2014) 923-926).

[65] H. Akutsu, K. Ozeki, T. Ozaki, K. Nozawa, M. Kinoshita, K. Kozawa, T. Uchida, Bull. Chem. Soc. Jpn. 69 (1996) 1869-1873.

[66] M.S. Dadachov, L.-Q. Tang, X.-D. Zou, Z. Kristallogr. NCS 215 (2000) 605-606.

[67] A. Decken, H.D.B. Jenkins, C. Knapp, G.B. Nikiforov, J. Passmore, J.M. Rautiainen, Angew. Chem. Int. Ed. 44 (2005) 7958-7961.

[68] Z. Mazej, E. Goreshnik, Inorg. Chem. 48 (2009) 6918-6923.

[69] M. Jura, W. Levason, E. Petts, G. Reid, M. Webster, W. Zhang, Dalton Trans. 39 (2010) 1026410271.

[70] Z. Mazej, E. Goreshnik, Eur. J. Inorg. Chem. (2009) 4503-4506.

[71] I.M. Shlyapnikov, E.A. Goreshnik, Z. Mazej, Chem. Commun. 49 (2013) 2703-2705.

[72] S. Cohen, H. Selig, R. Gut, J. Fluor. Chem. 20 (1982) 349-356.

[73] V.Ya. Kavun, B.V. Bukvetskii, N.M. Laptash, I.G. Maslennikova, S.S. Sergienko, Zh. Strukt. Khim. 42 (2001) 921-927 (J. Struct. Chem. 42 (2001) 771-776).

[74] H. Bialowons, B.G. Müller, Z. Anorg. Allg. Chem. 621 (1995) 1223-1226.

[75] B.G. Müller, J. Fluor. Chem. 17 (1981) 489-499.

[76] H. Bialowons, M. Müller, B.G. Müller, Z. Anorg. Allg. Chem. 621 (1995) 1227-1231.

[77] G. Pausewang, W. Rüdorff, Z. Anorg. Allg. Chem. 364 (1969) 69-87.

[78] A.A. Udovenko, N.M. Laptash, Acta Crystallogr. B67 (2011) 447-454.

[79] A.A. Udovenko, N.M. Laptash, I.G. Maslennikova, J. Fluor. Chem. 124 (2003) 5-15.

[80] L.-Q. Tang, M.S. Dadachov, X.-D. Zou, Z. Kristallogr. NCS 216 (2001) 259-260.

[81] M.S. Dadachov, L.-Q. Tang, X.-D. Zou, Z. Kristallogr. NCS 216 (2001) 141-142. 
[82] A. Penicaud, P. Batail, K. Bechgaard, J. Sala-Pala, Synt. Met. 22 (1988) 201-207.

[83] L.-Q. Tang, M.S. Dadachov, X.-D. Zou, Z. Kristallogr. NCS 216 (2001) 257-258.

[84] J. Lhoste, R. Gervier, V. Maisonneuve, M. Leblanc, K. Adil, Solid State Sciences 11 (2009) 1582-1586.

[85] J. Lhoste, X. Rocquefelte, K. Adil, R. Dessapt, S. Jobic, M. Leblanc, V. Maisonneuve, M. Bujoli-Doeuff, Inorg. Chem. 50 (2011) 5671-5678.

[86] J. Lhoste, C. Galven, M. Leblanc, V. Maisonneuve, X. Rocquefelte, S. Jobic, M. Bujoli-Doeuff, Solid State Sciences 24 (2013) 101-106.

[87] R. Stomberg, I. Svensson, Acta Chem. Scand. A31 (1977) 635-637.

[88] Ž. Ružić-Toroš, B. Kojić-Prodić, M. Šljukić, Inorg. Chim. Acta 86 (1984) 205-208.

[89] W. Massa, G. Pausewang, Mater. Res. Bull. 13 (1978) 361-368.

[90] R. Schmidt, G. Pausewang, W. Massa, Z. Anorg. Allg. Chem. 535 (1986) 135-142.

[91] R. Schmidt, G. Pausewang, Z. Anorg. Allg. Chem. 537 (1986) 175-188.

[92] R. Schmidt, G. Pausewang, Z. Anorg. Allg. Chem. 575 (1989) 197-201.

[93] A.V. Gerasimenko, B.V. Bukvetskii, B.N. Chernyshov, N.A. Didenko, Zh. Neorg. Khim. 35 (1990) 1611-1613.

[94] E.I. Overchuk, V.I. Sergienko, B.V. Bukvetskii, Zh. Neorg. Khim. 39 (1994) 887-891.

[95] R. Schmidt, W. Hiller, G. Pausewang, Z. Naturforsch. 38b (1983) 849-851.

[96] R. Schmidt, G. Pausewang, Z. Anorg. Allg. Chem. 559 (1988) 135-142.

[97] B.N. Chernyshov, N.A. Didenko, B.V. Bukvetskii, A.V. Gerasimenko, V.Ya. Kavun, Zh. Neorg. Khim. 34 (1989) 2179-2186.

[98] B.V. Bukvetskii, B.N. Chernyshov, N.A. Didenko, N.G. Bakeeva, Zh. Neorg. Khim. 40 (1995) 1085-1088.

[99] D. Mootz, E.-J. Oellers, Z. Anorg. Allg. Chem. 559 (1988) 27-39.

[100] B. Cox, A.G. Sharp, J. Chem. Soc. (1953) 1783-1784.

[101] F. Hanic, Chem. Zvesti 20 (1966) 738-751.

[102] R.L. Davidovich, T.A. Kaidalova, T.F. Levchishina, V.I. Sergienko, Atlas of Infrared Absorption Spectra and X-Ray Diffraction Data on Complex Fluorides of Group IV and V Metals. Moscow, Nauka, 1972. P. 252 (In Russian).

[103] J.L. Hoard, W.B. Vincent, J. Am. Chem. Soc. 61 (1939) 2849-2852.

[104] H. Bode, W. Wendt, Z. Anorg. Allg. Chem. 269 (1952) 165-172.

[105] R.J. Williams, D.R. Dillin, W.O. Milligan, Acta Crystallogr. B29 (1973) 1369-1372. 
[106] E.O. Schlemper, W.C. Hamilton, J. Chem. Phys. 45 (1966) 408-409.

[107] E.O. Schlemper, W.C. Hamilton, J.J. Rush, J. Chem. Phys. 44 (1966) 2499-2505.

[108] H.M. Rietveld, J. Appl. Crystallogr. 2 (1969) 65-71.

[109] R.N. Singh, D.K. Padma, Synth. React. Inorg. Met.-Org. Chem. 25 (1995) 653-662.

[110] A.F. Wells. Structural Inorganic Chemistry. $5^{\text {th }}$ Edition. Oxford University Press, 1984. P. 250.

[111] B. Cox, J. Chem. Soc. (1954) 3251-3252.

[112] A. Zalkin, J.D. Forrester, D.H. Templeton, Acta Crystallogr. 17 (1964) 1408-1412.

[113] R.W. Berg, I. Søtofte, Acta Chcm. Scand. A32 (1978) 241-244.

[114] O. Knop, T.S. Cameron, M.A. Janes, Can. J. Chem. 61 (1983) 1620-1646.

[115] H. Küppers, O. Göbel, C. Bruhn, W. Preetz, A. Pietraszko, Z. Kristallogr. 214 (1999) 178-183.

[116] H. Küppers, O. Göbel, C. Bruhn, W.W. Schmahl, Z. Kristallogr. 216 (2001) 354-360.

[117] A. Pevec, A. Demšar, J. Fluor. Chem. 129 (2008) 707-712.

[118] W.C. Hamilton, Acta Crystallogr. 15 (1962) 353-360.

[119] S. Ray, A. Zalkin, D.H. Templeton, Acta Crystallogr. B29 (1973) 2741-2747.

[120] B.F. Hoskins, A. Linden, Aust. J. Chem. 40 (1987) 565-577.

[121] W. Mikenda, F. Pertlik, S. Steinböck, Monatsh. Chem. 126 (1995) 61-66.

[122] L. Pauling, Z. Kristallogr. 72 (1930) 482-492.

[123] J. Fischer, A. De Cian, R. Weiss, Bull. Soc. Chim. France (1966) 2646-2647.

[124] S. Syoyama, K. Osaki, Acta Crystallogr. B28 (1972) 2626-2627.

[125] C. Billy, H.M. Haendler, J. Am. Chem. Soc. 79 (1957) 1049-1051.

[126] B.L. McGaw, J.A. Ibers, J. Chem. Phys. 39 (1963) 2677-2684.

[127] R. Weiss, B. Chevrier, J. Fischer, Compt. Rend. Acad. Sci. Paris 260 (1965) 3664-3665.

[128] J.L. Hoard, W.J. Martin, J. Amer. Chem. Soc. 63 (1941) 11-17.

[129] A. De Cian, J. Fischer, R. Weiss, Bull. Soc. Chim. France (1966) 2647-2648.

[130] J. Slivnik, J. Maček, B. Orel, B. Sedej, Monatsh. Chem. 104 (1973) 624-632.

[131] A.A. Desyatnik, N.V. Gerbeleu, E.B. Koropchanu, Zh.P. Tyurina, S.V. Lablyuk, O.A. Bologa, S.I. Klapko, Koord. Khim. 28 (2002) 144-145 (Russ. J. Coord. Chem. 28 (2002) 135-136).

[132] P.N. Bourosh, E.B. Koropchanu, A.A. Desyantnik, O.A. Bologa, Zh.P. Tyurina, M.V. Stratan, O.A. Chiobenike, Y. Lipkovsky, I.I. Bulkhak, Y.A. Simonov, Koord. Khim. 35 (2009) 761767 (Russ. J. Coord. Chem. 35 (2009) 751-757). 
[133] P.N. Bourosh; E.B. Coropceanu, A.A. Ciloci, S.F. Clapco, O.A. Bologa, C.M. Bivol, Zh.P. Tyurina, I. Bulhac, Koord. Khim. 39 (2013) 669-678 (Russ. J. Coord. Chem. 39 (2013) 777786).

[134] G.B. Bokii, S.S. Batsanov, Zh. Strukt. Khim. 4 (1963) 80-84 (J. Struct. Chem. 4 (1963) 68-71).

[135] R. Stomberg, Acta Chem. Scand. A34 (1980) 193-198.

[136] H.J. Hurst, J.C. Taylor, Acta Crystallogr. B26 (1970) 417-421.

[137] J. Lhoste, M. Body, C. Legein, A. Ribaud, M. Leblanc, V. Maisonneuve, J. Solid State Chem. 127 (2014) 72-79.

[138] K. Radan, E. Goreshnik, B. Žemva, Angew. Chem. Int. Ed. 53 (2014) 13715-13719. 


\section{Figure captions}

Fig. 1. An ORTEP drawing of a part of the $\left(\mathrm{NMe}_{4}\right)\left[\mathrm{Ti}(2)\left(\mathrm{H}_{2} \mathrm{O}\right)_{4} \mathrm{~F}_{2}\right]\left[\mathrm{Ti}(1) \mathrm{F}_{6}\right] \cdot \mathrm{H}_{2} \mathrm{O}$ structure $(\mathrm{CCD}$ CODE SIXXAY) [30].

Fig. 2. An ORTEP drawing of the motive of the $\left[\mathrm{Ni}(\mathrm{en})_{3}\right]\left[\mathrm{TiF}_{6}\right]$ crystal structure (Cif 809594 CCDC) [55].

Fig. 3. An ORTEP drawing of the structure of the dimeric complex $\left[\mathrm{Ti}_{2} \mathrm{~F}_{11}\right]^{3-}$ anion in $\left(\mathrm{C}_{5} \mathrm{H}_{5} \mathrm{NH}\right)_{2}\left(\mathrm{H}_{3} \mathrm{O}\right)\left[\mathrm{Ti}_{2} \mathrm{~F}_{11}\right] \cdot \mathrm{H}_{2} \mathrm{O}$ (Cif 186066 CCDC) [63].

Fig. 4. An ORTEP drawing of the structure of the dimeric complex $\left[\mathrm{Ti}_{2} \mathrm{~F}_{10}\right]^{2-}$ anion in $\left(\mathrm{C}_{4} \mathrm{H}_{10} \mathrm{~N}_{2} \mathrm{H}_{2}\right)\left[\mathrm{Ti}_{2} \mathrm{~F}_{10}\right] \cdot 2 \mathrm{H}_{2} \mathrm{O}$ (Cif 153410 CCDC) [66].

Fig. 5. An ORTEP drawing of the structure of the tetrameric complex $\left[\mathrm{Ti}_{4} \mathrm{~F}_{18}\right]^{2-}$ anion in $\left(\mathrm{NMe}_{4}\right)_{2}\left[\mathrm{Ti}_{4} \mathrm{~F}_{18}\right]$ (Cif $\left.748108 \mathrm{CCDC}\right)$ [68]

Fig. 6. An ORTEP drawing of the structure of a part of the polymeric chain $\left(\mathrm{TiF}_{5}\right)_{\mathrm{n}}{ }^{-}$anion in $\left(\mathrm{NH}_{4}\right) \mathrm{TiF}_{5}$ (Cif 96102-ICSD) [73].

Fig. 7. An ORTEP drawing of the structure of the polymeric hydrogen bonded chains of the complex $\left[\mathrm{TiF}_{5}\left(\mathrm{H}_{2} \mathrm{O}\right)\right]^{-}$anions in $\left(\mathrm{C}_{7} \mathrm{H}_{9} \mathrm{NH}\right)\left[\mathrm{TiF}_{5}\left(\mathrm{H}_{2} \mathrm{O}\right)\right]$ (Cif $\left.783665 \mathrm{CCDC}\right)$ [38].

Fig. 8. An ORTEP drawing of the structure of the dimeric complex $\left[\mathrm{Ti}_{2} \mathrm{~F}_{10} \mathrm{O}\right]^{4-}$ anion in $\left(\mathrm{C}_{4} \mathrm{H}_{10} \mathrm{~N}_{2} \mathrm{H}_{2}\right)_{2}\left[\mathrm{Ti}_{2} \mathrm{~F}_{10} \mathrm{O}\right] 2 \mathrm{H}_{2} \mathrm{O}$ (Cif $170432 \mathrm{CCDC}$ ) [81].

Fig. 9. An ORTEP drawing of the structure of the dimeric complex $\left[\mathrm{Ti}_{2} \mathrm{~F}_{8}\left(\mathrm{C}_{2} \mathrm{O}_{4}\right)\right]^{2-}$ anion in $\left(\mathrm{C}_{10} \mathrm{H}_{12} \mathrm{Se}_{4}\right)_{3}\left[\mathrm{Ti}_{2} \mathrm{~F}_{8}\left(\mathrm{C}_{2} \mathrm{O}_{4}\right)\right]\left((\mathrm{TMTSF})_{3}\left[\mathrm{Ti}_{2} \mathrm{~F}_{8}\left(\mathrm{C}_{2} \mathrm{O}_{4}\right)\right]\right)(\mathrm{CCD}$ CODE GAWXIL) [82].

Fig. 10. An ORTEP drawing of the structure of a part of the polymeric $\left[\mathrm{TiF}_{4} \mathrm{O}\right]_{\mathrm{n}}{ }^{2-}$ chain in $\left(\mathrm{C}_{4} \mathrm{H}_{12} \mathrm{~N}_{2} \mathrm{H}_{2}\right)\left[\mathrm{TiF}_{4} \mathrm{O}\right]$ (Cif 161394 CCDC) [83].

Fig. 11. An ORTEP drawing of the polymeric $\left[\mathrm{Ti}(1) \mathrm{OF}_{4}\right]_{\mathrm{n}}{ }^{2-}$ and $\left[\mathrm{Ti}(2) \mathrm{OF}_{4}\right]_{\mathrm{n}}{ }^{2-}$ chains in $\left(\mathrm{enH}_{2}\right)\left(\mathrm{TiOF}_{4}\right)(\mathrm{Cif} 727240 \mathrm{CCDC})[84]$.

Fig. 12. An ORTEP drawing of the structure of the monomeric complex anion $\left[\mathrm{Ti}\left(\mathrm{O}_{2}\right)_{2} \mathrm{~F}_{3}\right]^{3-}$ in $\mathrm{K}_{3}\left[\mathrm{Ti}\left(\mathrm{O}_{2}\right)_{2} \mathrm{~F}_{3}\right]$ (Cif 39273-ICDS) [93].

Fig. 13. An ORTEP drawing of the structure of the dimeric complex $\left[\mathrm{Ti}_{2}\left(\mathrm{O}_{2}\right)_{2} \mathrm{~F}_{8}\right]^{4-}$ anion in $\mathrm{K}_{2}\left[\mathrm{Ti}\left(\mathrm{O}_{2}\right) \mathrm{F}_{4}\right] \cdot \mathrm{H}_{2} \mathrm{O}$ (Cif 37182-ICDS) [95]. 


\section{Graphical Abstract}
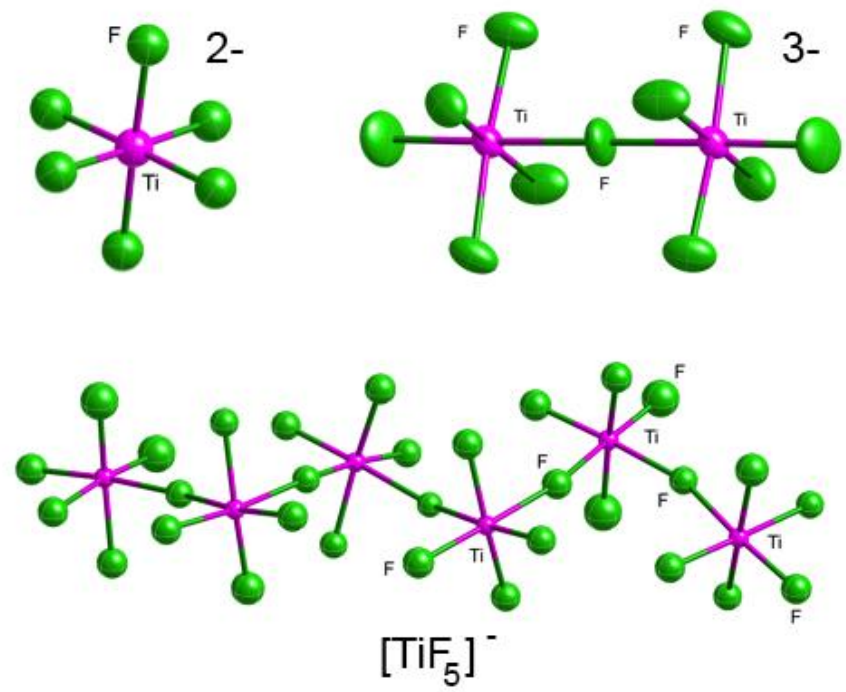

Structures of representative fluoridotitanate(IV) complex ions 


\section{Highlights}

Coordination number equal to 6 in all investigated structures of fluoride and oxofluoride complexes of Ti(IV).

- $\quad$ Octahedral groups $\mathrm{TiF}_{6}, \mathrm{TiF}_{5}\left(\mathrm{H}_{2} \mathrm{O}\right), \mathrm{TiF}_{5} \mathrm{O}, \mathrm{TiF}_{4} \mathrm{O}_{2}$, and $\mathrm{Ti}(\mathrm{F}, \mathrm{OH})_{6}$ form the basic structural units.

- Monomeric, dimeric, oligomeric, and polymeric structural motives are realized through various bridging modes. 


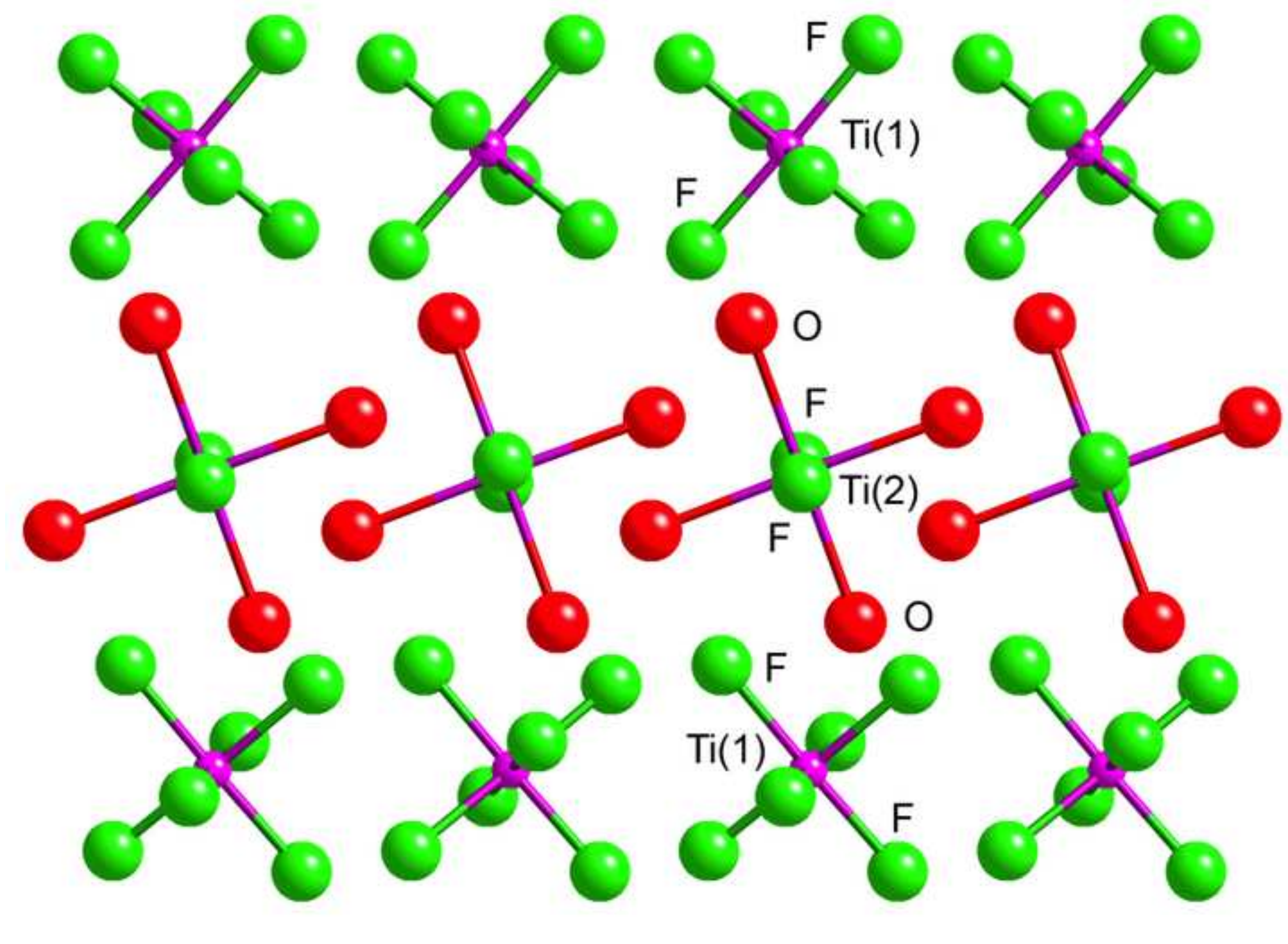

Figure(s)
Click here to download high resolution imag 

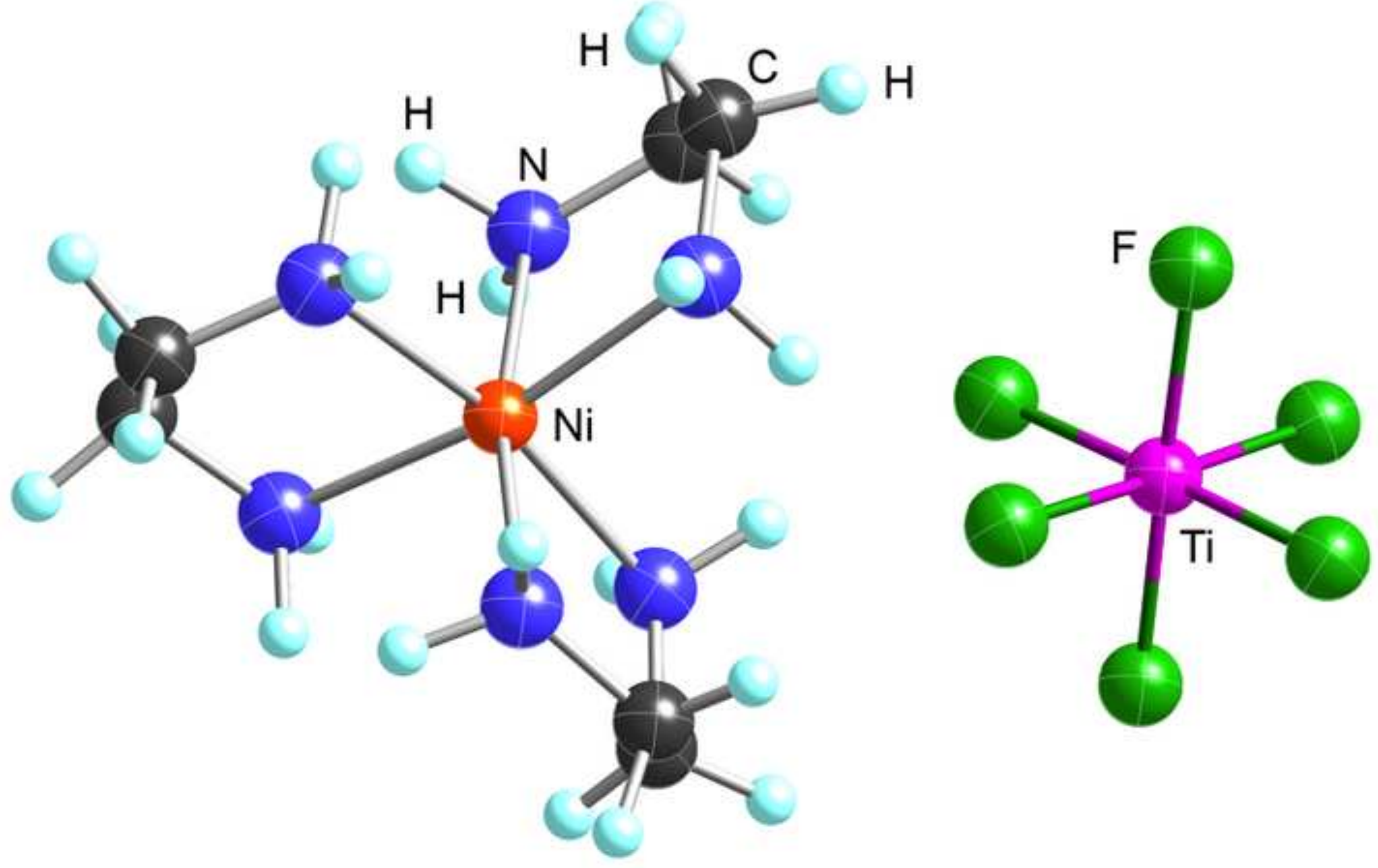


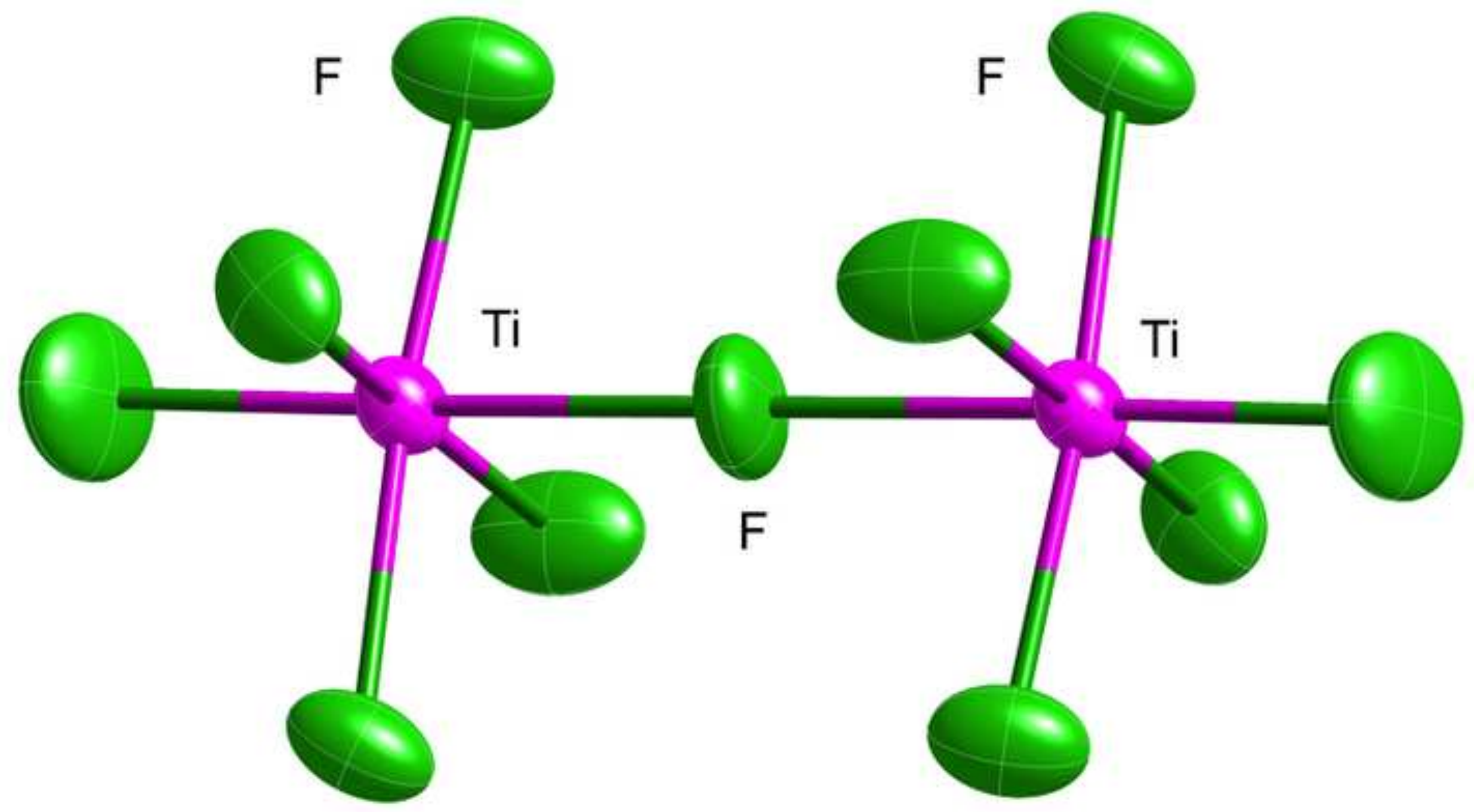




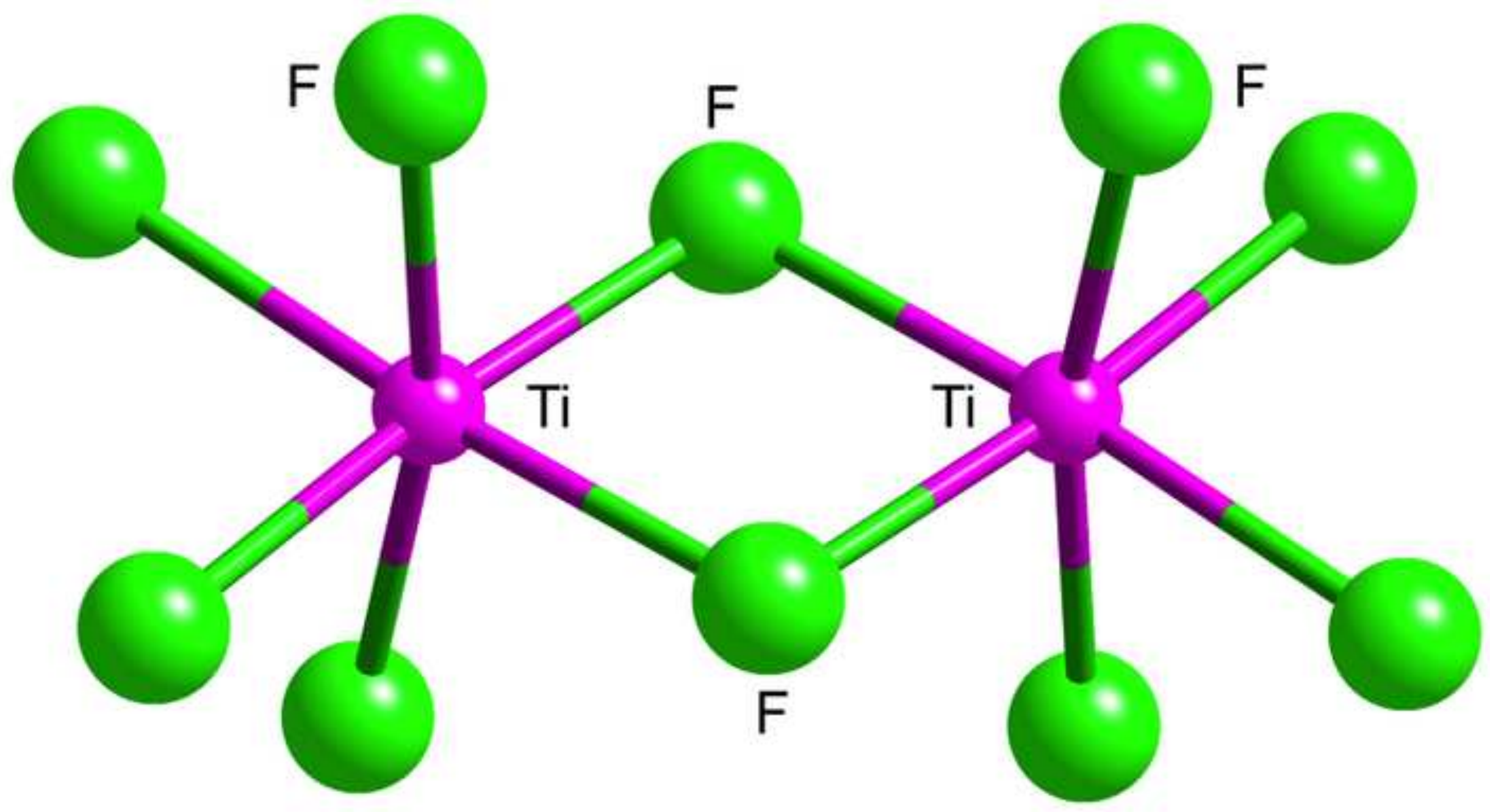


Click here to download high resolution image

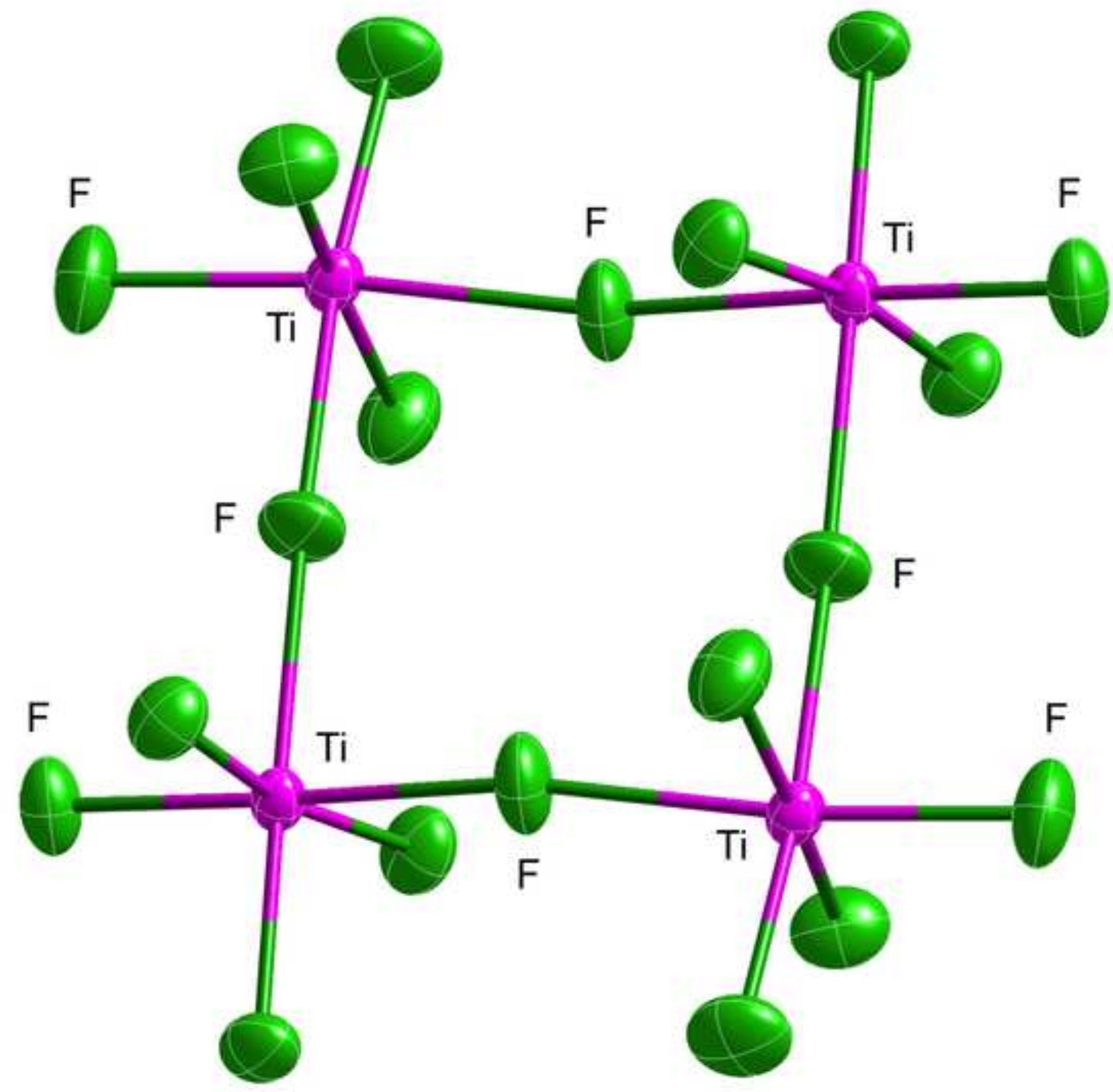




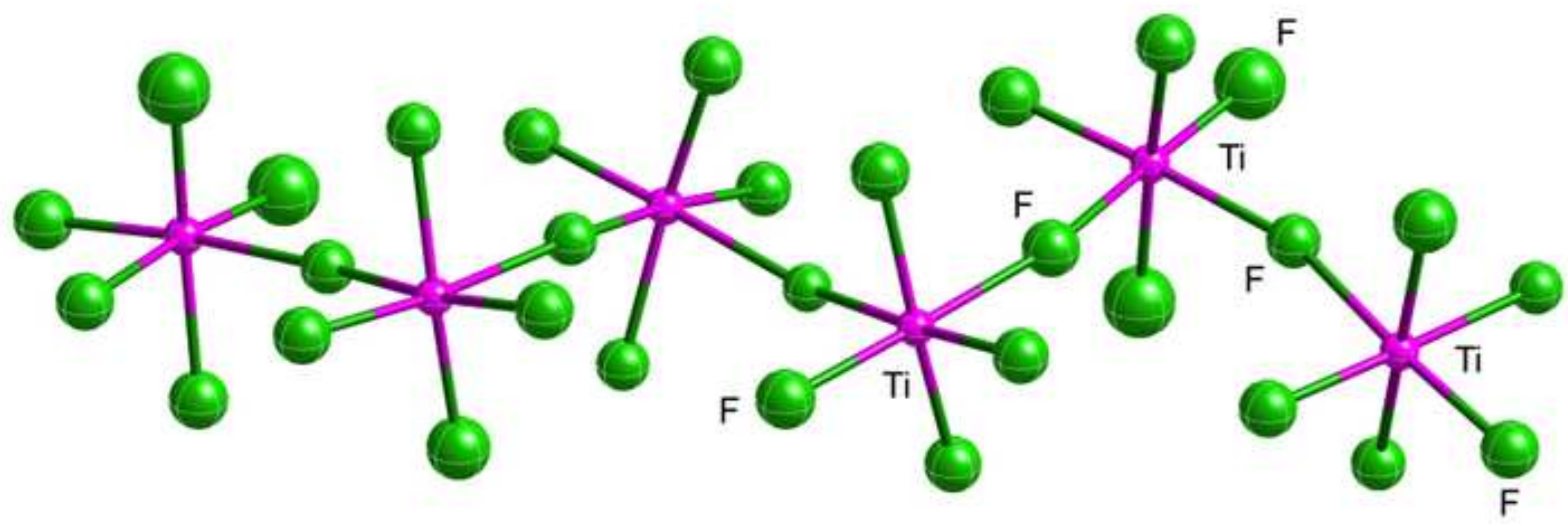


Figures)

Click here to download high resolution image

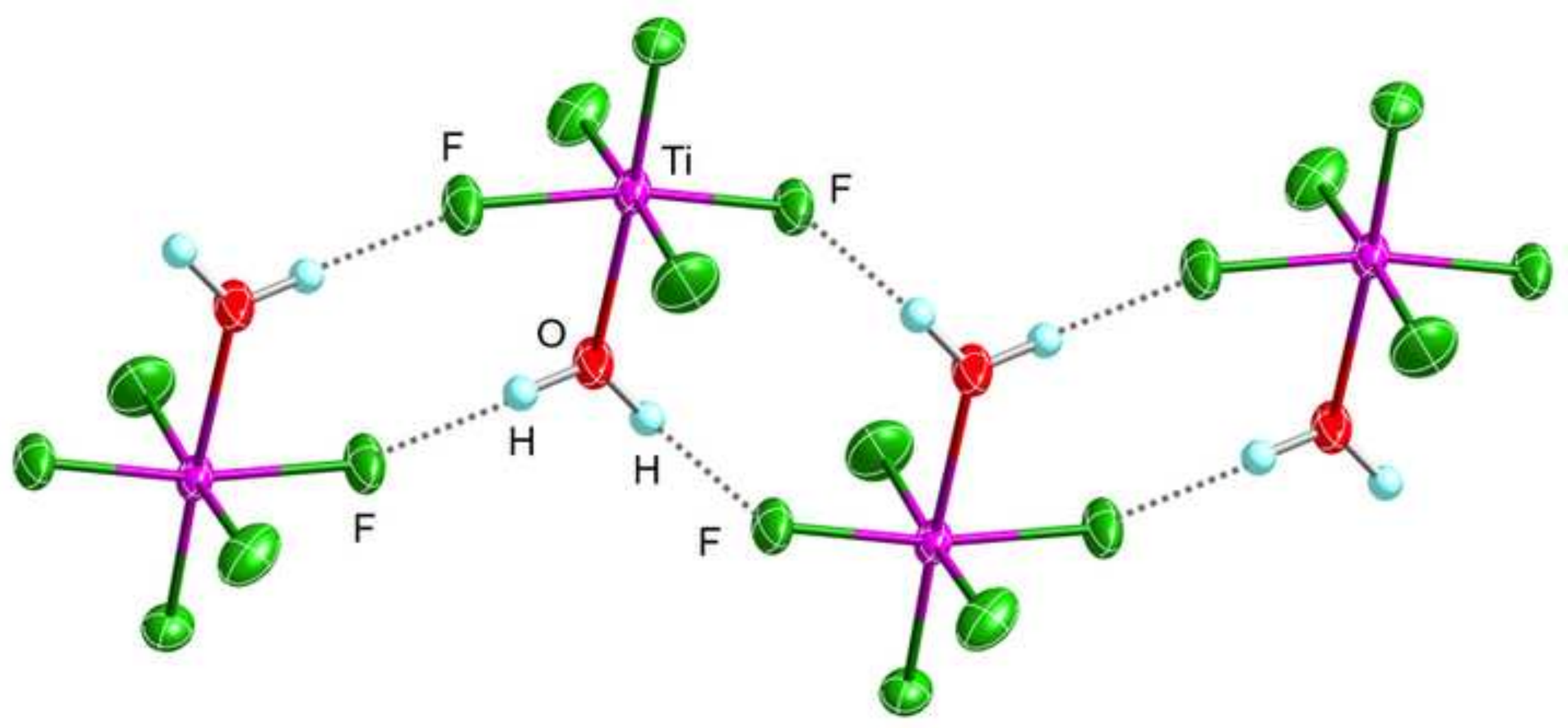




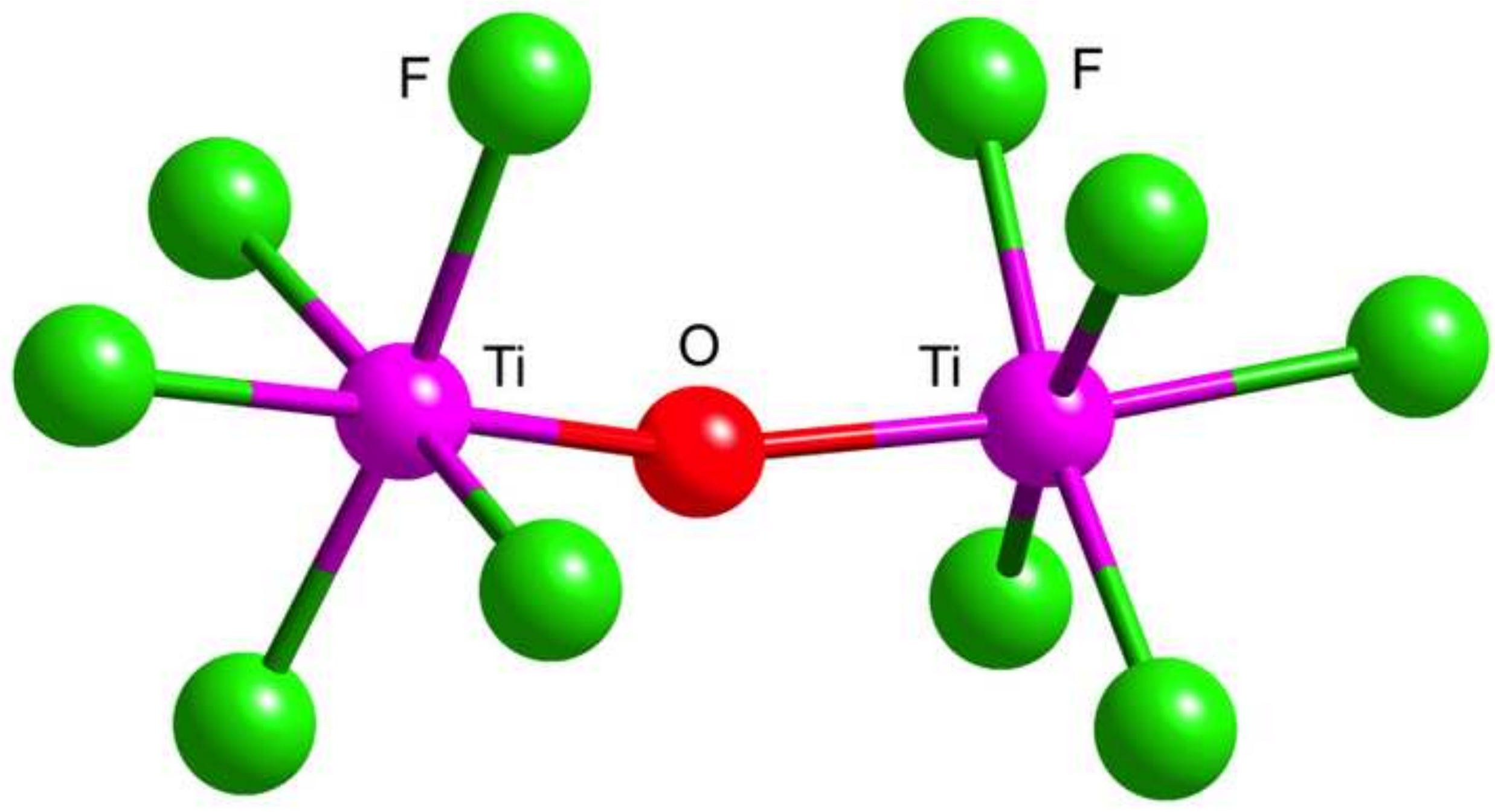




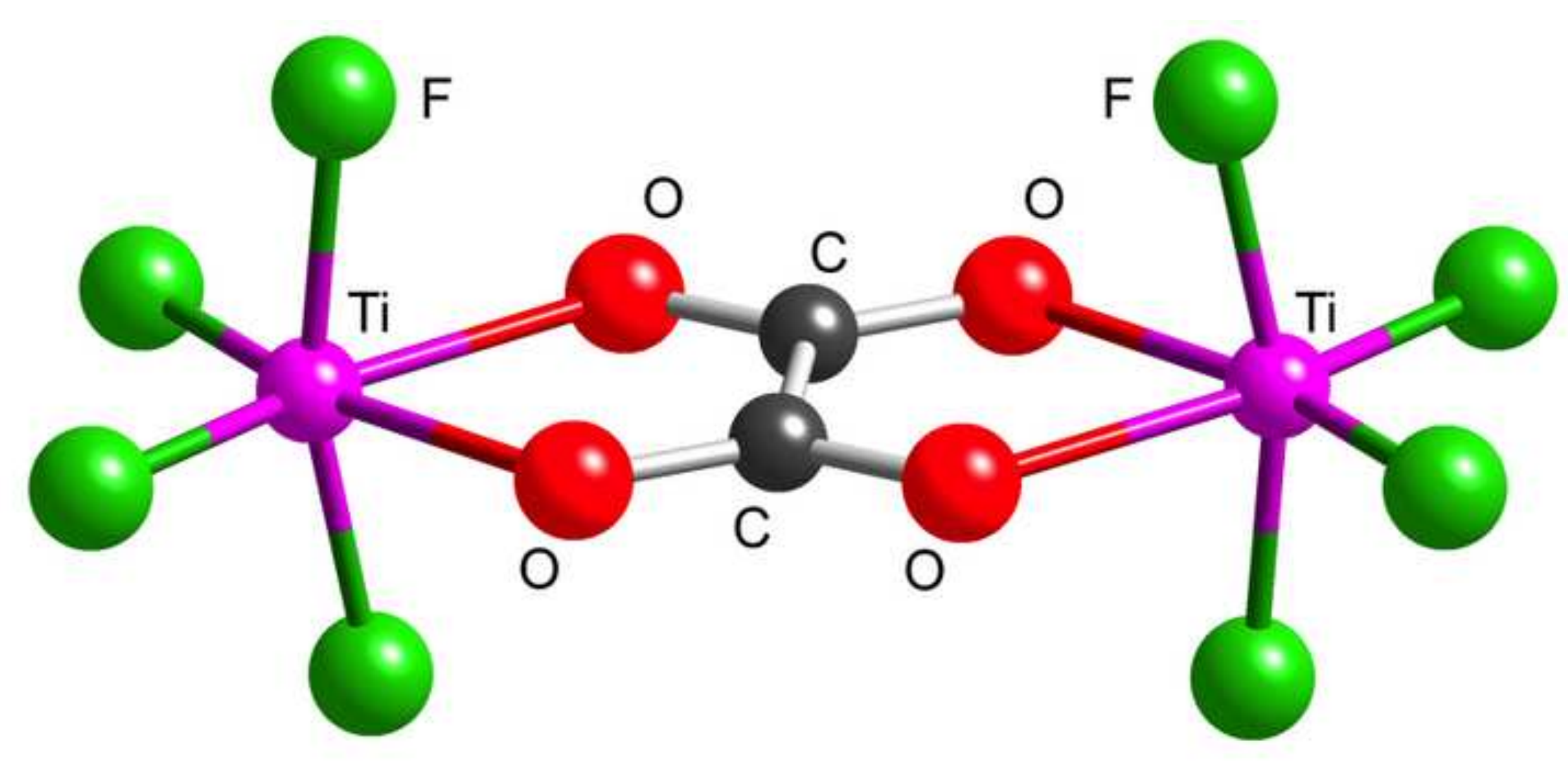

click here to download high resolution image 


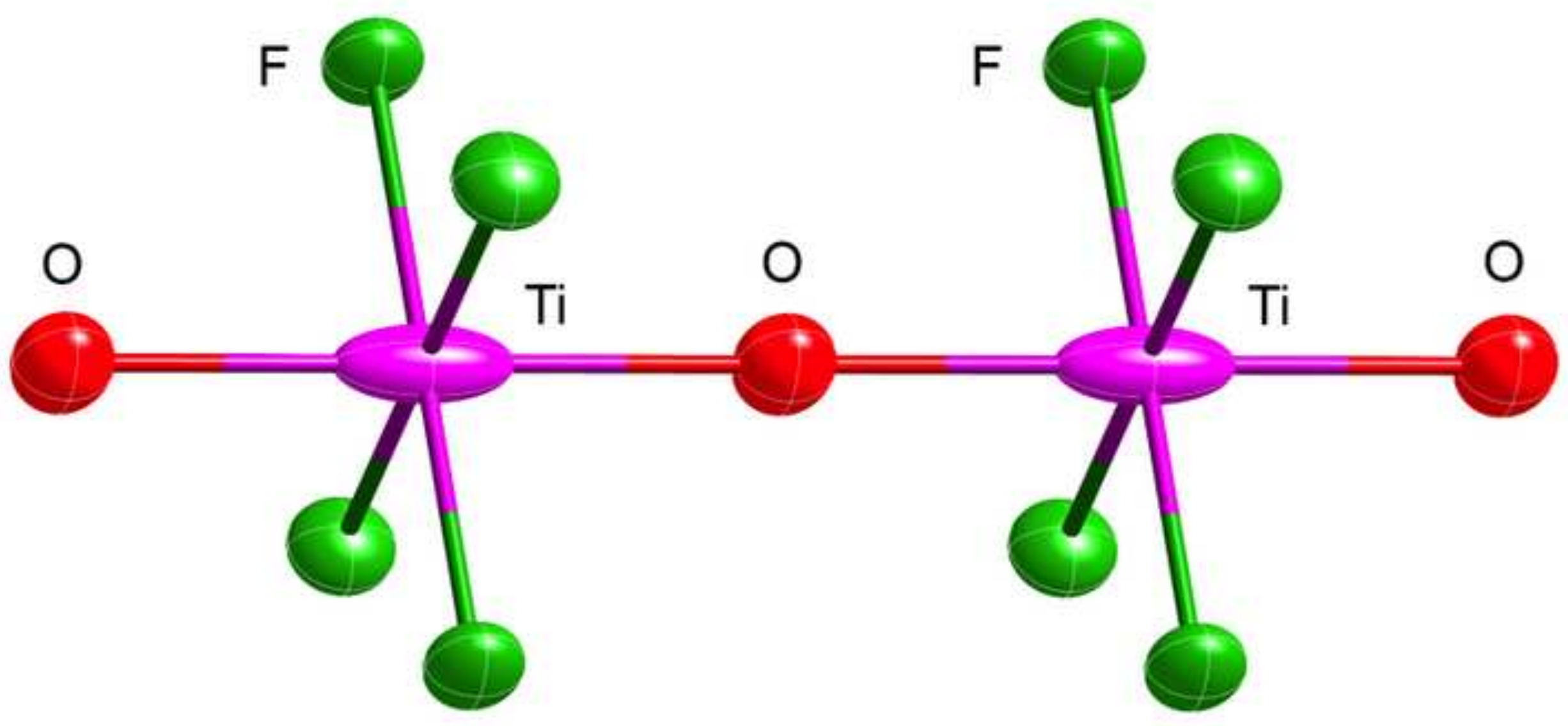


Click here to download high resolution image
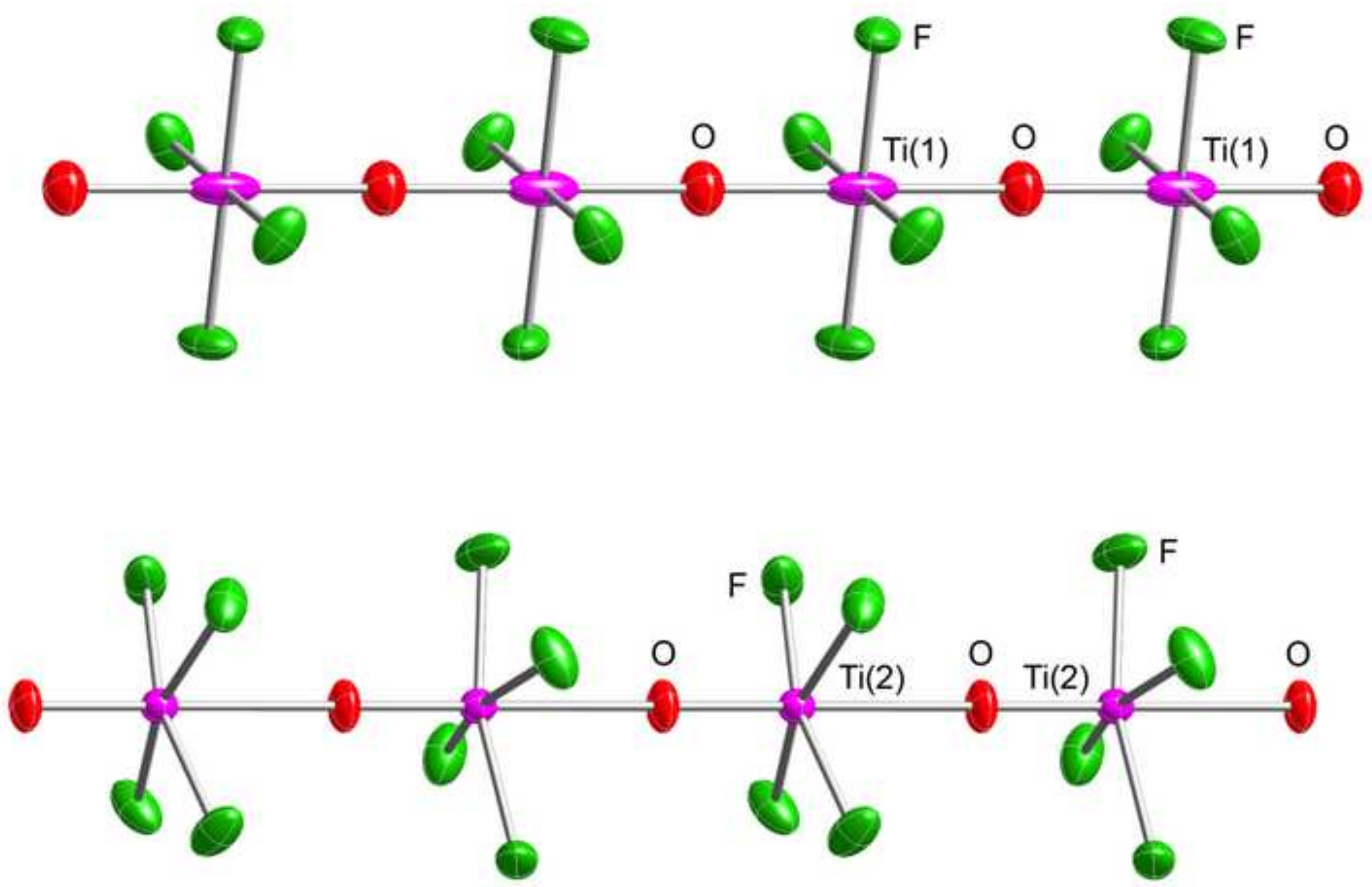
Click here to download high resolution image

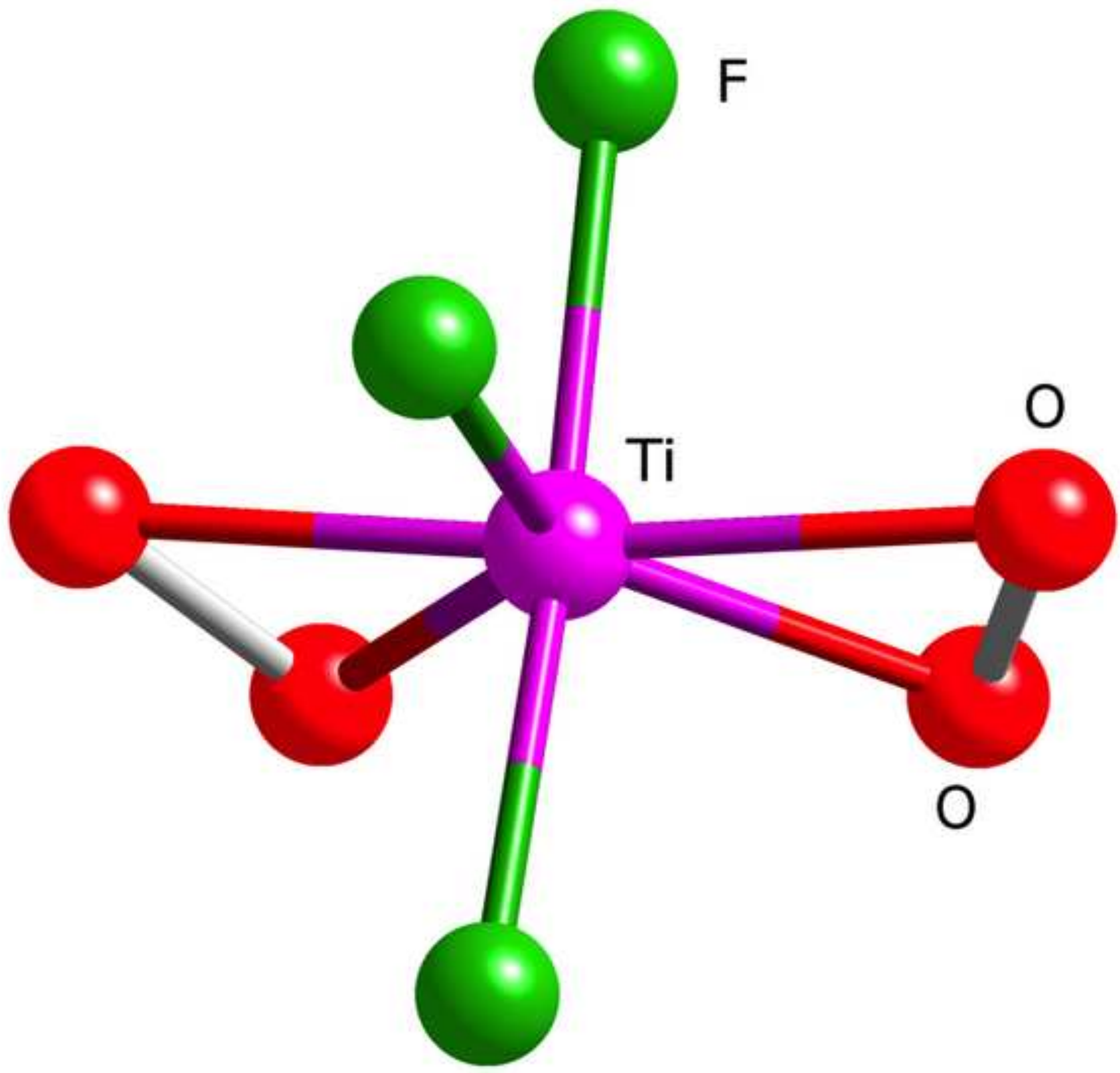




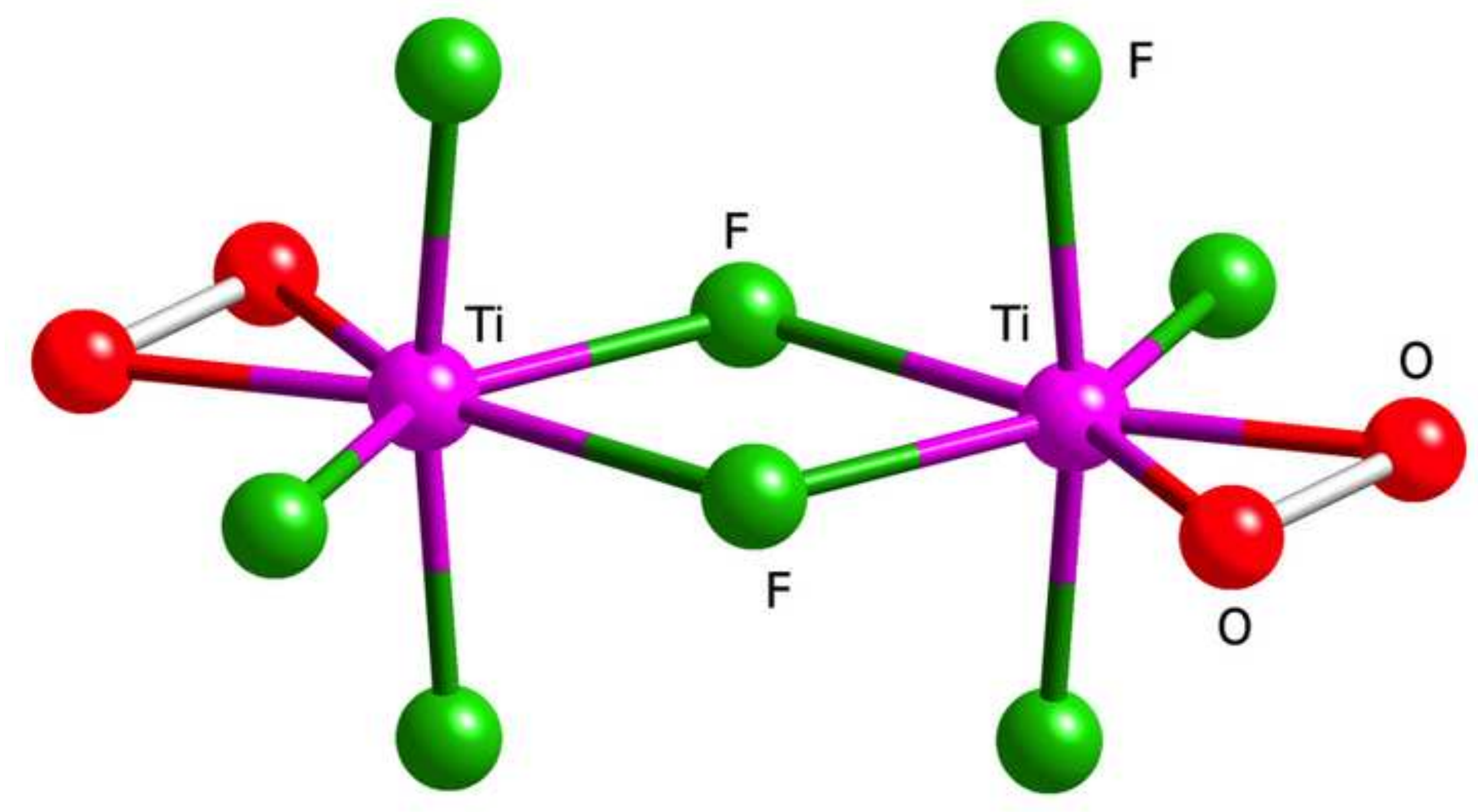


:

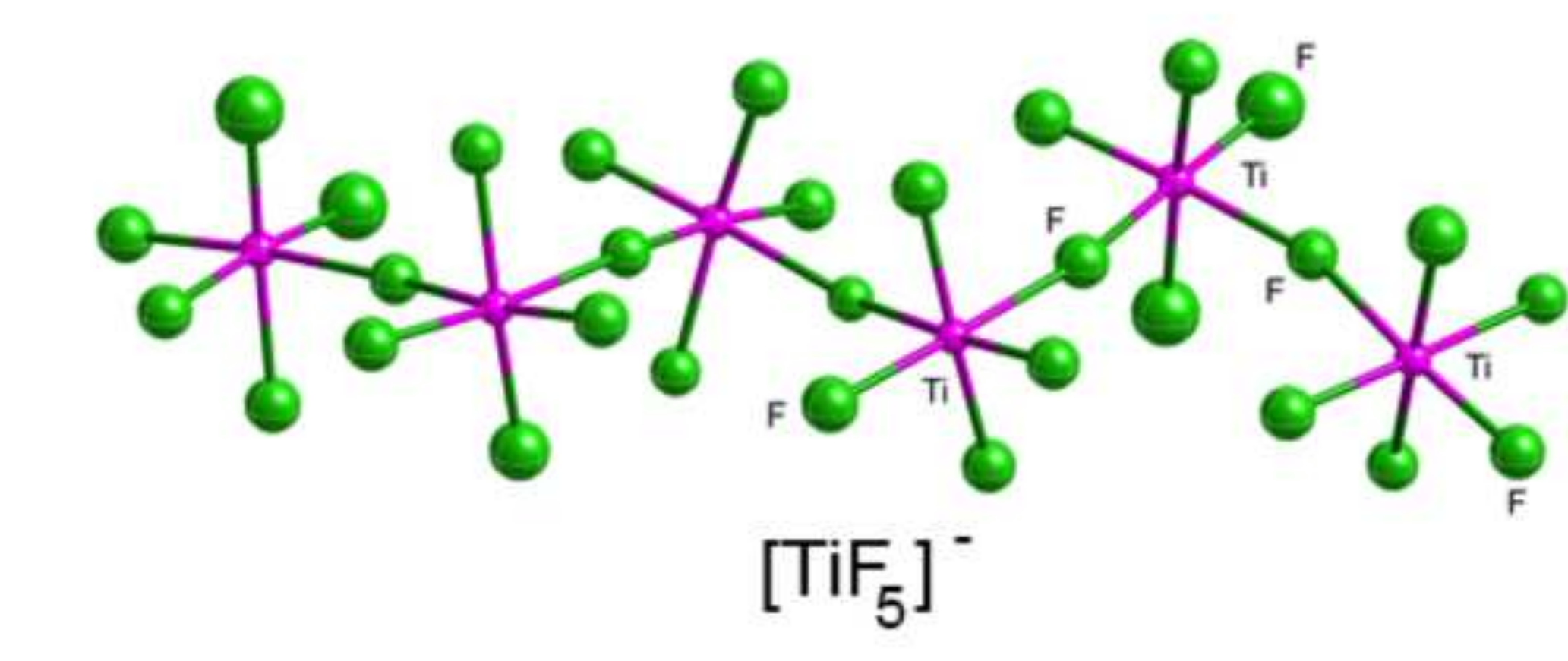


Structurally investigated fluoride and oxofluoride complexes of titanium(IV) and the intervals of Ti-F and Ti-O bond lengths

\begin{tabular}{|c|c|c|c|}
\hline & Compound & $\underline{R} \underline{\prime} R_{b}, \AA^{*}$ & References \\
\hline \multicolumn{4}{|c|}{ Structures of fluoride complexes of titanium(IV) } \\
\hline \multicolumn{4}{|c|}{ Hexafluoridotitanic(IV) acids } \\
\hline 1 & $\begin{array}{l}\mathrm{H}_{2} \mathrm{TiF}_{6} \cdot 2 \mathrm{H}_{2} \mathrm{O} \\
\left(\mathrm{H}_{3} \mathrm{O}\right)_{2}\left[\mathrm{TiF}_{6}\right]\end{array}$ & $1.86(1) \times 6$ & {$[12]$} \\
\hline 2 & $\begin{array}{l}\mathrm{H}_{2} \mathrm{TiF}_{6} \cdot 3 \mathrm{H}_{2} \mathrm{O} \\
\left(\mathrm{H}_{3} \mathrm{O}\right)\left(\mathrm{H}_{5} \mathrm{O}_{2}\right)\left[\mathrm{TiF}_{6}\right]\end{array}$ & $1.800-1.903$ & [13] \\
\hline 3 & $\begin{array}{l}\mathrm{H}_{2} \mathrm{TiF}_{6} \cdot 6 \mathrm{H}_{2} \mathrm{O} \\
\left(\mathrm{H}_{5} \mathrm{O}_{2}\right)_{2}\left[\mathrm{TiF}_{6}\right] \cdot 2 \mathrm{H}_{2} \mathrm{O}\end{array}$ & $1.837-1.877$ & [13] \\
\hline \multicolumn{4}{|c|}{ Alkali metal and ammonium hexafluoridotitanates(IV) } \\
\hline 4 & $\mathrm{~K}_{2}\left[\mathrm{TiF}_{6}\right]$ & $1.91 \times 6$ & [14] \\
\hline 5 & $\mathrm{~K}_{2}\left[\mathrm{TiF}_{6}\right]$ & $1.8605(6) \times 6$ & [15] \\
\hline 6 & $\mathrm{~K}_{2}(\mathrm{HF})\left[\mathrm{TiF}_{6}\right]$ & $1.842(3)-1.884(4)$ & [16] \\
\hline 7 & $\mathrm{Cs}_{2}\left[\mathrm{TiF}_{6}\right]$ & $1.868(2) \times 6$ & {$[17]$} \\
\hline 8 & $\left(\mathrm{NH}_{4}\right)_{2}\left[\mathrm{TiF}_{6}\right] 293 \mathrm{~K}$ & $1.864(1) \times 6$ & [18] \\
\hline 9 & $\left(\mathrm{NH}_{4}\right)_{2}\left[\mathrm{TiF}_{6}\right] 153 \mathrm{~K}$ & $1.857(1) \times 6$ & [18] \\
\hline 10 & $\mathrm{Tl}_{2}\left[\mathrm{TiF}_{6}\right]$ & $1.91 \times 6$ & [19] \\
\hline 11 & $\mathrm{Li}_{2}\left[\mathrm{TiF}_{6}\right]$ & & {$[20]$} \\
\hline 12 & $\mathrm{Li}_{2}\left[\mathrm{TiF}_{6}\right] \cdot 2 \mathrm{H}_{2} \mathrm{O}$ & \begin{tabular}{|l}
$1.903(3) \times 4$ \\
$1.968(4) \times 2$ \\
\end{tabular} & [21] \\
\hline 13 & $\begin{array}{ll}\mathrm{Na}_{2}\left[\mathrm{TiF}_{6}\right] & \mathrm{Ti}(1), \\
\mathrm{Ti}(2) & \\
\end{array}$ & $\begin{array}{l}1.70(1) \times 6 \\
1.75(1) \times 6\end{array}$ & [22] \\
\hline \multicolumn{4}{|c|}{ Hexafluoridotitanates(IV) with mixed monovalent cations } \\
\hline 14 & $\mathrm{NaRb}\left[\mathrm{TiF}_{6}\right]$ & $1.842(8)-1.868(7)$ & [23] \\
\hline 15 & $\mathrm{NaCs}\left[\mathrm{TiF}_{6}\right]$ & $1.848(3)-1.884(4)$ & [23] \\
\hline 16 & $\mathrm{Na}\left(\mathrm{NH}_{4}\right)\left[\mathrm{TiF}_{6}\right]$ & $1.837(2)-1.881(2)$ & [24] \\
\hline 17 & $\mathrm{Li}\left(\mathrm{NH}_{4}\right)\left[\mathrm{TiF}_{6}\right]$ & $1.822(1)-1.874(1)$ & [25] \\
\hline 18 & LiCs $\left[\mathrm{TiF}_{6}\right]$ & $1.825(4)-1.873(3)$ & [17] \\
\hline 19 & $\mathrm{LiNa}_{3}\left(\mathrm{TiF}_{6}\right)_{2}$ & $1.833(4)-1.892(4)$ & [26] \\
\hline \multicolumn{4}{|c|}{ Hexafluoridotitanates(IV) with derivative ammonium cations } \\
\hline 20 & {$\left[\mathrm{~N}\left(\mathrm{CH}_{3}\right)_{4}\right]_{2}\left[\mathrm{TiF}_{6}\right]$} & $1.8559(14) \times 6$ & [27] \\
\hline 21 & {$\left[\mathrm{~N}\left(\mathrm{CH}_{3}\right)_{4}\right]_{2}\left[\mathrm{TiF}_{6}\right]$} & $1.8493(18) \times 6$ & [28] \\
\hline 22 & {$\left[\mathrm{~N}\left(\mathrm{CH}_{3}\right)_{4}\right]_{2}\left[\mathrm{TiF}_{6}\right]$} & $1.8559(14) \times 6$ & [29] \\
\hline 23 & $\begin{array}{l}\left(\mathrm{NMe}_{4}\right)\left[\mathrm{Ti}(2)\left(\mathrm{H}_{2} \mathrm{O}\right)_{4} \mathrm{~F}_{2}\right] \\
{\left[\mathrm{Ti}(1) \mathrm{F}_{6}\right] \cdot \mathrm{H}_{2} \mathrm{O}}\end{array}$ & $1.716(3)-1.799(3)$ & [30] \\
\hline 24 & $\left(\mathrm{NH}_{3} \mathrm{OH}\right)_{2}\left[\mathrm{TiF}_{6}\right] \cdot 2 \mathrm{H}_{2} \mathrm{O}$ & $1.8384(7)-1.8460(7)$ & [31] \\
\hline 25 & $\begin{array}{l}{\left[\mathrm{N}\left(n-\mathrm{C}_{16} \mathrm{H}_{33}\right) \mathrm{Me}_{3}\right]_{2}} \\
{\left[\mathrm{TiF}_{6}\right] \cdot 2 \mathrm{H}_{2} \mathrm{O}}\end{array}$ & $1.836(1)-1.850(1)$ & {$[32]$} \\
\hline
\end{tabular}




\begin{tabular}{|c|c|c|c|}
\hline 26 & $\left(\mathrm{enH}_{2}\right)\left[\mathrm{TiF}_{6}\right]$ & $1.848-1.859$ & [33] \\
\hline 27 & $\begin{array}{l}\left.\mathrm{N}_{2} \mathrm{H}_{5}\right)_{2}\left[\mathrm{TiF}_{6}\right] \\
\mathrm{Ti}(1) \\
\mathrm{Ti}(2)\end{array}$ & $\begin{array}{l}1.831(3)-1.925(2) \\
1.825(3)-1.885(2)\end{array}$ & [35] \\
\hline 28 & $\left(\mathrm{~N}_{2} \mathrm{H}_{6}\right)\left[\mathrm{TiF}_{6}\right]$ & $1.855(4) \times 6$ & [36] \\
\hline \multicolumn{4}{|c|}{ Hybrid organic-inorganic hexafluoridotitanates(IV) } \\
\hline 29 & {$\left[\mathrm{C}\left(\mathrm{NH}_{2}\right)_{3}\right]_{2}\left[\mathrm{TiF}_{6}\right]$} & $1.809(1)-1.904(1)$ & [37] \\
\hline 30 & {$\left[\mathrm{C}\left(\mathrm{NH}_{2}\right)_{3}\right]_{2}\left[\mathrm{TiF}_{6}\right]$} & $1.814(7)-1.904(16)$ & [28] \\
\hline 31 & $\left(\mathrm{C}_{5} \mathrm{H}_{5} \mathrm{NH}\right)_{2}\left[\mathrm{TiF}_{6}\right] \cdot \mathrm{H}_{2} \mathrm{O}$ & $1.8194(13)-1.8976(12)$ & [38] \\
\hline 32 & $\left(\mathrm{C}_{6} \mathrm{H}_{7} \mathrm{NH}\right)_{2}\left[\mathrm{TiF}_{6}\right] \cdot 2 \mathrm{H}_{2} \mathrm{O}$ & $1.8420(10)-1.8633(9)$ & [38] \\
\hline 33 & $\left(\mathrm{C}_{7} \mathrm{H}_{9} \mathrm{NH}\right)_{2}\left[\mathrm{TiF}_{6}\right]$ & $1.8388(15)-1.8628(16)$ & [38] \\
\hline 34 & $\left(\mathrm{C}_{8} \mathrm{H}_{11} \mathrm{NH}\right)_{2}\left[\mathrm{TiF}_{6}\right]$ & $1.808(2)-1.8748(15)$ & [38] \\
\hline 35 & $\begin{array}{l}\left(\mathrm{C}_{6} \mathrm{H}_{12} \mathrm{~N}_{2} \mathrm{H}_{2}\right)\left[\mathrm{TiF}_{6}\right] \cdot \mathrm{H}_{2} \mathrm{O} \\
\left(\left(\mathrm{dabcoH}_{2}\right)\left[\mathrm{TiF}_{6}\right] \cdot \mathrm{H}_{2} \mathrm{O}\right) \\
\operatorname{Ti}(1) \\
\operatorname{Ti}(2)\end{array}$ & $\begin{array}{l}1.8462(17)-1.8680(16) \\
1.8402(17)-1.8841(16)\end{array}$ & [39] \\
\hline 36 & $(\mathrm{phenH})_{2}\left[\mathrm{TiF}_{6}\right]$ & $1.8443(9)-1.8788(7)$ & [40] \\
\hline 37 & $\begin{array}{l}\left(\mathrm{C}_{3} \mathrm{H}_{4} \mathrm{~N}_{2} \mathrm{H}\right)_{2}\left[\mathrm{TiF}_{6}\right] \cdot 2 \mathrm{HF} \\
\left((\mathrm{ImH})_{2}\left[\mathrm{TiF}_{6}\right] \cdot 2 \mathrm{HF}\right)\end{array}$ & 1.811(4)-1.908(4) & [41] \\
\hline 38 & $\left(\mathrm{Ph}_{4} \mathrm{P}\right)_{2}\left[\mathrm{TiF}_{6}\right] \cdot \mathrm{MeCN}$ & $1.8567(14)-1.8671(13)$ & [42] \\
\hline \multicolumn{4}{|c|}{ Divalent metal hexafluoridotitanates(IV) } \\
\hline 39 & {$\left[\mathrm{Mn}\left(\mathrm{H}_{2} \mathrm{O}\right)_{6}\right]\left[\mathrm{TiF}_{6}\right]$} & $1.823(1) \times 6$ & [43] \\
\hline 40 & {$\left[\mathrm{Zn}\left(\mathrm{H}_{2} \mathrm{O}\right)_{6}\right]\left[\mathrm{TiF}_{6}\right]$} & $1.829(1) \times 6$ & [43] \\
\hline 41 & {$\left[\mathrm{Zn}\left(\mathrm{H}_{2} \mathrm{O}\right)_{6}\right]\left[\mathrm{TiF}_{6}\right]$} & $1.779(6)-1.801(6)$ & [44] \\
\hline 42 & {$\left[\mathrm{Ni}\left(\mathrm{H}_{2} \mathrm{O}\right)_{6}\right]\left[\mathrm{TiF}_{6}\right]$} & $1.796(5) \times 6$ & [45] \\
\hline 43 & $\begin{array}{l}{\left[\mathrm{Ni}\left(\mathrm{H}_{2} \mathrm{O}\right)_{6}\right]\left[\mathrm{TiF}_{6}\right] \cdot(\mathrm{hmta})_{2}} \\
\cdot \mathrm{H}_{2} \mathrm{O}\end{array}$ & $1.8105(8)-1.8917(8)$ & [46] \\
\hline 44 & {$\left[\mathrm{Cu}\left(\mathrm{H}_{2} \mathrm{O}\right)_{4}\right]\left[\mathrm{TiF}_{6}\right]$} & $1.86(3)-1.88(3)$ & [47] \\
\hline 45 & $\mathrm{SrTiF}_{6} \cdot 2 \mathrm{H}_{2} \mathrm{O} \quad 297 \mathrm{~K}$ & $1.84(1)-1.88(1)$ & [48] \\
\hline 46 & $\mathrm{SrTiF}_{6} \cdot 2 \mathrm{H}_{2} \mathrm{O} \quad 173 \mathrm{~K}$ & $1.84(1)-1.88(1)$ & [49] \\
\hline 47 & {$\left[\mathrm{Sn}_{6} \mathrm{~F}_{10}\right]\left[\mathrm{TiF}_{6}\right]$} & $1.812(3)-1.838(4)$ & [50] \\
\hline 48 & {$\left[\mathrm{Tl}_{5} \mathrm{~F}_{3}\right]\left[\mathrm{TiF}_{6}\right]$} & $\begin{array}{l}1.86(1) \times 4, \\
1.87(1) \times 2\end{array}$ & [51] \\
\hline \multicolumn{4}{|c|}{ Double fluoride complexes of titanium(IV) } \\
\hline 49 & $\mathrm{Na}_{2}\left[\mathrm{TiF}_{6}\right] \cdot \mathrm{NaHF}_{2}$ & $1.867(8)-1.900(8)$ & [52] \\
\hline 50 & {$\left[\mathrm{Cu}\left(\mathrm{H}_{2} \mathrm{O}\right)_{4}\right]\left[\mathrm{TiF}_{6}\right] \cdot \mathrm{NH}_{4} \mathrm{~F}$} & $1.838(20)-1.919(25)$ & [53] \\
\hline 51 & $\left(\mathrm{~N}_{2} \mathrm{H}_{6}\right)\left[\mathrm{TiF}_{6}\right] \cdot\left(\mathrm{N}_{2} \mathrm{H}_{6}\right) \mathrm{F}_{2}$ & $1.851(1)-1.867(6)$ & [54] \\
\hline \multicolumn{4}{|c|}{ Hexafluoridotitanates(IV) with hybrid divalent and trivalent metal cations } \\
\hline 52 & {$\left[\mathrm{Ni}(\mathrm{en})_{3}\right]\left[\mathrm{TiF}_{6}\right]$} & $1.823(4) \times 6$ & [55] \\
\hline 53 & {$\left[\mathrm{Cu}(\mathrm{en})_{2}\right]\left[\mathrm{TiF}_{6}\right]$} & $1.746(5)-1.879(8)$ & [55] \\
\hline 54 & $(\mathrm{pyH})_{2}\left\{\mathrm{Cu}(\mathrm{py})_{4}\left(\mathrm{TiF}_{6}\right)_{2}\right\}$ & $1.813(5)-1.899(4)$ & [55] \\
\hline 55 & {$\left[\mathrm{Cu}(\mathrm{py})_{4}\right]\left[\mathrm{TiF}_{6}\right] \cdot 3 \mathrm{H}_{2} \mathrm{O}$} & $1.86(1)-1.87(1)$ & [56] \\
\hline 56 & {$\left[\mathrm{Cu}(\mathrm{pyz})\left(\mathrm{H}_{2} \mathrm{O}\right)_{2}\right]\left[\mathrm{TiF}_{6}\right]$} & $1.844(2)-1.870(2)$ & [57] \\
\hline
\end{tabular}




\begin{tabular}{|c|c|c|c|}
\hline 57 & $\begin{array}{l}{\left[\mathrm{Cu}\left(4,4^{\prime}-\right.\right.} \\
\left.\text { bipy })_{2}\left(\mathrm{H}_{2} \mathrm{O}\right)_{2}\right]\left[\mathrm{TiF}_{6}\right]\end{array}$ & $1.824(6)-1.860(6)$ & [58] \\
\hline 58 & {$\left[\mathrm{Cu}\left(4,4^{\prime} \text {-bipy }\right)_{2}\right]\left[\mathrm{TiF}_{6}\right]$} & $1.858(15)-1.865(10)$ & [59] \\
\hline 59 & $\begin{array}{l}{\left[\mathrm{Co}\left(\mathrm{DH}_{2}\right)(\mathrm{D})(\mathrm{tu})_{2}\right]_{2}\left[\mathrm{TiF}_{6}\right]} \\
\cdot 2 \mathrm{dmf}\end{array}$ & $1.841(2)-1.871(2)$ & [60] \\
\hline 60 & $\begin{array}{l}{\left[\mathrm{Co}\left(\mathrm{NioxH}_{2}\right)_{2}(\mathrm{tu})_{2}\right]_{2}\left[\mathrm{TiF}_{6}\right]} \\
\cdot 2.25 \mathrm{H}_{2} \mathrm{O}\end{array}$ & $1.829(7)-1.870(4)$ & [60] \\
\hline 61 & $\begin{array}{l}\left.\mid \mathrm{Co}(\mathrm{DfgH})_{2}(\mathrm{tu})_{2}\right]_{2}\left[\mathrm{TiF}_{6}\right] \\
\cdot 4 \mathrm{dmf} \cdot 1.5 \mathrm{H}_{2} \mathrm{O}\end{array}$ & $1.812(5)-1.898(4)$ & [60] \\
\hline 62 & $\begin{array}{l}{\left[\mathrm{Co}(\mathrm{DH})_{2}(\mathrm{seu})_{1.75}\right.} \\
\left.(\mathrm{Se}-\mathrm{seu})_{0.25}\right]_{2}\left[\mathrm{TiF}_{6}\right] \cdot \mathrm{H}_{2} \mathrm{O} \\
\mathrm{Ti}(1) \\
\mathrm{Ti}(2)\end{array}$ & $\begin{array}{l}1.73(2)-1.97(3) \\
1.80(2)-1.82(2)\end{array}$ & [61] \\
\hline 63 & $\begin{array}{l}{\left[\mathrm{Co}(\mathrm{DH})_{2}(\mathrm{tu})_{2}\right]\left[\mathrm{Rh}(\mathrm{tu})_{6}\right]} \\
{\left[\mathrm{TiF}_{6}\right]_{2} \cdot 2 \mathrm{H}_{2} \mathrm{O}}\end{array}$ & $1.816(7)-1.906(4)$ & [62] \\
\hline 64 & $\begin{array}{l}{\left[\mathrm{Co}(\mathrm{NioxH})_{2}(\mathrm{tu})_{2}\right]_{2}} \\
{\left[\mathrm{Rh}(\mathrm{tu})_{5} \mathrm{Cl}\right][\mathrm{TiF}]_{6}} \\
\cdot \mathrm{CH}_{3} \mathrm{OH} \cdot 3 \mathrm{H}_{2} \mathrm{O} \\
\mathrm{Ti}(1) \\
\mathrm{Ti}(2)\end{array}$ & $\begin{array}{l}1.830(6)-1.864(7) \\
1.823(6)-1.866(6)\end{array}$ & [62] \\
\hline \multicolumn{4}{|c|}{ Vertex-bridged dimeric fluoridotitanates(IV) } \\
\hline 65 & $\begin{array}{l}\left(\mathrm{C}_{5} \mathrm{H}_{5} \mathrm{NH}\right)_{2}\left(\mathrm{H}_{3} \mathrm{O}\right)\left[\mathrm{Ti}_{2} \mathrm{~F}_{11}\right] \\
\cdot \mathrm{H}_{2} \mathrm{O}\end{array}$ & $\frac{1.776(2)-1.880(2)}{1.9732(10)}$ & [63] \\
\hline 66 & $\begin{array}{l}\left(\mathrm{NMe}_{4}\right)_{4}\left[\mathrm{Ti}(1)_{2} \mathrm{~F}_{11}\right] \\
{\left[\mathrm{Ti}(2) \mathrm{F}_{9}\left(\mathrm{H}_{2} \mathrm{O}\right)_{2}\right]} \\
\operatorname{Ti}(1)\end{array}$ & $\frac{1.811(2)-1.903(3)}{1.9927(1)}$ & [64] \\
\hline 67 & $\begin{array}{l}(\operatorname{ImH})_{3}\left[\mathrm{Ti}_{2} \mathrm{~F}_{11}\right] \\
\operatorname{Ti}(1) \\
\operatorname{Ti}(2) \\
\operatorname{Ti}(3)\end{array}$ & \begin{tabular}{|l}
$1.796(3)-1.857(2)$ \\
$1.9805(6)$ \\
$1.792(2)-1.862(2)$ \\
$1.9683(5)$ \\
$1.768(3)-1.908(2)$ \\
$1.9770(8)$ \\
\end{tabular} & [41] \\
\hline \multicolumn{4}{|c|}{ Edge-bridged dimeric fluoridotitanates(IV) } \\
\hline 68 & \begin{tabular}{|l}
$\left(\mathrm{C}_{10} \mathrm{H}_{12} \mathrm{~S}_{4}\right)_{3}\left[\mathrm{Ti}_{2} \mathrm{~F}_{10}\right]$ \\
$\left((\mathrm{TMTTF})_{3}\left[\mathrm{Ti}_{2} \mathrm{~F}_{10}\right]\right)$
\end{tabular} & $\frac{1.781(3)-1.822(2)}{2.024(2)}$ & [65] \\
\hline 69 & $\begin{array}{l}\left(\mathrm{C}_{4} \mathrm{H}_{10} \mathrm{~N}_{2} \mathrm{H}_{2}\right)\left[\mathrm{Ti}_{2} \mathrm{~F}_{10}\right] \\
-2 \mathrm{H}_{2} \mathrm{O}\end{array}$ & $\frac{1.8975(16)-1.9485(15)}{1.8587(16), 1.8758(16)}$ & {$[66]$} \\
\hline \multicolumn{4}{|c|}{$\begin{array}{l}\text { Fluoride complexes of Ti(IV) with tetrameric, pentameric, and octameric } \\
\text { anions }\end{array}$} \\
\hline 70 & $\begin{array}{l}{\left[\mathrm{TiF}_{2}([15] \text { crown-5)] }\right.} \\
{\left[\mathrm{Ti}_{4} \mathrm{~F}_{18}\right] \cdot 0.5 \mathrm{MeCN}}\end{array}$ & $\frac{1.754(3)-1.777(3)}{1.965(3)-2.010(3)}$ & {$[67]$} \\
\hline 71 & $\left(\mathrm{NMe}_{4}\right)_{2}\left[\mathrm{Ti}_{4} \mathrm{~F}_{18}\right]$ & $\frac{1.758(4)-176.8(4)}{1.975(4)-2.003(4)}$ & [68] \\
\hline
\end{tabular}




\begin{tabular}{|c|c|c|c|}
\hline 72 & $\left(\mathrm{Ph}_{4} \mathrm{P}\right)_{2}\left[\mathrm{Ti}_{4} \mathrm{~F}_{18}\right]$ & $\frac{1.752(4)-1.783(4)}{1.959(4)-2.019(4)}$ & {$[68]$} \\
\hline 73 & {$\left[\mathrm{o}-\mathrm{C}_{6} \mathrm{H}_{4}\left(\mathrm{PPh}_{2} \mathrm{H}\right)_{2}\right]\left[\mathrm{Ti}_{4} \mathrm{~F}_{18}\right]$} & $\frac{1.753(4)-1.790(4)}{1.966(4)-2.016(4)}$ & [69] \\
\hline 74 & {$\left[\mathrm{XeF}_{5}\right]_{3}\left[\mathrm{Ti}_{4} \mathrm{~F}_{19}\right]$} & $\frac{1.747(5)-1.839(5)}{1.935(4)-2.044(4)}$ & {$[70]$} \\
\hline 75 & $\beta-(\operatorname{ImH})_{4}\left[\mathrm{Ti}_{4} \mathrm{~F}_{20}\right]$ & $\frac{1.776(3)-1.824(4)}{1.956(2)-1.978(2)}$ & {$[41]$} \\
\hline 76 & $\alpha-(\operatorname{ImH})_{4}\left[\mathrm{Ti}_{4} \mathrm{~F}_{20}\right]$ & $\frac{1.790(2)-1.840(2)}{1.965(2)-1.989(2)}$ & [41] \\
\hline 77 & $(\operatorname{ImH})_{3}\left[\mathrm{Ti}_{5} \mathrm{~F}_{23}\right]$ & $\frac{1.757(3)-1.848(3)}{1.942(2)-2.014(2)}$ & [41] \\
\hline 78 & $\mathrm{~K}_{4}\left[\mathrm{Ti}_{8} \mathrm{~F}_{36}\right] \cdot 8 \mathrm{HF}$ & $\frac{1.755(2)-1.801(2)}{1.924(2)-2.014(2)}$ & {$[71]$} \\
\hline 79 & $\mathrm{Rb}_{4}\left[\mathrm{Ti}_{8} \mathrm{~F}_{36}\right] \cdot 6 \mathrm{HF}$ & $\frac{1.754(6)-1.783(6)}{1.939(7)-2.005(6)}$ & {$[71]$} \\
\hline \multicolumn{4}{|c|}{ One-dimensional chain structures } \\
\hline 80 & $\left(\mathrm{H}_{3} \mathrm{O}\right) \mathrm{TiF}_{5}$ & $\frac{1.764(4)-1.835(5)}{1.961(3), 2.021(3)}$ & {$[72]$} \\
\hline 81 & $\begin{array}{l}\left(\mathrm{NH}_{4}\right) \mathrm{TiF}_{5} \\
\mathrm{Ti}(1) \\
\operatorname{Ti}(2) \\
\operatorname{Ti}(3) \\
\operatorname{Ti}(4)\end{array}$ & \begin{tabular}{|l|}
$1.779(2)-1.849(2)$ \\
$1.974(2), 1.988(2)$ \\
$1.778(2), 1.832(2)$ \\
$1.980(2), 1.995(2)$ \\
$1.777(2)-1.819(2)$ \\
$1.974(2), 1.997(2)$ \\
$1.762(2)-1.838(2)$ \\
$1.972(2), 1.975(2)$ \\
\end{tabular} & {$[73]$} \\
\hline \multicolumn{4}{|c|}{ Double chain structures } \\
\hline 82 & $\left(\mathrm{H}_{3} \mathrm{O}\right) \mathrm{Ti}_{2} \mathrm{~F}_{9}$ & $\frac{1.754(2)-1.803(3)}{1.966(3)-2.004(2)}$ & [68] \\
\hline 83 & $\mathrm{CsTi}_{2} \mathrm{~F}_{9}$ & $\frac{1.758(7)-1.790(7)}{1.955(3)-1.988(7)}$ & [68] \\
\hline 84 & $\beta-(\operatorname{ImH})\left[\mathrm{Ti}_{2} \mathrm{~F}_{9}\right]$ & $\frac{1.763(2)-1.772(3)}{1.9669(8)-1.979(2)}$ & [41] \\
\hline 85 & $\alpha-(\operatorname{ImH})\left[\mathrm{Ti}_{2} \mathrm{~F}_{9}\right]$ & $\frac{1.768(2)-1.787(2)}{1.963(1)-1.991(1)}$ & [41] \\
\hline \multicolumn{4}{|c|}{ Layered structure } \\
\hline 86 & \begin{tabular}{|l}
$\mathrm{CsTi}_{8} \mathrm{~F}_{33}$ \\
$\operatorname{Ti}(1)$ \\
$\operatorname{Ti}(2)$ \\
$\operatorname{Ti}(3)$ \\
$\operatorname{Ti}(4)$
\end{tabular} & $\begin{array}{l}1.733 \times 3,2.027 \times 3 \\
1.721-2.039 \\
1.710-2.003 \\
1.742 \times 3,2.059 \times 3\end{array}$ & [74] \\
\hline
\end{tabular}




\begin{tabular}{|c|c|c|c|}
\hline 87 & \begin{tabular}{|l}
$\left(\mathrm{O}_{2}\right)_{2} \mathrm{Ti}_{7} \mathrm{~F}_{30}$ \\
$\operatorname{Ti}(1)$ \\
$\operatorname{Ti}(2)$ \\
\end{tabular} & \begin{tabular}{|l}
$1.87(1) \times 6$ \\
$1.73(7)-2.09(5)$ \\
\end{tabular} & {$[75]$} \\
\hline 88 & $\begin{array}{l}\mathrm{TiF}_{4} \\
\mathrm{Ti}(1) \\
\\
\mathrm{Ti}(2) \\
\mathrm{Ti}(3)\end{array}$ & $\begin{array}{l}\frac{1.715-1.931}{1.961,1.978} \\
\frac{1.716-1.932}{1.965,1.975} \\
\frac{1.704-1.933}{1.974,1.978}\end{array}$ & [76] \\
\hline \multicolumn{4}{|c|}{ Structures of oxo- and hydroxyfluoride complexes of titanium(IV) } \\
\hline \multicolumn{4}{|c|}{ Oxofluoride complexes } \\
\hline 89 & $\mathrm{~K}_{2} \mathrm{NaTiOF}_{5}$ & $\mathrm{Ti}(\mathrm{O}, \mathrm{F}) 1.918 \times 6$ & [77] \\
\hline 90 & $\mathrm{Rb}_{2} \mathrm{KTiOF}_{5} \quad 297 \mathrm{~K}$ & $\begin{array}{l}\text { Ti-X(1)1.914(2) x2 } \\
\text { Ti-X(2) } 1.872(3) \times 4\end{array}$ & [78] \\
\hline 91 & $\mathrm{Rb}_{2} \mathrm{KTiOF}_{5} \quad 218 \mathrm{~K}$ & $\begin{array}{l}\text { Ti-F(1) 2.072(3) } \\
\text { Ti-F(1A) } 1.915(2) \times 4 \\
\text { Ti-O(1) } 1.744(3)\end{array}$ & [78] \\
\hline 92 & $\left(\mathrm{NH}_{4}\right)_{3} \mathrm{TiOF}_{5}$ & \begin{tabular}{|l|} 
Ti-F(1) 2.017(3) \\
Ti-F(2)1.897(3) x4 \\
Ti-O(1) 1.695(3) \\
\end{tabular} & {$[78]$} \\
\hline 93 & $\left(\mathrm{NH}_{4}\right)_{3} \mathrm{TiOF}_{5}$ & $\operatorname{Ti}(\mathrm{O}, \mathrm{F}) 1.878(1) \times 6$ & [79] \\
\hline 94 & $\left(\mathrm{C}_{7} \mathrm{H}_{9} \mathrm{NH}\right)\left[\mathrm{TiF}_{5}\left(\mathrm{H}_{2} \mathrm{O}\right)\right]$ & $\begin{array}{l}\text { 1.7865(12)-1.8590(14) } \\
\text { Ti-Ow 2.1151(17) }\end{array}$ & [38] \\
\hline 95 & $\left(\mathrm{C}_{4} \mathrm{H}_{10} \mathrm{~N}_{2} \mathrm{H}_{2}\right)\left[\mathrm{TiF}_{5}\left(\mathrm{H}_{2} \mathrm{O}\right)\right]_{2}$ & \begin{tabular}{|l}
$1.7992(19)-1.855(2)$ \\
Ti-Ow 2.084(3) \\
\end{tabular} & [80] \\
\hline \multicolumn{4}{|c|}{ Dimeric structures } \\
\hline 66 & \begin{tabular}{|l}
$\left(\mathrm{NMe}_{4}\right)_{4}\left[\mathrm{Ti}(1)_{2} \mathrm{~F}_{11}\right]$ \\
{$\left[\mathrm{Ti}(2)_{2} \mathrm{~F}_{9}\left(\mathrm{H}_{2} \mathrm{O}\right)_{2}\right]$} \\
$\operatorname{Ti}(2)$
\end{tabular} & \begin{tabular}{|l|}
$1.737(4)-1.839(2)$ \\
$1.9927(1)$ \\
$\operatorname{Ti}(2)-02.1252(16)$ \\
\end{tabular} & [64] \\
\hline 96 & \begin{tabular}{|l}
$\left(\mathrm{C}_{4} \mathrm{H}_{10} \mathrm{~N}_{2} \mathrm{H}_{2}\right)_{2}\left[\mathrm{Ti}_{2} \mathrm{~F}_{10} \mathrm{O}\right]$ \\
$-2 \mathrm{H}_{2} \mathrm{O}$ \\
$\mathrm{Ti}(1)$ \\
$\operatorname{Ti}(2)$ \\
\end{tabular} & $\begin{array}{l}\frac{1.844(2)-1.964(2)}{T i-O \quad 1.803(2)} \\
\frac{1.846(2)-1.967(2)}{T i-O \quad 1.812(2))} \\
\end{array}$ & [81] \\
\hline 97 & $\begin{array}{l}\left(\mathrm{C}_{10} \mathrm{H}_{12} \mathrm{Se}_{4}\right)_{3} \\
{\left[\mathrm{Ti}_{2} \mathrm{~F}_{8}\left(\mathrm{C}_{2} \mathrm{O}_{4}\right)\right]} \\
\left(\left(\mathrm{TMTSF}_{3}\left[\mathrm{Ti}_{2} \mathrm{~F}_{8}\left(\mathrm{C}_{2} \mathrm{O}_{4}\right)\right]\right)\right.\end{array}$ & $\frac{1.771(5)-1.823(5)}{\text { Ti-O 2.112(6), 2.133(6) }}$ & [82] \\
\hline \multicolumn{4}{|c|}{ Chain structures } \\
\hline 98 & $\left(\mathrm{C}_{4} \mathrm{H}_{12} \mathrm{~N}_{2} \mathrm{H}_{2}\right)\left[\mathrm{TiF}_{4} \mathrm{O}\right]$ & $\frac{1.888(2)-1.919(2)}{T i-O 2.0329(3) \times 2}$ & [83] \\
\hline 99 & $\begin{array}{l}\left(\mathrm{enH}_{2}\right)\left(\mathrm{TiOF}_{4}\right) \\
\mathrm{Ti}(1) \\
\operatorname{Ti}(2)\end{array}$ & $\begin{array}{l}\frac{1.894(2) \times 4}{T i-O 2.010(1) \times 2} \\
\frac{1.919(3) \times 4}{T i-O 1.690(5), 2.330(5)}\end{array}$ & [84] \\
\hline
\end{tabular}




\begin{tabular}{|c|c|c|c|}
\hline \multicolumn{4}{|c|}{ Layered structure } \\
\hline 100 & $\begin{array}{l}{\left[\mathrm{C}\left(\mathrm{NH}_{2}\right)_{3}\right]_{2}\left(\mathrm{Ti}_{5} \mathrm{O}_{5} \mathrm{~F}_{12}\right)} \\
\operatorname{Ti}(1) \\
\operatorname{Ti}(2)\end{array}$ & \begin{tabular}{|l}
$1.856(1)-1.957(1)$ \\
$\operatorname{Ti}(1)-\mathrm{O}(1) 1.843(1)$, \\
$1.958(1)$ \\
$\frac{1.952(1) \times 4}{\operatorname{Ti}(2)-\mathrm{O}(2) 1.699(1),}$ \\
$2.103(1)$
\end{tabular} & {$[85]$} \\
\hline \multicolumn{4}{|c|}{ Hydroxyfluoridotitanates(IV) } \\
\hline 101 & $\left(\mathrm{C}_{2} \mathrm{H}_{5} \mathrm{~N}_{5} \mathrm{H}\right)_{2}\left[\mathrm{TiF}_{4.9}(\mathrm{OH})_{1.1}\right]$ & \begin{tabular}{|l|} 
Ti-(F, OH) \\
$1.841(2)-1.868(2)$
\end{tabular} & {$[86]$} \\
\hline 102 & $\left(\mathrm{C}_{2} \mathrm{H}_{5} \mathrm{~N}_{5} \mathrm{H}_{2}\right)\left[\mathrm{TiF}_{4.8}(\mathrm{OH})_{1.2}\right]$ & $\begin{array}{l}\text { Ti-(F, OH) } \\
1.816(2)-1.893(2)\end{array}$ & [86] \\
\hline 103 & $\left(\mathrm{enH}_{2}\right)\left[\mathrm{TiF}_{4.3}(\mathrm{OH})_{1.7}\right]$ & $\begin{array}{l}\text { Ti-(F, OH) } \\
1.845(3)-1.855(2\end{array}$ & [86] \\
\hline 104 & $\begin{array}{l}\left(\operatorname{dienH}_{2}\right)\left[\mathrm{Ti}(\mathrm{F}, \mathrm{OH})_{6}\right] \\
\cdot 2 \mathrm{H}_{2} \mathrm{O}\end{array}$ & $\begin{array}{l}\text { Ti-(F, OH) } \\
1.824(3)-1.887(3)\end{array}$ & [86] \\
\hline 105 & $\begin{array}{l}\left(\text { tren } \mathrm{H}_{4}\right)\left(\mathrm{TiF}_{4.6}(\mathrm{OH})_{1.4}\right)_{2} \\
\cdot 2.7 \mathrm{H}_{2} \mathrm{O}\end{array}$ & $\begin{array}{l}\text { Ti(1)-Ti(6)- (F, OH) } \\
1.811(4)-1.896(3)\end{array}$ & [137] \\
\hline 106 & $\begin{array}{l}\beta- \\
\left(\operatorname{tren} \mathrm{H}_{3}\right)\left(\mathrm{TiF}_{4.5}(\mathrm{OH})_{1.5}\right)(\mathrm{F})\end{array}$ & $\begin{array}{l}\text { Ti(1)-(F, OH) 1.891(7) } \\
\text { Ti(2)-(F, OH) } 1.820(5)\end{array}$ & [137] \\
\hline 107 & $\alpha-\left(\operatorname{tren} \mathrm{H}_{3}\right)\left(\mathrm{TiF}_{4.7}(\mathrm{OH})_{1.3}\right)(\mathrm{F})$ & $\begin{array}{l}\text { Ti(1)-(F, OH) 1.796(3)- } \\
1.882(3) \\
\operatorname{Ti}(2)-(\mathrm{F}, \mathrm{OH}) 1.803(3)- \\
1.856(3)\end{array}$ & [137] \\
\hline \multicolumn{4}{|c|}{ Structures of peroxofluoride complexes of titanium(IV) } \\
\hline \multicolumn{4}{|c|}{ Monomeric structures } \\
\hline 108 & $\left(\mathrm{NH}_{4}\right)_{3}\left[\mathrm{Ti}\left(\mathrm{O}_{2}\right) \mathrm{F}_{5}\right]$ & \begin{tabular}{|l|} 
Ti-(O, F)(1) $1.938(14)$ \\
Ti-(O. F)(2) $1.959(39)$
\end{tabular} & [87] \\
\hline 109 & $\left(\mathrm{NH}_{4}\right)_{3}\left[\mathrm{Ti}\left(\mathrm{O}_{2}\right) \mathrm{F}_{5}\right]$ & $\begin{array}{l}\text { Ti-F 1.91(1) x5 } \\
\text { Ti-O } 1.82\end{array}$ & [88] \\
\hline 110 & $\left(\mathrm{NH}_{4}\right)_{3}\left[\mathrm{Ti}\left(\mathrm{O}_{2}\right) \mathrm{F}_{5}\right]$ & $\begin{array}{l}\text { Ti-F } 1.881(6) \times 5 \\
\text { Ti-O } 1.902(17)\end{array}$ & [89] \\
\hline 111 & $\left(\mathrm{NH}_{4}\right)_{3}\left[\mathrm{Ti}\left(\mathrm{O}_{2}\right) \mathrm{F}_{5}\right]$ & \begin{tabular}{|l|l} 
Ti-F(1) & $1.913(8)$ \\
Ti-F(2) & $1.928(36)$ \\
Ti-O $1.965(14)$
\end{tabular} & {$[90]$} \\
\hline 112 & $\mathrm{~K}_{3}\left[\mathrm{Ti}\left(\mathrm{O}_{2}\right) \mathrm{F}_{5}\right]$ & \begin{tabular}{|l|} 
Ti-F(1) $1.894(5)$ \\
Ti-F(2) 1.88 \\
Ti-O 1.98(2)
\end{tabular} & [91] \\
\hline 113 & $\mathrm{Ba}_{3}\left[\mathrm{Ti}\left(\mathrm{O}_{2}\right) \mathrm{F}_{5}\right]_{2} \cdot 2 \mathrm{H}_{2} \mathrm{O}$ & $\begin{array}{l}1.969(8)-2.090(8) \\
\text { Ti-O 1.900(9) }\end{array}$ & [92] \\
\hline 114 & $\mathrm{~K}_{3}\left[\mathrm{Ti}\left(\mathrm{O}_{2}\right)_{2} \mathrm{~F}_{3}\right] \quad 300 \mathrm{~K}$ & \begin{tabular}{|l|}
$1.890(9)-1.979(12)$ \\
Ti-O(1) $1.896(4)$ \\
Ti-O(2) $1.950(4)$
\end{tabular} & [93] \\
\hline
\end{tabular}




\begin{tabular}{|c|c|c|c|}
\hline 115 & $\mathrm{~K}_{3}\left[\mathrm{Ti}\left(\mathrm{O}_{2}\right)_{2} \mathrm{~F}_{3}\right] 120 \mathrm{~K}$ & \begin{tabular}{|l}
$1.895(2)-1.973(3)$ \\
Ti-O(1) $1.895(2)$ \\
Ti-O(2) $1.959(2)$
\end{tabular} & {$[94]$} \\
\hline \multicolumn{4}{|c|}{ Dimeric structures } \\
\hline 116 & $\mathrm{~K}_{2} \mathrm{Ti}\left(\mathrm{O}_{2}\right) \mathrm{F}_{4} \cdot \mathrm{H}_{2} \mathrm{O}$ & \begin{tabular}{|l|}
$1.884(1)-1.943(1)$ \\
$2.028(1), 2.132(1)$ \\
Ti-O(1) $1.868(1)$ \\
Ti-O(2) $1.865(1)$
\end{tabular} & [95] \\
\hline 117 & $\mathrm{~K}_{2} \mathrm{Ti}\left(\mathrm{O}_{2}\right) \mathrm{F}_{4} \cdot 0.5 \mathrm{H}_{2} \mathrm{O}$ & $\begin{array}{l}\frac{1.889(1)-1.946(1)}{2.027(3), 2.106(2)} \\
\text { Ti-O(1) } 1.869(3) \\
\text { Ti-O(2) } 1.905(2)\end{array}$ & [96] \\
\hline 118 & $\mathrm{~K}_{4}\left[\mathrm{Ti}_{2}\left(\mathrm{O}_{2}\right)_{2} \mathrm{~F}_{8}\right] \cdot \mathrm{H}_{2} \mathrm{O}_{2}$ & \begin{tabular}{|l}
$\frac{1.881(2)-1.943(2)}{2.026(2), 2.110(2)}$ \\
Ti-O(1) $1.895(3)$ \\
Ti-O(2) $1.865(3)$
\end{tabular} & {$[97]$} \\
\hline 119 & $\mathrm{~K}_{2} \mathrm{Na}_{2}\left[\mathrm{Ti}_{2}\left(\mathrm{O}_{2}\right)_{2} \mathrm{~F}_{8}\right] \cdot \mathrm{H}_{2} \mathrm{O}$ & $\begin{array}{l}\frac{1.878(6)-1.951(2)}{2.050(2), 2.133(2)} \\
\text { Ti-O(1) } 1.850(2) \\
\text { Ti-O(2) } 1.857(2)\end{array}$ & [98] \\
\hline
\end{tabular}

*Range of Ti-F and Ti-O bond distances: the values for the terminal bonds are shown above the horizontal line, while the corresponding values for the bridging bonds are shown in italic below the horizontal line. 


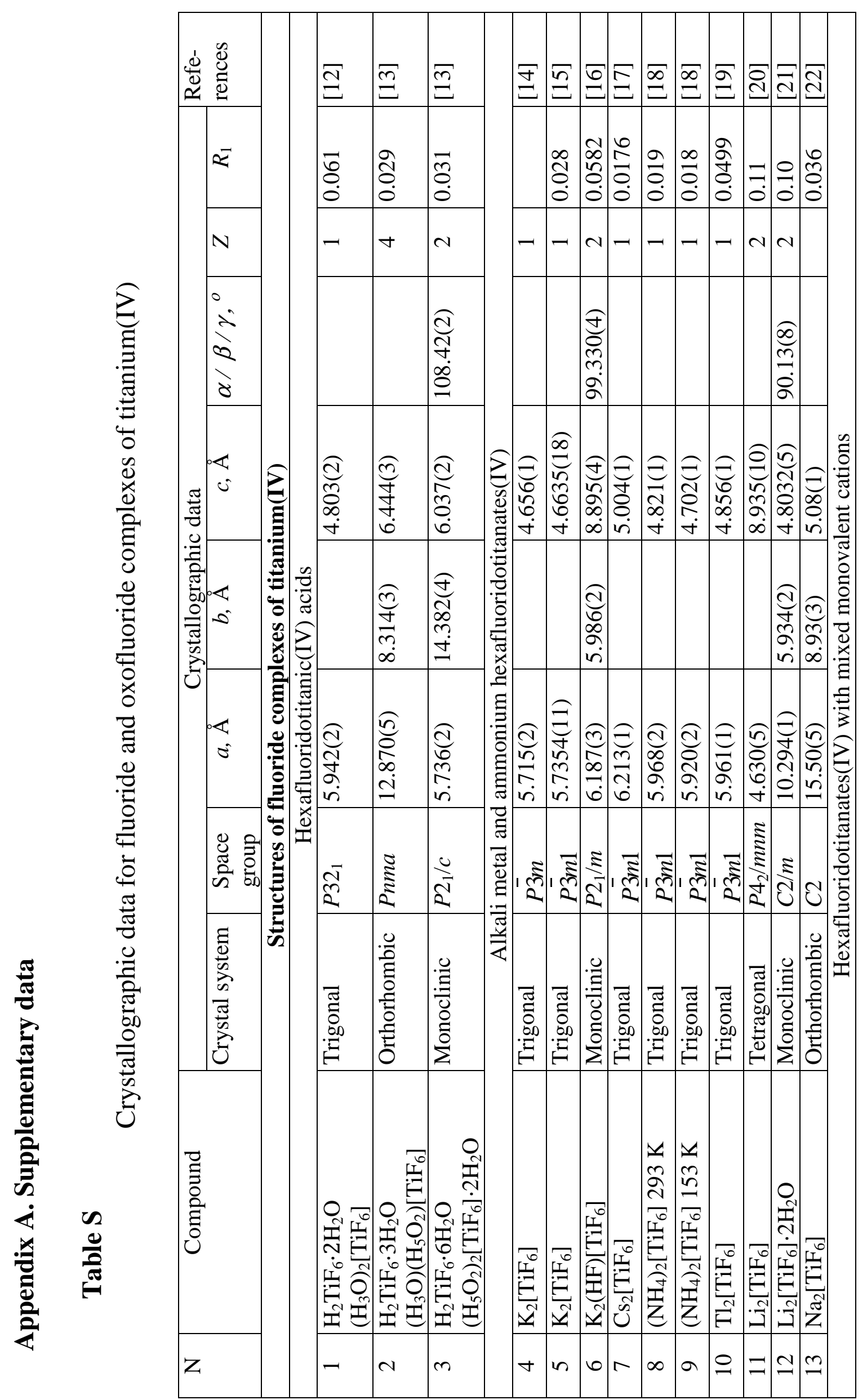




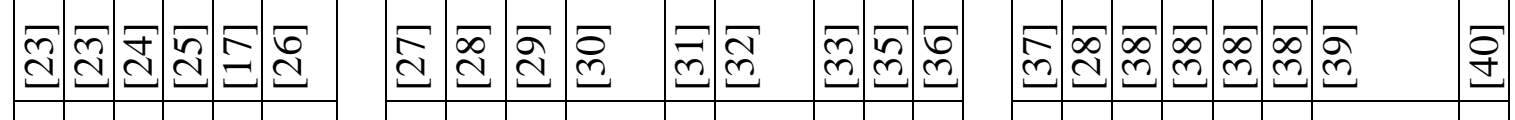

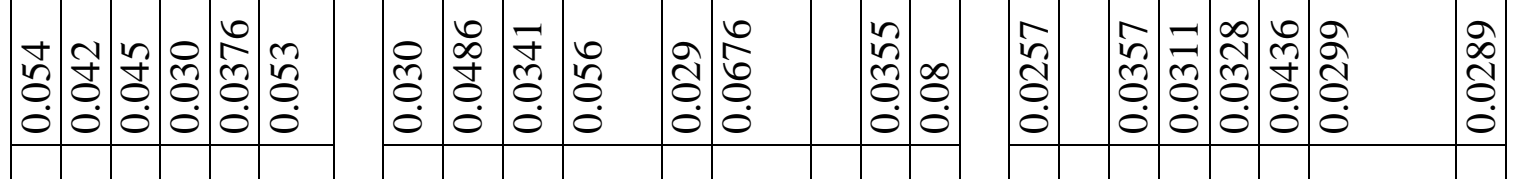

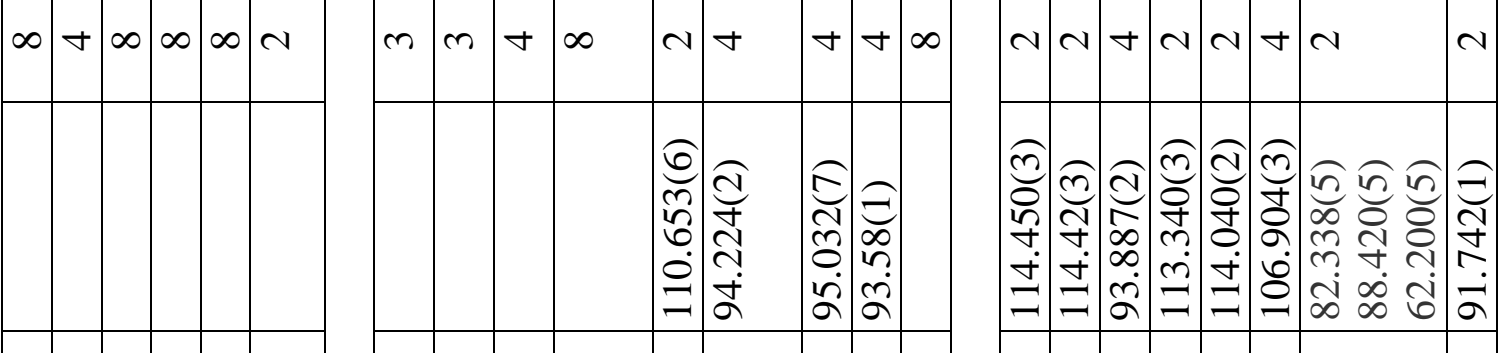

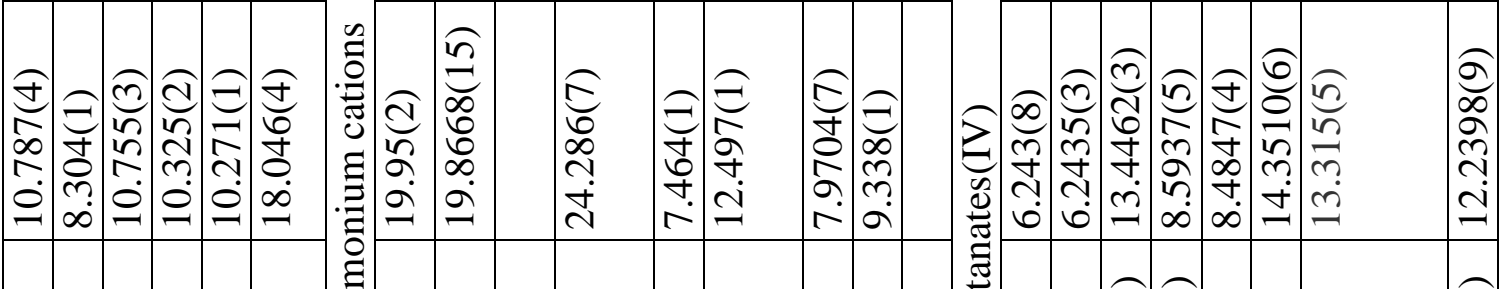

ชิฮิฮิ ฮิ

త্তে

क

i $\underset{j}{i} \dot{I}$

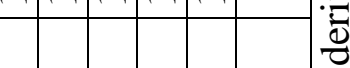

ণ่

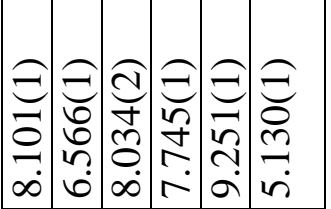

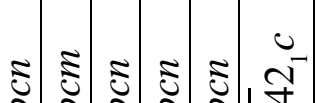

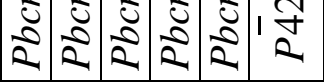

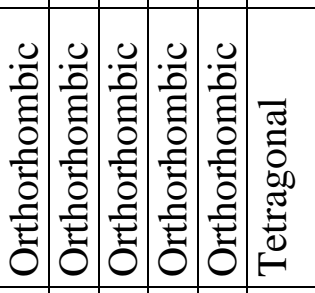

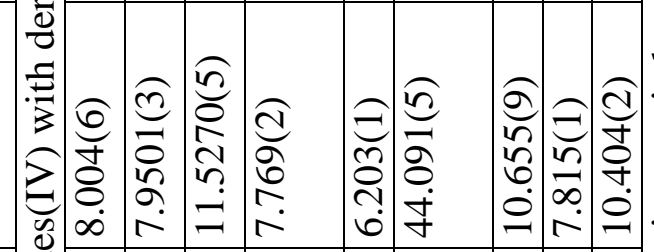

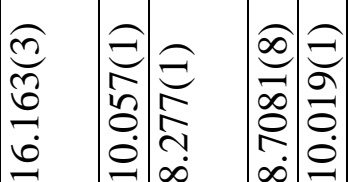

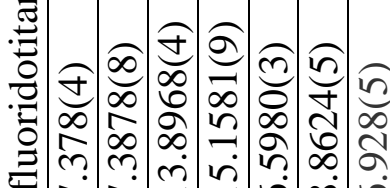

ڤัฒ

离

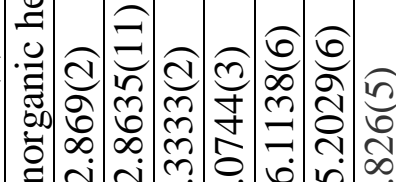

6

i ç 0 in

$=-r=0$

. ज्ञ

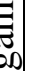

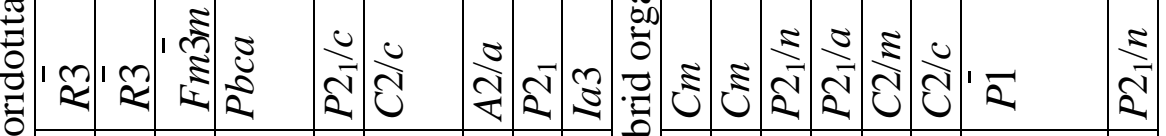

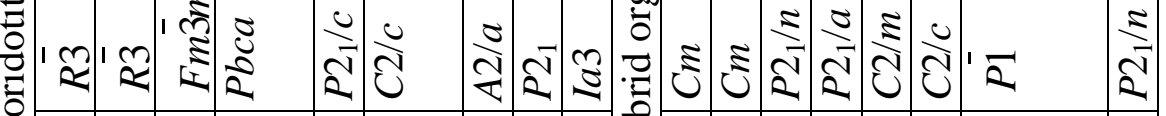

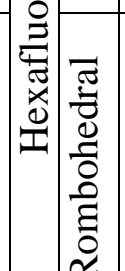

षQ

空

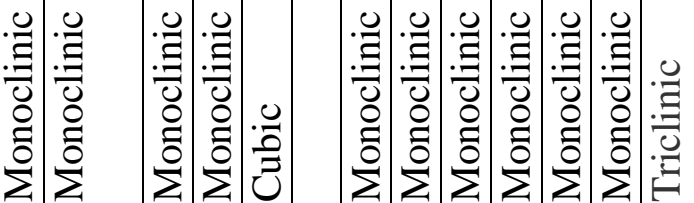

:

$\approx$ U

7
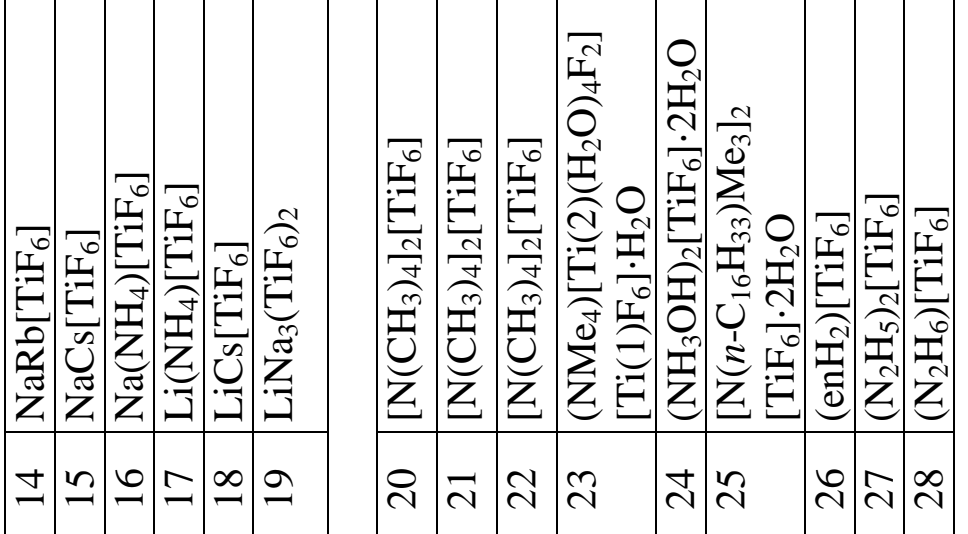

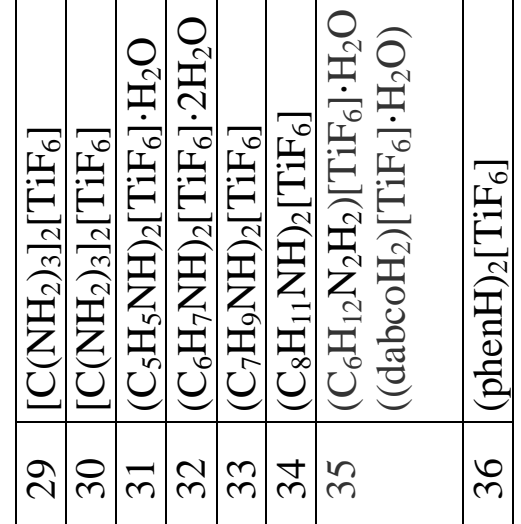




\begin{tabular}{|c|c|c|c|c|c|c|c|c|c|c|c|c|c|c|c|c|c|c|c|c|c|}
\hline$\Xi$ & 竎 & & $\underset{\Xi}{ \pm}$ & $\underset{\Xi}{ \pm}$ & 导 & $\underset{\Omega}{\Xi}$ & 它 & 于 & $\underset{ \pm}{ \pm}$ & 守 & 을 & $\bar{\Xi}$ & & 壳 & $\begin{array}{l}\tilde{n} \\
\tilde{n}\end{array}$ & 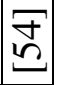 & in & 谄 & {$\left[\begin{array}{l}n \\
n \\
n\end{array}\right.$} & 苞 & $\sqrt{n}$ \\
\hline $\begin{array}{l}\sim \\
\infty \\
\infty \\
0 \\
0\end{array}$ & 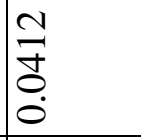 & & 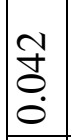 & Oે & ठ் & $\begin{array}{l}\infty \\
\infty \\
0 \\
0\end{array}$ & $\begin{array}{l}\bar{n} \\
\tilde{0} \\
0 \\
0\end{array}$ & $\begin{array}{l}\infty \\
0 \\
0 \\
0\end{array}$ & $\begin{array}{c}2 \\
\infty \\
0 \\
0 \\
0\end{array}$ & స̂. & ঠิ & $\begin{array}{l}\stackrel{1}{ } \\
0 \\
0 \\
0\end{array}$ & & 旾 & $\begin{array}{l}0 \\
\stackrel{0}{0}\end{array}$ & 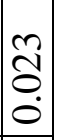 & $\overline{0}$ & 号 & $\mid \begin{array}{l}\bar{n} \\
0 \\
0 \\
\end{array}$ & $\begin{array}{l}8 \\
8 \\
0 \\
0\end{array}$ & $\mid \begin{array}{l}1 \\
0 \\
0 \\
0\end{array}$ \\
\hline$\nabla$ & - & & $m$ & $m$ & $m$ & $m$ & 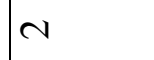 & $\sim$ & $\nabla$ & $\nabla$ & $\nabla$ & $N$ & & $\nabla$ & $\sim \mid$ & $\nabla$ & $N$ & $\checkmark$ & $N \mid$ & $\nabla$ & $N$ \\
\hline 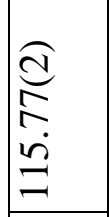 & 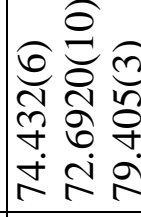 & & & & & & 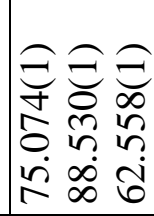 & 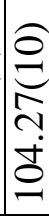 & $\begin{array}{l}0 \\
a \\
2 \\
2 \\
2 \\
11 \\
2\end{array}$ & $\begin{array}{l}\text { d } \\
\text { m} \\
2 \\
2 \\
\text { II } \\
2\end{array}$ & 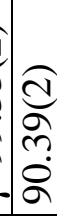 & & & & & & .0 & & & $\begin{array}{l}\overparen{\Xi} \\
\text { } \\
\varrho\end{array}$ & 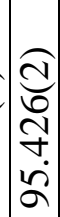 \\
\hline 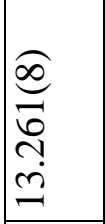 & 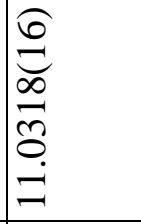 & $\geq$ & \begin{tabular}{|l}
$\mathcal{\Xi}$ \\
$\infty$ \\
2 \\
0 \\
0 \\
0
\end{tabular} & 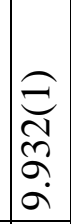 & 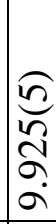 & 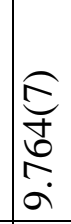 & 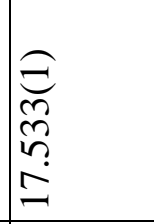 & 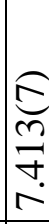 & $\begin{array}{l}\overparen{J} \\
\curvearrowright \\
\infty \\
\sigma \\
\sigma\end{array}$ & $\begin{array}{l}\overparen{J} \\
n \\
n \\
\sigma \\
\sigma\end{array}$ & 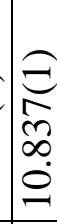 & 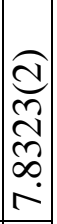 & 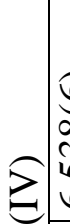 & $\begin{array}{l}6 \\
\infty \\
\infty \\
n \\
n \\
0\end{array}$ & 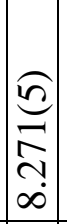 & 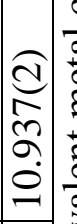 & 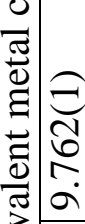 & $\begin{array}{l}3 \\
\infty \\
\infty \\
\infty \\
-\end{array}$ & 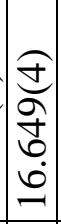 & 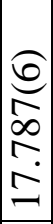 & 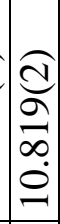 \\
\hline 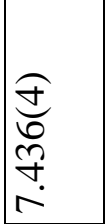 & 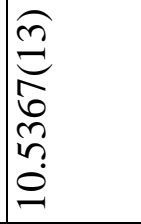 & 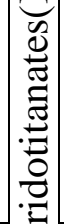 & & & & & 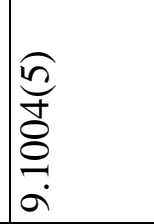 & 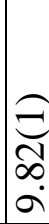 & 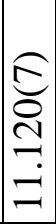 & 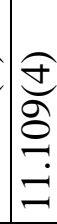 & $\begin{array}{l}\varrho \\
\infty \\
\infty \\
0 \\
r\end{array}$ & 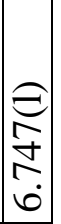 & 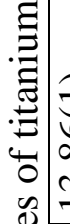 & $\begin{array}{l}Ð \\
ٍ \\
\infty \\
\dot{\infty}\end{array}$ & & 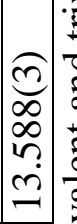 & 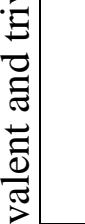 & 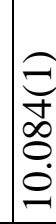 & & 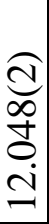 & $\begin{array}{l}\overparen{\Xi} \\
2 \\
\infty \\
0 \\
0\end{array}$ \\
\hline $\begin{array}{l}\infty \\
\stackrel{\infty}{m} \\
\stackrel{m}{+} \\
\dot{ \pm}\end{array}$ & 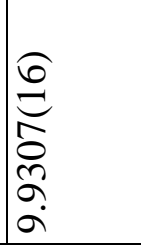 & 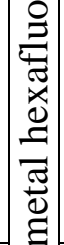 & 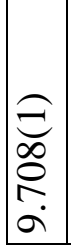 & 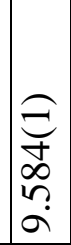 & $\begin{array}{l}\mathcal{J} \\
n \\
\infty \\
n \\
\sigma\end{array}$ & 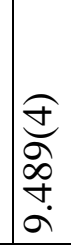 & 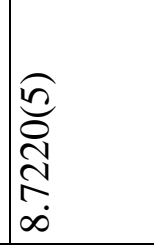 & $\begin{array}{l}\text { ñ } \\
8 \\
\text { ? } \\
n\end{array}$ & 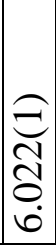 & 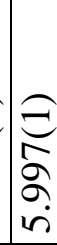 & 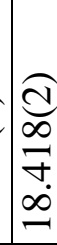 & $\begin{array}{l}\widehat{O} \\
\Xi \\
= \\
\Xi \\
\Xi\end{array}$ & 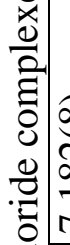 & 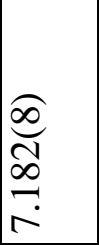 & 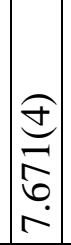 & 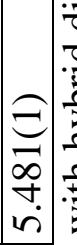 & 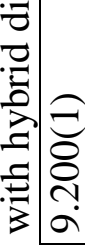 & 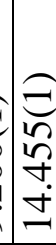 & \begin{tabular}{|c|}
$\widehat{\bigcup}$ \\
$\infty$ \\
$\infty$ \\
0 \\
0 \\
0 \\
\end{tabular} & 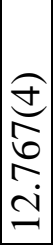 & 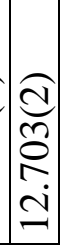 \\
\hline ते & $\bar{\Omega}$ & 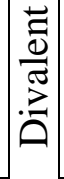 & $\begin{array}{ll}1 & 0 \\
0\end{array}$ & 12 & 10 & 2 & $\overline{2}$ & $\frac{\cup}{N}$ & $\frac{\Sigma}{\sqrt{2}}$ & $\frac{\S}{\sqrt{2}}$ & $\frac{\dot{v}}{\tilde{U}}$ & 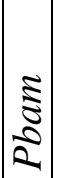 & 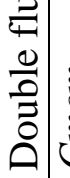 & 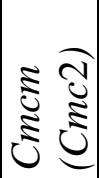 & $\frac{\Sigma}{7}$ & 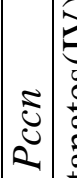 & 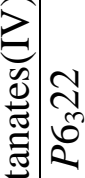 & 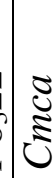 & 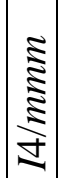 & 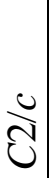 & $\frac{\mathrm{U}}{\mathrm{U}}$ \\
\hline 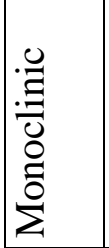 & 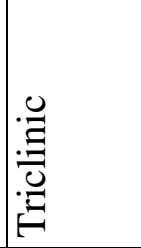 & & 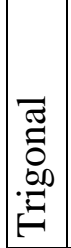 & 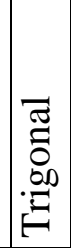 & 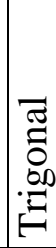 & 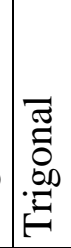 & 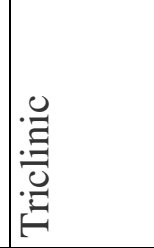 & 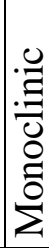 & 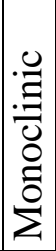 & 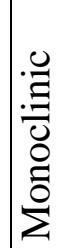 & 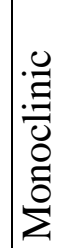 & 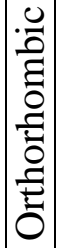 & & 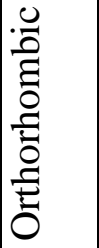 & 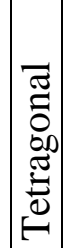 & 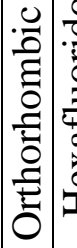 & 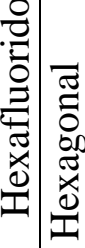 & 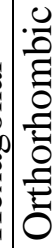 & 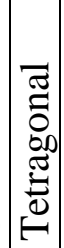 & 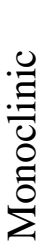 & $\begin{array}{l}\cdot 0 \\
. \Xi \\
0 \\
0 \\
0 \\
\Sigma \\
\Sigma\end{array}$ \\
\hline 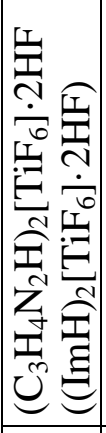 & $\frac{Z}{\sum_{0}^{Z}}$ & & 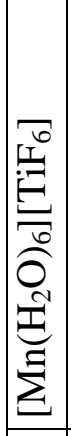 & 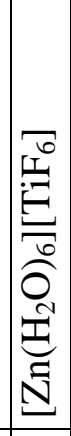 & 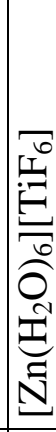 & 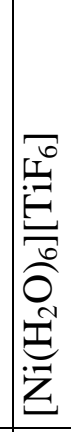 & 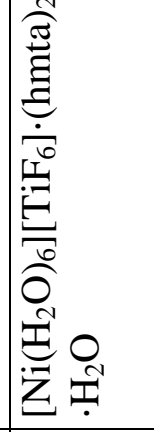 & 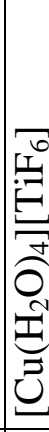 & 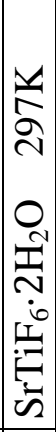 & 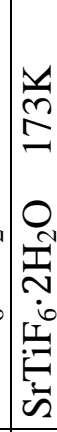 & 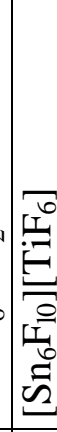 & 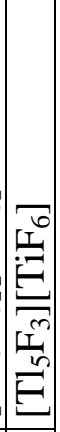 & & 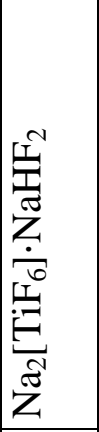 & 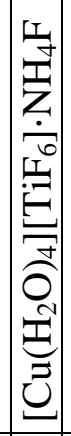 & 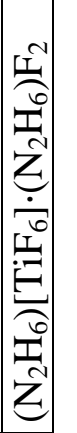 & 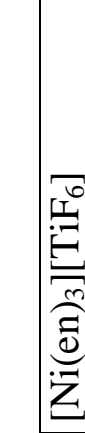 & 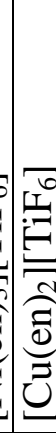 & 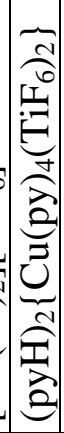 & 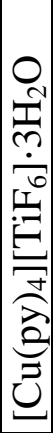 & 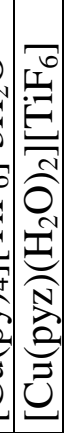 \\
\hline$\hat{m}$ & $\infty$ & & $m$ & f & $\bar{\nabla}$ & ช & $\ddot{q}$ & 寸 & $\stackrel{n}{f}$ & $\stackrel{0}{+}$ & ซ & $\stackrel{\infty}{+}$ & & $\stackrel{\vartheta}{\forall}$ & i̊ & $\bar{n}$ & in & $\tilde{i n}$ & in & $n$ & $n$ \\
\hline
\end{tabular}




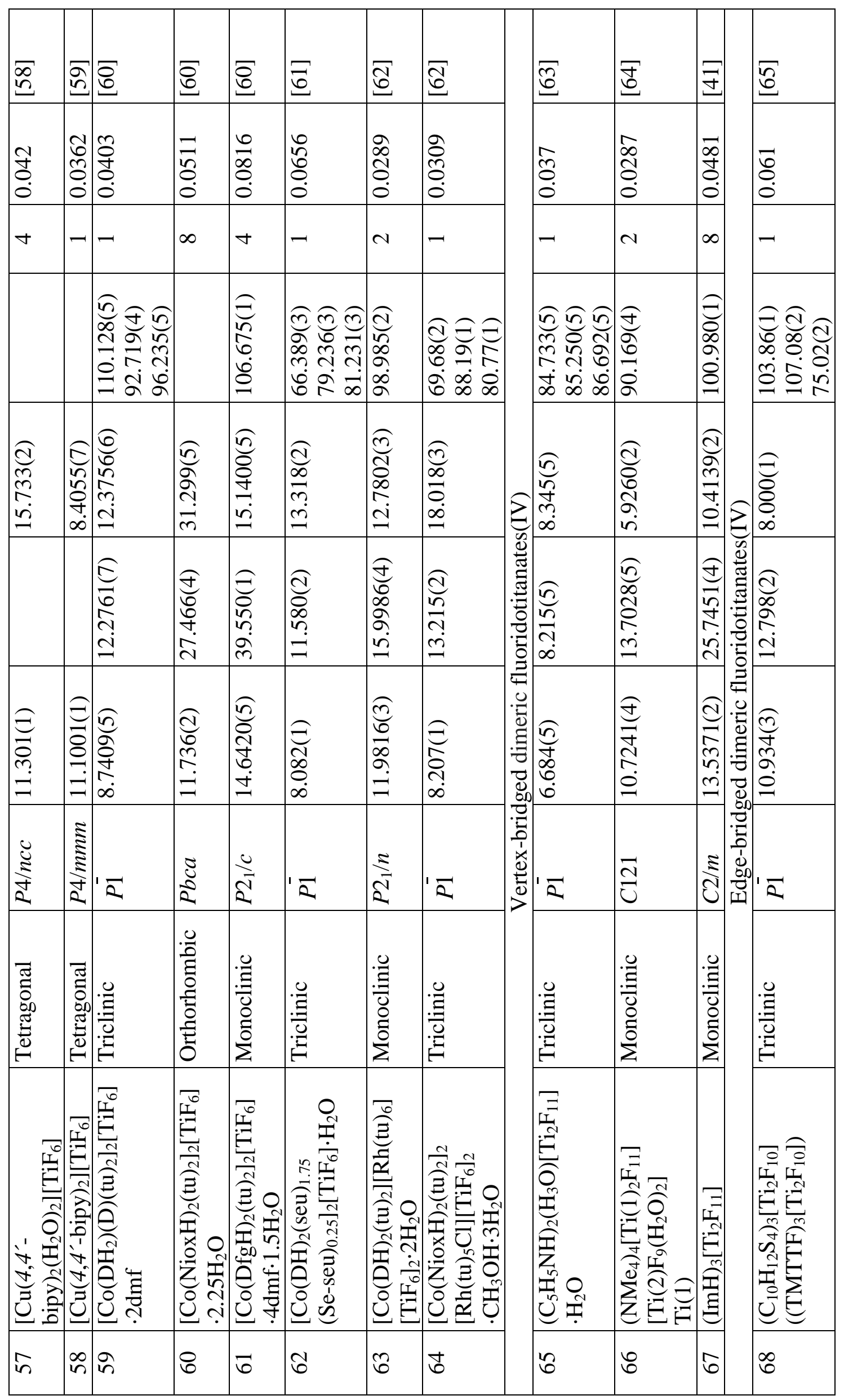




\begin{tabular}{|c|c|c|c|c|c|c|c|c|c|c|c|c|c|c|c|c|c|c|c|}
\hline ర్ర & & & 6 & 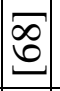 & $\infty$ & $\widehat{\theta}$ & 잉 & 寻 & $\Xi$ & $\Xi$ & $\Xi$ & $\Xi$ & & $\mathcal{N}$ & 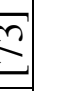 & $\underset{\infty}{\infty}$ & $\infty$ & $\exists$ & 寻 \\
\hline $\begin{array}{l}0 \\
0 \\
0 \\
0\end{array}$ & & & $\begin{array}{l}0 \\
\infty \\
0 \\
0 \\
0 \\
0\end{array}$ & $\mid \begin{array}{c}1 \\
8 \\
8 \\
0 \\
0\end{array}$ & $\begin{array}{l}n \\
n \\
0 \\
0 \\
0\end{array}$ & $\mid \begin{array}{c}n \\
\hat{0} \\
0\end{array}$ & 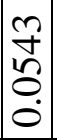 & $\begin{array}{l}\infty \\
\vdots \\
0 \\
0\end{array}$ & $\begin{array}{l}0 \\
0 \\
0 \\
0 \\
0\end{array}$ & 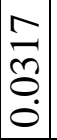 & \begin{tabular}{l}
$\tilde{n}$ \\
\multirow{0}{0}{} \\
0
\end{tabular} & 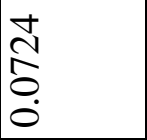 & & $\begin{array}{l}0 \\
\vdots \\
0 \\
0 \\
0\end{array}$ & & $\begin{array}{l}1 \\
0 \\
+ \\
0 \\
0\end{array}$ & $\frac{1}{8}$ & 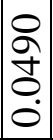 & $\begin{array}{l}n \\
n \\
6 \\
0 \\
0\end{array}$ \\
\hline$\forall$ & & & $\infty$ & $\nabla$ & $N$ & $\nabla$ & $\nabla$ & $\sim$ & - & $\nabla$ & - & - & & $\infty=$ & $\underline{0}$ & $\nabla$ & $\nabla$ & $\nabla$ & ४ \\
\hline 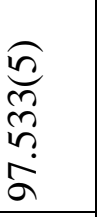 & & 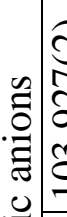 & 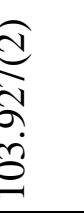 & & 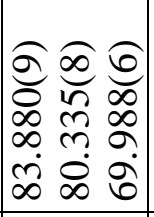 & 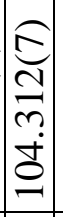 & 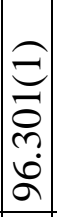 & 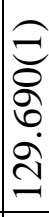 & 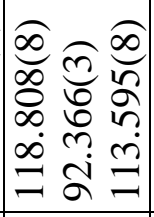 & & 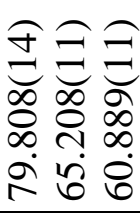 & 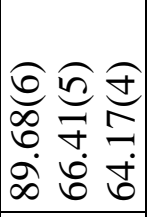 & & 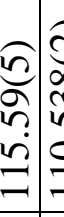 & 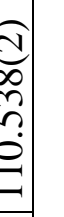 & & 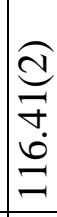 & & 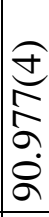 \\
\hline 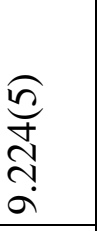 & & 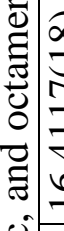 & 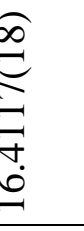 & 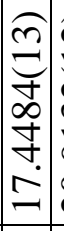 & 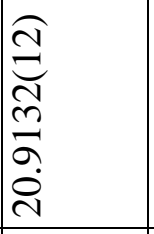 & 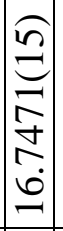 & 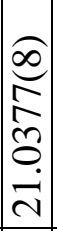 & $\begin{array}{l}\frac{\pi}{+} \\
\frac{\sigma}{2} \\
\infty \\
\infty\end{array}$ & 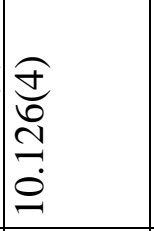 & 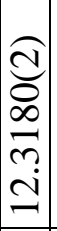 & 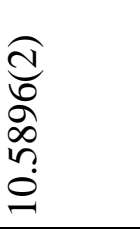 & $\begin{array}{l}\hat{\sigma} \\
\infty \\
\infty \\
\infty \\
n \\
0 \\
0 \\
\end{array}$ & & 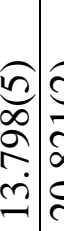 & 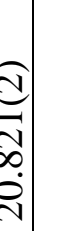 & $\begin{array}{c}6 \\
0 \\
\infty \\
\pm \\
\pm \\
\pm \\
\pm\end{array}$ & 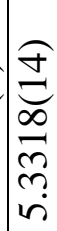 & 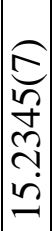 & 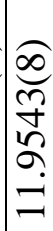 \\
\hline 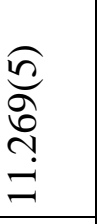 & 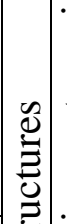 & 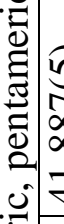 & 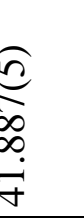 & 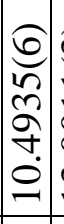 & $\begin{array}{l}\widehat{0} \\
\cdots \\
\overline{8} \\
8 \\
\ddot{2} \\
\end{array}$ & 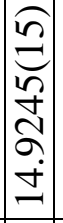 & 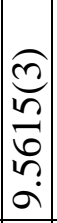 & 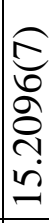 & $\begin{array}{l}\stackrel{\Xi}{\pi} \\
\hat{\sigma} \\
a\end{array}$ & 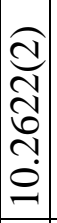 & 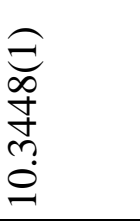 & 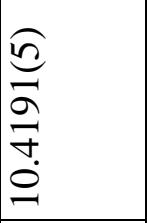 & 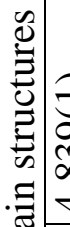 & 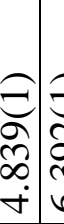 & & 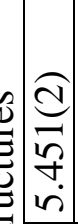 & 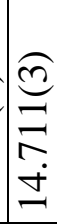 & 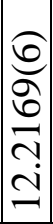 & 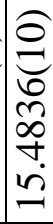 \\
\hline $\begin{array}{l}\sqrt{n} \\
n \\
\sigma \\
\infty \\
\infty \\
\infty\end{array}$ & 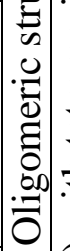 & 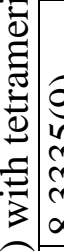 & $\begin{array}{l}\text { } \\
n \\
m \\
m \\
m \\
\infty \\
\infty \\
0\end{array}$ & 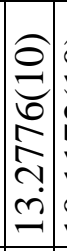 & 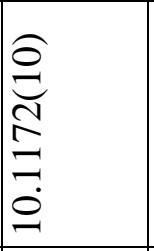 & 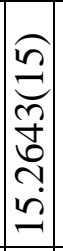 & 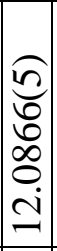 & 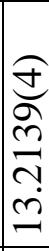 & 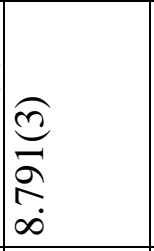 & 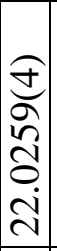 & 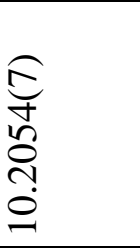 & 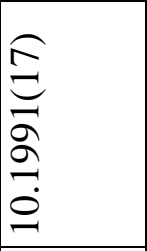 & 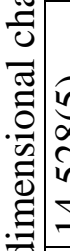 & $\begin{array}{l}\widetilde{\Xi} \\
\infty \\
\pm \\
n \\
\dot{ \pm} \\
\end{array}$ & 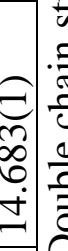 & 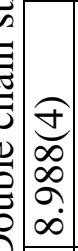 & 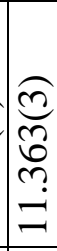 & $\begin{array}{l}\widehat{d} \\
\infty \\
\hat{\sigma} \\
\tilde{n} \\
i \\
\end{array}$ & 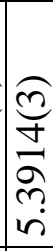 \\
\hline$\stackrel{\Sigma}{\Sigma}$ & & 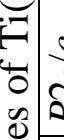 & $\begin{array}{l}u \\
\frac{u}{2} \\
2\end{array}$ & $\mid \begin{array}{r}0 \\
\vdots \\
\vdots \\
\vdots\end{array}$ & $\overline{2}$ & $\begin{array}{c}\Omega \\
\vdots \\
\Sigma\end{array}$ & $\frac{u}{\vdots}$ & $\frac{\Xi}{\mathrm{J}}$ & $\bar{Q}$ & 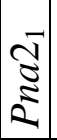 & $\bar{R}$ & $\overline{2}$ & ڤิ) & $\frac{\dot{v}}{\tilde{U}}$ & & $\begin{array}{c}\mathfrak{\Xi} \\
\vdots \\
\vdots \\
2\end{array}$ & $\frac{U}{\mathrm{U}}$ & $\begin{array}{c}\mathfrak{Z} \\
\vdots \\
\vdots \\
\mathfrak{\Sigma}\end{array}$ & $\frac{\sigma}{\sqrt{2}}$ \\
\hline 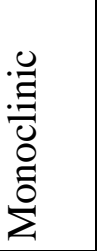 & & 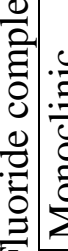 & $\begin{array}{l}0 \\
\Xi \\
0 \\
0 \\
0 \\
\vdots \\
\Sigma \\
\Sigma\end{array}$ & 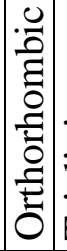 & 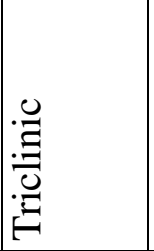 & 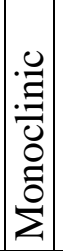 & 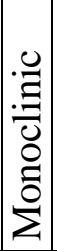 & $\begin{array}{l}.0 \\
: \Xi \\
0 \\
0 \\
0 \\
\vdots \\
\Sigma\end{array}$ & 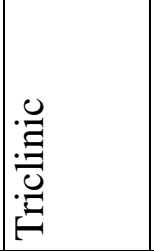 & 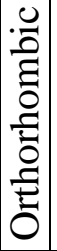 & . & 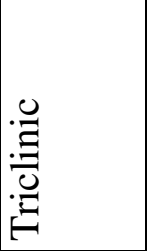 & & $\begin{array}{l}0 \\
: \\
0 \\
0 \\
0 \\
0 \\
\vdots \\
\Sigma\end{array}$ & $\begin{array}{l}0 \\
\vdots \\
\vdots \\
0 \\
\vdots \\
\vdots \\
\Sigma \\
\Sigma\end{array}$ & 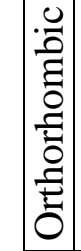 & 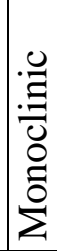 & 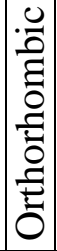 & 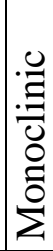 \\
\hline 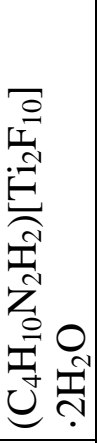 & & & 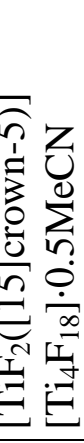 & 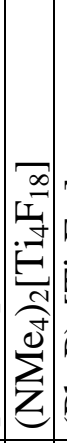 & 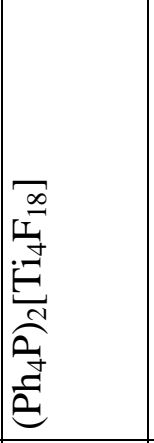 & 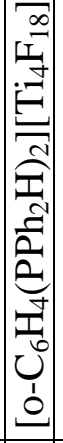 & 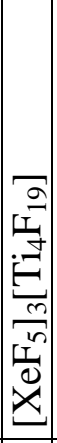 & 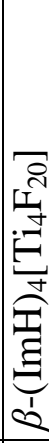 & 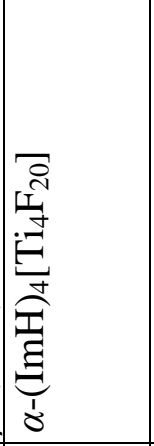 & 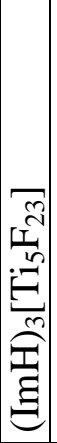 & 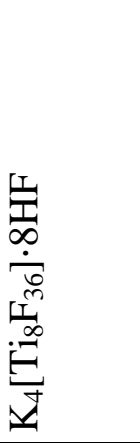 & 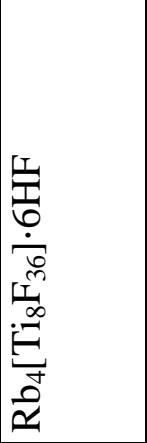 & & 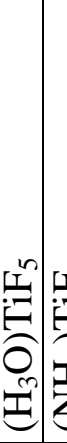 & 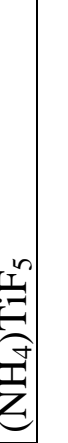 & 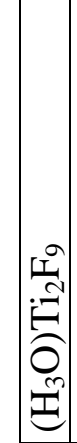 & 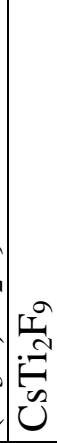 & 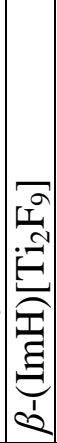 & 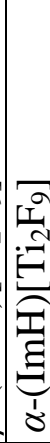 \\
\hline J్ & & & 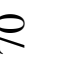 & $\bar{N}$ & $\stackrel{N}{N}$ & $\stackrel{2}{\sim}$ & 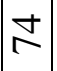 & $\stackrel{n}{r}$ & 2 & $\approx$ & $\stackrel{\infty}{\sim}$ & 2 & & $\infty$ & $\infty$ & $\infty$ & $\infty$ & ষ & $\infty$ \\
\hline
\end{tabular}




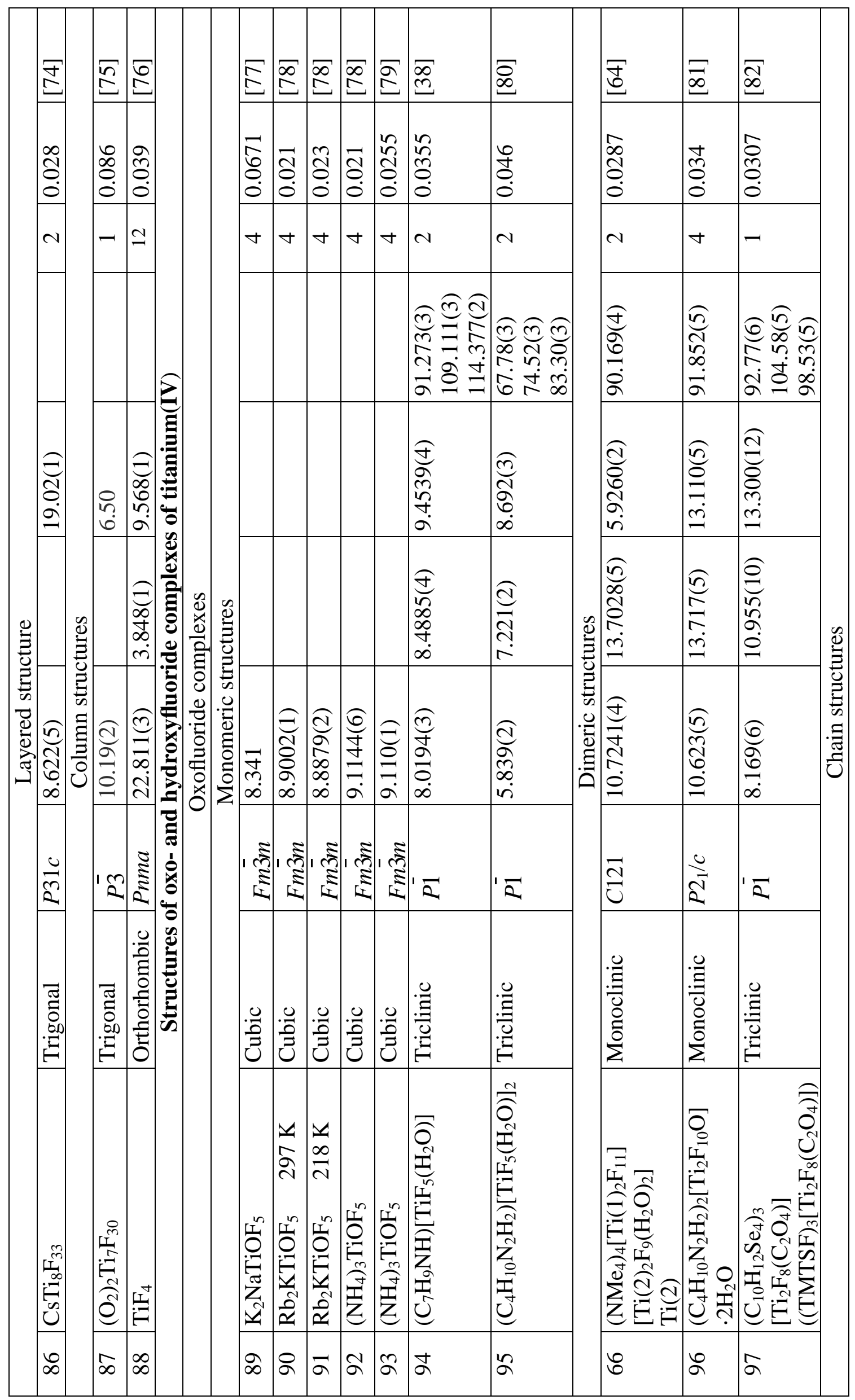




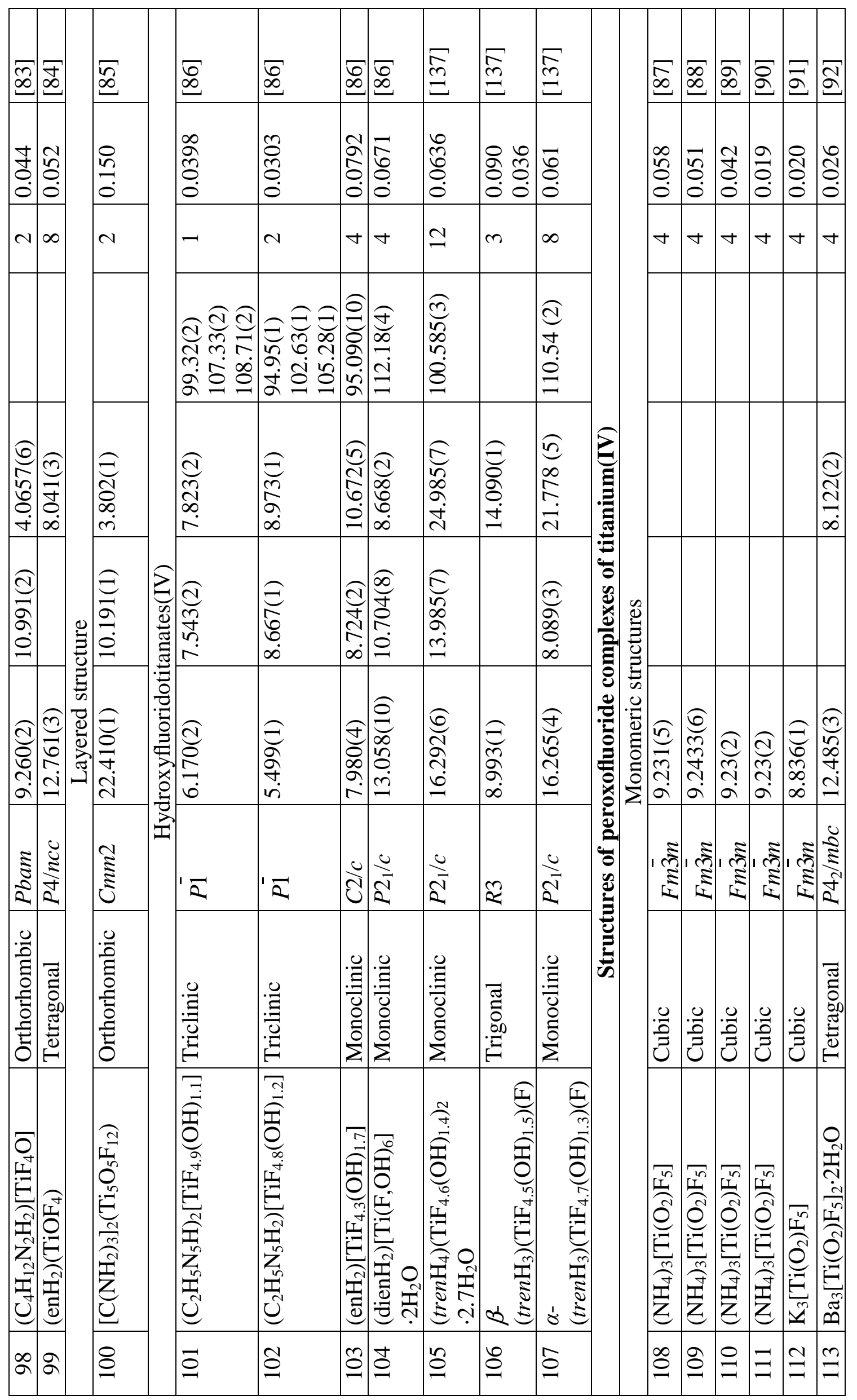




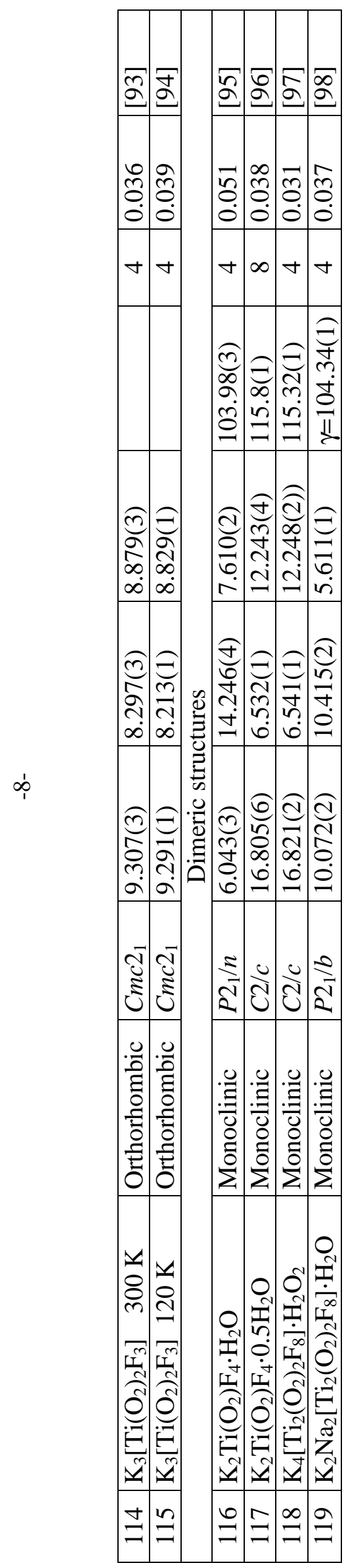

